\title{
Dinoflagellate cysts and acritarchs from the Oligocene-Lower Miocene interval of the Alma-1X well, Danish North Sea
}

\author{
POUL SCHIØLER \\ Geological Survey of Denmark and Greenland, Øster Voldgade 10, 1350 Copenhagen, Denmark (e-mail: pos@geus.dk)
}

\begin{abstract}
This palynological study of cuttings samples from the Lark Formation in the Danish North Sea well Alma-1X documents for the first time in the public domain the succession of last occurrences of dinoflagellate cysts and acritarchs in the Oligocene-Lower Miocene interval of the Central North Sea. The distribution of dinoflagellates and acritarchs in the well demonstrates the potential for the development of a detailed subdivision of the Oligocene-Lower Miocene in the Central North Sea, based on the first downhole occurrences of key taxa. Five regional intra-Lark Formation seismic and petrophysical log markers can be dated with precision using dinoflagellate biostratigraphy. Four new species and one new subspecies of dinoflagellates are described from the study interval: Amphorosphaeridium? almae sp. nov., Filisphaera pachyderma sp. nov., Pentadinium corium sp. nov., Spiniferites pseudofurcatus verrucosus ssp. nov. and Thalassiphora rota sp. nov. Pseudospiniferites manumii Lund, 2002 is emended and transferred to the genus Spiniferites. J. Micropalaeontol. 24(1): 1-37, May 2005.
\end{abstract}

KEYWORDS: Oligocene, Miocene, biostratigraphy, dinoflagellate cysts, North Sea

\section{INTRODUCTION}

Recent oil discoveries within Palaeogene sandstones in the Danish North Sea sector have sparked interest in the Palaeogene stratigraphy of this area. The present study is a part of a larger stratigraphical project on the Palaeogene sediments of the North Sea carried out by the Geological Survey of Denmark and Greenland (GEUS). The aim of the project is to improve understanding of the distribution and geometry of the Palaeogene sediment package, in particular its sandstone units, and to revise the lithostratigraphical subdivision of the siliciclastic succession above the Upper Cretaceous-Danian chalks. The project integrates seismic and log interpretations with an improved biostratigraphy from new studies of the organicwalled dinoflagellate cyst (hereafter dinoflagellate) and acritarch succession.

This study documents for the first time in the public domain the dinoflagellate and acritarch assemblage in the Oligocene through Lower Miocene interval from a Central North Sea well. Previously published stratigraphical and taxonomic studies that document the phytoplankton succession from the OligoceneLower Miocene interval in the greater North Sea Basin, include Gerlach (1961), Benedek (1972), Liengjarern et al. (1980), Piasecki (1980), De Coninck (1986, 1999, 2001), HeilmannClausen \& Costa (1989), Köthe (1990), Strauss \& Lund (1992), Powell (1992), Pross (1997), Dybkjær \& Rasmussen (2000) and Strauss et al. (2001). However, none of these studies incorporated borehole data from the present North Sea which is the aim of this contribution.

The onshore Palaeogene succession at the margins of the basin has large stratigraphical gaps caused by periods of nondeposition and/or erosion (Michelsen et al., 1998). This is particularly true for post-Eocene strata and probably reflects the effects of glacio-eustatic sea-level changes as a response to climatic changes (Zachos et al., 2001). In order to document a more comprehensive picture of the Oligocene-Lower Miocene dinoflagellate and acritarch assemblages, it is necessary to incorporate data from the central and deeper part of the North
Sea Basin where the stratigraphy is more complete. The Alma-1X well is located in such a setting - in the southern part of the Danish Central Graben (UTM 31 E $639612 \mathrm{~m} \mathrm{~N}$ $6150851 \mathrm{~m}$, Fig. 1). Although not entirely free of unconformities, Alma $1 \mathrm{X}$ provides a more complete picture of the phytoplankton assemblages of the Oligocene and Lower Miocene than any other onshore outcrop or well provides.

The majority of published zonation schemes covering the study interval in NW Europe are based on onshore exposures or cores from onshore boreholes and focus on the stratigraphical lowest occurrences (LO) of dinoflagellates. Only a few North Sea wells have cored sections in the Oligocene or Lower Miocene interval; almost all well material is ditch cuttings samples, which are notoriously subject to downhole contamination. Therefore, dating these wells uses the first downhole occurrence (FDO) of taxa and the zonation schemes based on LO of taxa are of limited value. Major zonation schemes covering the Oligocene and Lower Miocene interval (partly or entirely) of the North Sea area (Costa \& Manum, 1988; Heilmann-Clausen \& Costa, 1989; Köthe, 1990; Gradstein et al., 1992; Powell, 1992; Gradstein \& Bäckström, 1996) are not as detailed as those covering the Paleocene and Eocene (e.g. Mudge $\&$ Bujak, 1996). Therefore, a second aim of the present work is to explore the possibilities for establishing a more detailed subdivision of the Oligocene and Lower Miocene based on FDOs of key dinoflagellates and acritarchs.

\section{MATERIAL AND METHODS}

During drilling of Alma-1X, cuttings samples were taken at every $30^{\prime}(9.1 \mathrm{~m})$ through the lower Neogene and Palaeogene. The present palynological study is based on 37 cuttings samples covering the interval 4550-6110' (1386.8-1862.3 m). The nearest uphole casing point is at $3855^{\prime}(1175.0 \mathrm{~m})$, preventing contamination from levels above that depth (i.e. Upper Miocene to Quaternary strata). All depths quoted here and in the systematic section are cuttings samples below rotary table and refer to the bottom depth of the sampling interval. 


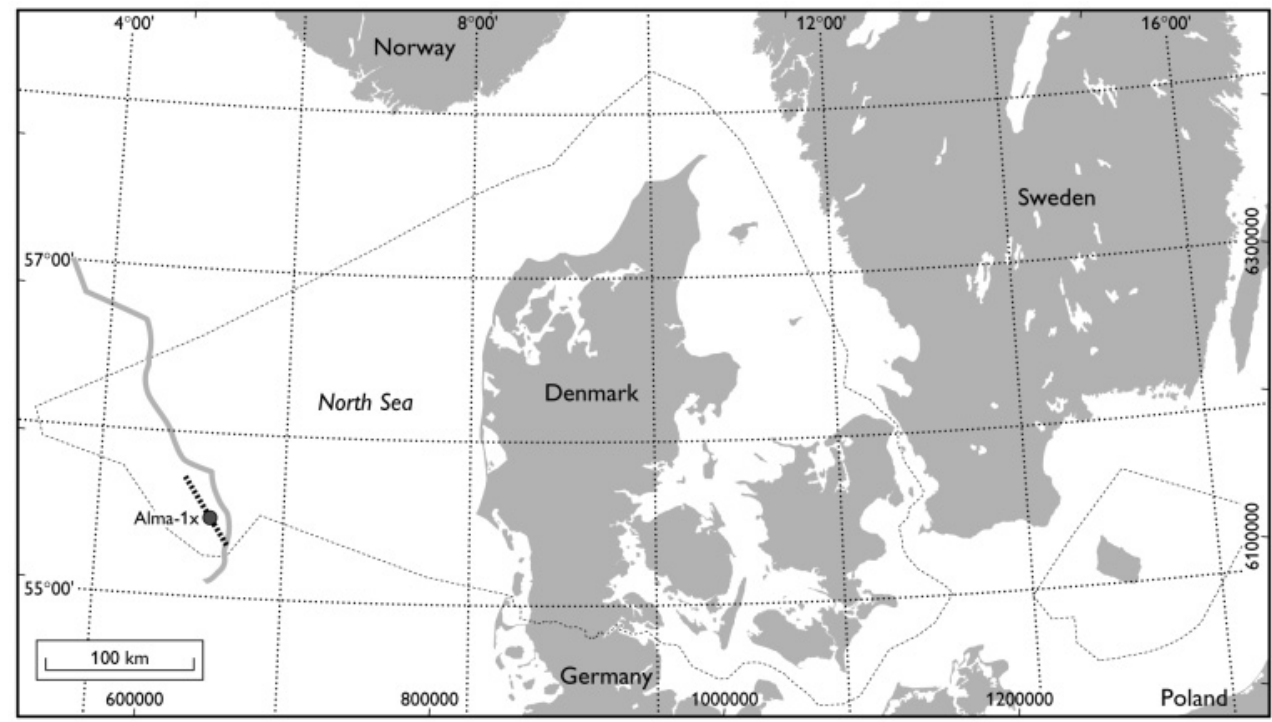

Fig. 1. Well location map. Dashed line indicates seismic line RTD81-RE94-17B (seismic section shown in Fig. 3). The Coffee Soil Fault, a major structural lineament in the Danish Sector that separates the East North Sea High from the Central Graben, is indicated for ease of orientation. Coordinates at the bottom and right-hand side of the figure are UTM; those of the top and left-hand side are geographical coordinates.

In the interval 6110-5450' (1862.3-1661.2 m) all the cuttings samples were studied, hence there is an uphole error of $30^{\prime}$ $(9.1 \mathrm{~m})$ for any event occurring in that interval. In the interval $5450-4550^{\prime}(1661.2-1386.8 \mathrm{~m})$ every second cuttings sample was studied, resulting in an uphole error interval of $60^{\prime}(18.3 \mathrm{~m})$.

The samples were processed following standard palynological preparation procedures (Batten, 1999); residues were sieved at $11 \mu \mathrm{m}$. A brief oxidation ( $2 \mathrm{~min}$ in $36 \%$ nitric acid) was carried out on all residues before they were separated using zinc cloride and mounted in glycerine jelly on microscope slides. Type mounts were sealed airtight with nail varnish.

The stratigraphical distributions of dinoflagellate and acritarch taxa encountered are shown in Figure 2. All taxa are listed alphabetically and referenced in a table available online at http://www.geolsoc.org.uk/SUP18218. A hard copy can be obtained from the Society library. The taxa are illustrated in Plates 1-19. LVR numbers refer to file numbers in the fossil image database of GEUS which contains all relevant curatorial details on each specimen. A SM number further identifies single specimen mounts. Types and paratypes are kept in the type collection of the Geological Museum of Copenhagen and have been given MGUH registration numbers in that collection. Figured specimens that are not type material are stored in the palynological slide collection of GEUS.

As Figure 2 indicates, reworked specimens occur throughout the well section, particularly in the upper Lark Formation. As a rule of thumb, isolated occurrences above a consistent occurrence interval in Figure 2 were interpreted as reworking unless the taxon in question is rare. In the latter case, isolated tops were accepted as in situ occurrences. However, isolated tops were not accepted for any of the key FDO events shown in Figure 2.

Dinoflagellate taxa mentioned in the text, figures and in the compiled taxa list (available online at http:// www.geolsoc.org.uk/SUP18218) and in Table 1 are cited and referenced in Williams et al. (1998) or herein. Suprageneric classification follows Fensome et al. (1993). Acritarch taxa are referenced in Fensome et al. (1990).

\section{LITHOSTRATIGRAPHY}

The lithostratigraphical subdivision of the Oligocene and Miocene follows that of Knox \& Holloway (1992). All samples studied, except the lowermost, belong to the Lark Formation. The lowermost sample is from the Horda Formation, identified on log signature and cuttings sample lithology (see below).

The studied section of Alma-1X is intersected by five surfaces that can be traced on seismic sections over large areas of the North Sea (Fig. 3). These surfaces can also be picked on the gamma log from the well (Fig. 4). Three of the surfaces mark the base of prograding wedge complexes and two are discontinuity surfaces.

The boundary between the Horda and Lark formations is sharp and unconformable and characterized by a change from dark, greenish-grey to greyish-green, fissile mudstones below the boundary to light-coloured, greenish-grey, in some wells dark brown, non-fissile mudstones above the boundary. On the gamma $\log$, this change is accompanied by an uphole increase to a consistently higher gamma response level in the Lark Formation at 6079.4' (1853.0 m) (Fig. 4). On the seismic section a conspicuous reflector (Top Horda, Fig. 3) marks the boundary.

Above the Top Horda reflector, a parallel seismic reflection pattern dominates the Lark Formation up to an Upper Oligocene unconformity (UOU Marker, Figs 3, 4). In the lower part of this interval the Lark 4 Marker is indicated by a prominent seismic reflector and a spike on the gamma log followed by an uphole decrease in gamma readings. Above the UOU Marker the general seismic architecture of the basin is characterized by large clinoforms separated by onlapping sediment wedges, and the lithology changes to brown to beigebrown mudstones. Two seismic reflectors, the Upper Lark 
North Sea Oligocene-Lower Miocene dinoflagellates and acritarchs

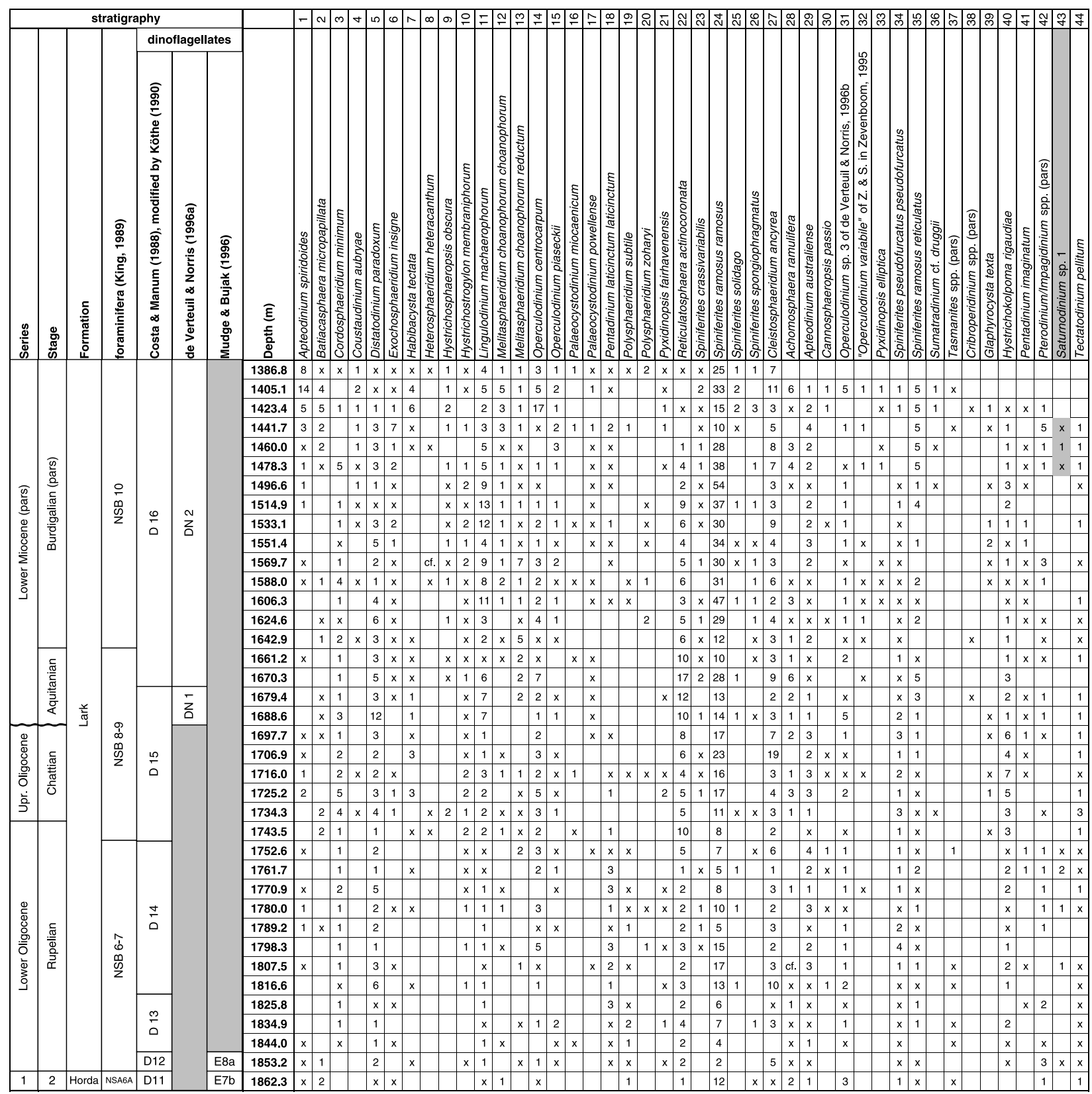

Fig. 2 .

Marker (ULM) and the Lark 18 Marker (Figs 3, 4), above the UOU Marker separate major prograding sediment packages. The Lark 18 Marker, located at the top of the studied interval, separates dominantly dark, beige-brown mudstones below from dark brown mudstones above.

\section{CHRONOSTRATIGRAPHY}

Following well completion a chronostratigraphical subdivision of the Palaeogene and Neogene section was established based on microfossils (unpublished data from Robertson Group plc.). Key microfossil events recorded in that study have been used herein for correlation with the agglutinating, benthic and planktonic microfossil microfossil zones (NSA, NSB and NSP) of King (1989) established for the North Sea (Fig. 4). King attempted to calibrate his zonal markers with the standard chronostratigraphic scale of Berggren et al. (1985a, b). However, only a few first-order correlations were possible; most of the calibrations were made using dinoflagellates, planktonic foraminifera and nannoplankton from onshore sections in the North Sea Basin (King, 1989); the correlation of the Lower Miocene is particularly uncertain (King, 1989, p. 446). Calcareous microfossils can be very rare or absent in thick intervals of the Palaeogene in the North Sea (including the interval studied herein).

In the absence of a good, self-contained microfossil biostratigraphy, the chronostratigraphical breakdown of Alma-1X relies heavily on a dinoflagellate biostratigraphy based on direct or indirect correlation with onshore type sections and/or 


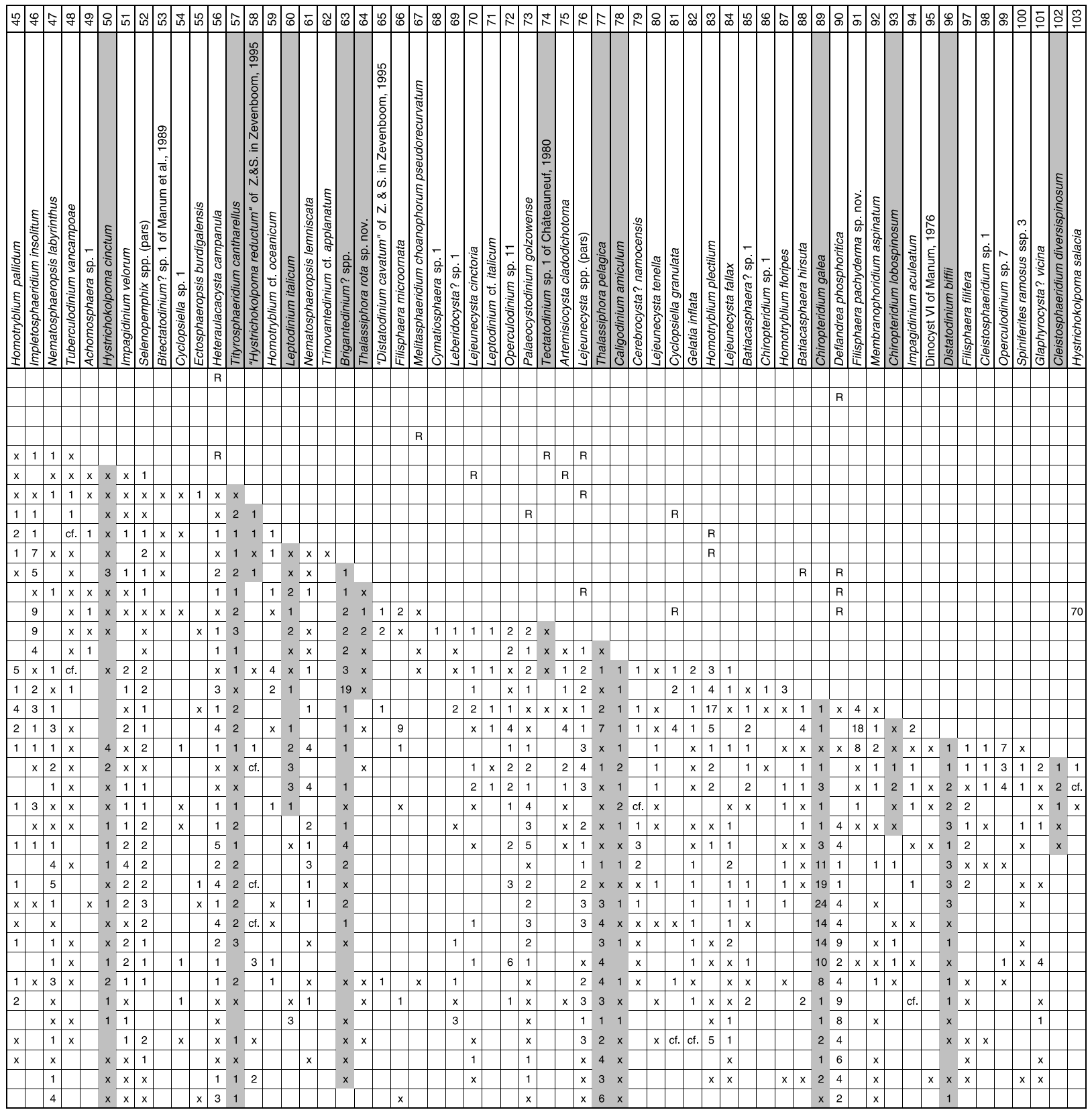

Fig. 2. Continued.

boundary type sections. Whenever possible, key microfossil datums have been used to support the biostratigraphy. The criteria used herein for stage and series divisions are listed below:

\section{Priabonian-Rupelian (Eocene-Oligocene) boundary}

At its Global Stratigraphical Section and Point (GSSP; Massignano section, central Italy), the Eocene-Oligocene boundary is bracketed by the highest occurrence (HO) of the dinoflagellates Cordosphaeridium funiculatum (above the boundary) and Heteraulacacysta porosa and Rhombodinium porosum (below the boundary) (Brinkhuis \& Biffi, 1993). The two latter events are located in the upper part of the Eocene Series (Brinkhuis \& Biffi, 1993; Vandenberghe et al., 2003). The $\mathrm{HO}$ of the dinoflagellate Areosphaeridium diktyoplokum is used commonly by North Sea biostratigraphers as evidence for penetration to the Eocene; however, this event occurs above the Eocene-Oligocene boundary in the GSSP type section, but at the top of the Priabonian Stage in the Priabonian type section (Brinkhuis, 1994; Brinkhuis \& Visscher, 1995) thereby creating a Priabonian-Rupelian boundary problem (see Brinkhuis \& Visscher, 1995). Other Eocene-Oligocene boundary sections in the type region were studied by Wilpshaar et al. (1996); however, additional key dinoflagellate events bracketing the boundary in these sections were either not encountered in the North Sea 
North Sea Oligocene-Lower Miocene dinoflagellates and acritarchs

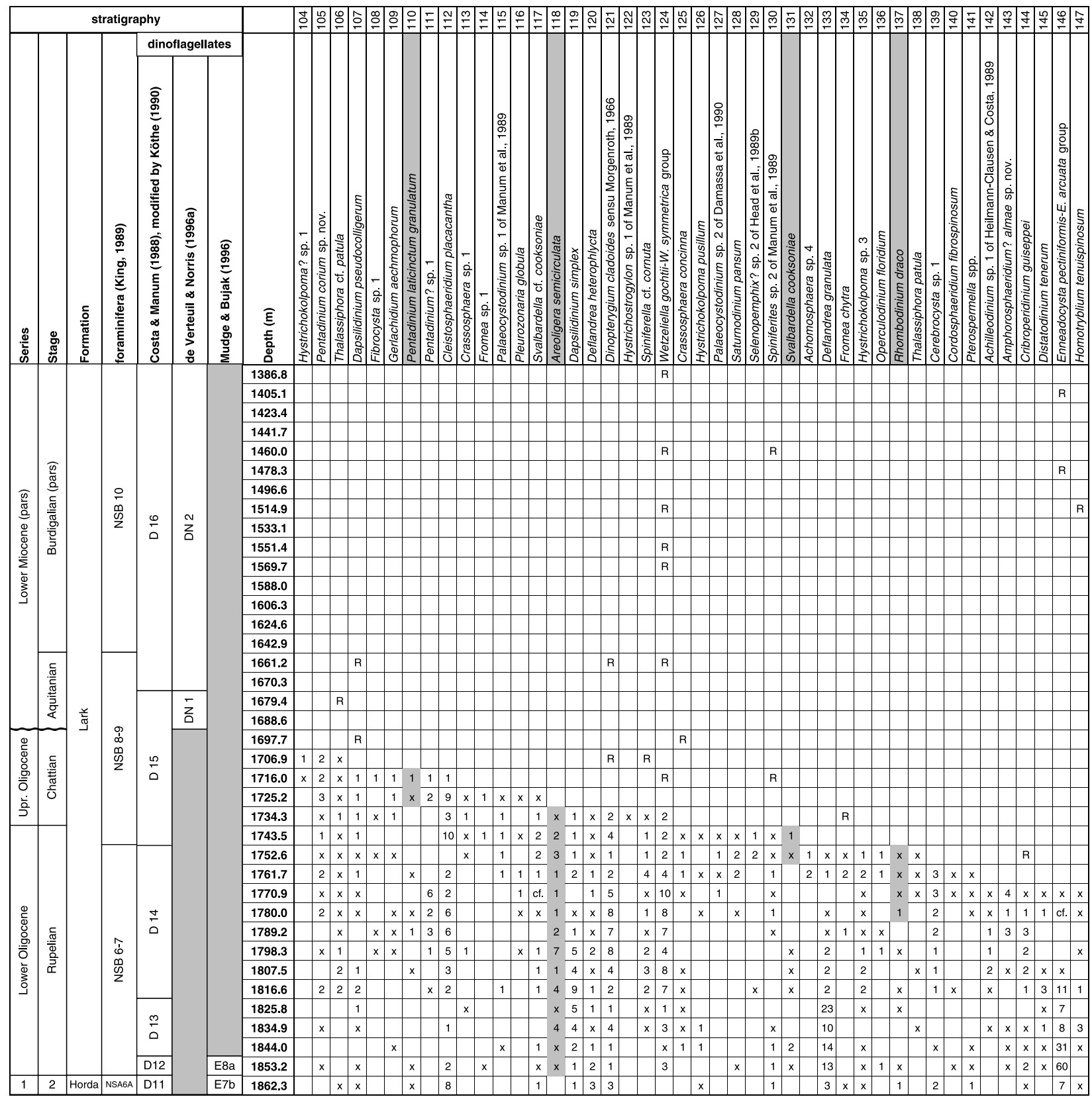

Fig. 2. Continued.

material studied herein, or represent first appearance datums which are of limited value here.

\section{Rupelian-Chattian (Lower-Upper Oligocene) boundary}

The principal criterion for this boundary has not, as yet, been decided by the Subcommission on Palaeogene Stratigraphy. Herein, the Rupelian-Chattian stage boundary is placed at the $\mathrm{HO}$ of the benthic foraminifera Rotaliatina bulimoides, a conspicuous event used by most North Sea biostratigraphers as the boundary marker. The HO of $R$. bulimoides marks the top of the NSB7 Zone of King (1983) and the NSR7 Zone of Gradstein et al. (1994). The HO of $R$. bulimoides is at $29 \mathrm{Ma}$ in the North
Sea according to Gradstein \& Bäckström (1996); slightly older than the 28.5 Ma age for the Rupelian-Chattian Stage boundary quoted by Hardenbol et al. (1998). In many North Sea wells studied by the present author, including Alma-1X, the FDO of $R$. bulimoides coincides approximately with the FDO of the dinoflagellate Rhombodinium draco.

\section{Chattian-Aquitanian (Oligocene-Miocene) boundary}

This boundary is bracketed by a number of HOs at its type section (Lemme-Carosio, northwest Italy). Unfortunately, none of the foraminifera events are believed to be true stratigraphical tops (facies limited), and reworking in the section hampers use 


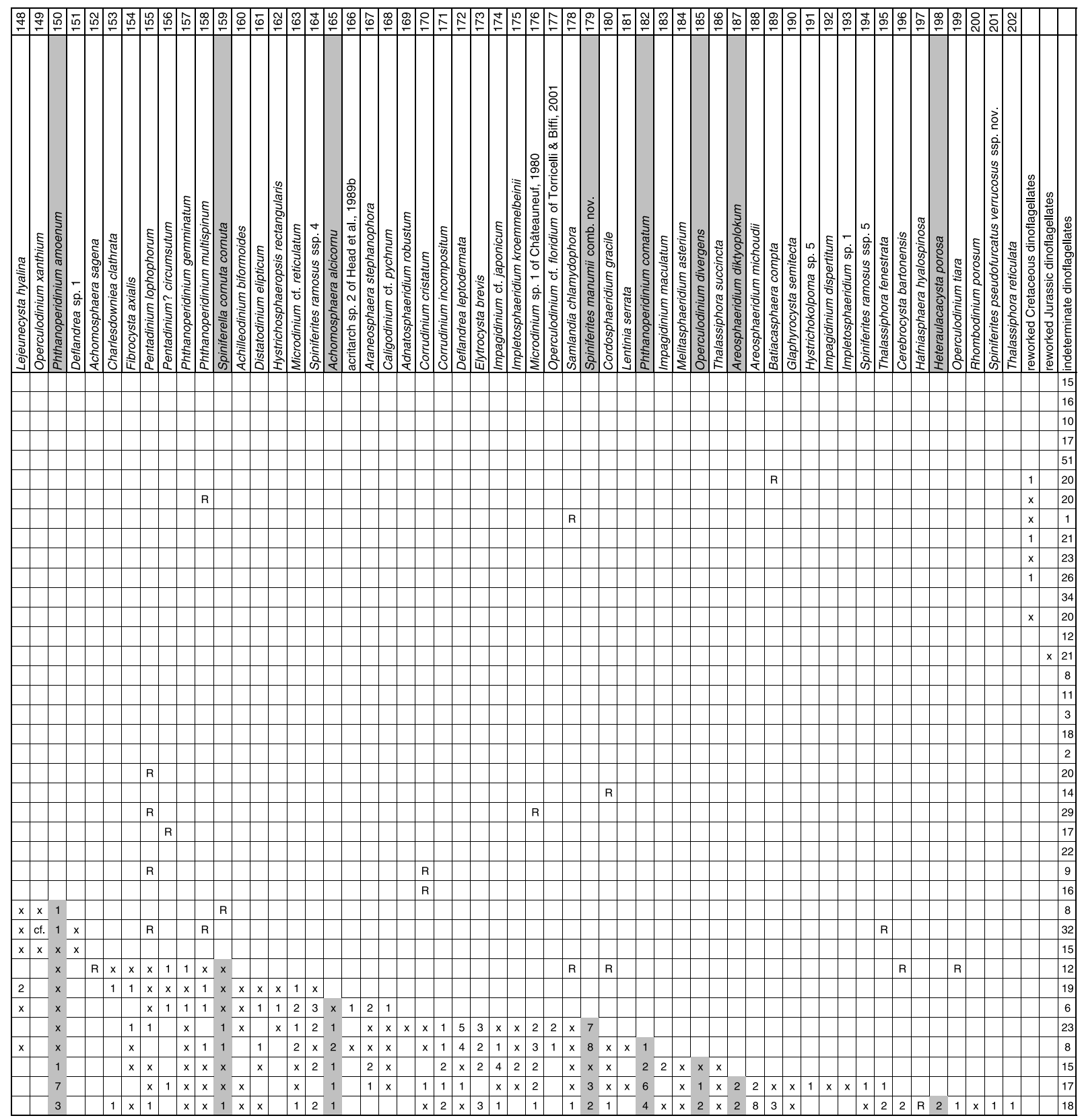

Fig. 2. Continued.

Fig. 2. Taxon distribution chart. The persistent occurrence intervals of key taxa (listed in Table 1, underlined in Fig. 4) are shaded. 1 in the Series column refers to Eocene; 2 in the Stage column refers to Bartonian; R is assumed reworked; $x$ is occurrence outside count. Sources: foraminifera, King (1989); dinoflagellates, Costa \& Manum (1988), modified by Köthe (1990); de Verteuil \& Norris (1996a); Mudge \& Bujak (1996).

of nannofossil tops (Steininger et al., 1997). However, the dinoflagellate succession from the Lemme-Carosio section has been documented in detail by Powell (1986a), Brinkhuis et al. (1992) and Zevenboom $(1995,1996)$ and provides means for direct correlation between it and the North Sea Basin. The HO of Distatodinium biffii is below the Chattian-Aquitanian boundary in its type section and the $\mathrm{HO}$ of Chiropteridium spp. is above. This event succession can be recognized in many North Sea wells and the Chattian-Aquitanian boundary is positioned between the two. When positioned in this way, the Chattian-Aquitanian boundary is closely below the FDO of small forms of the diatom Aulacodiscus insignis quadrata, a widespread event in the North Sea.

\section{Aquitanian-Burdigalian boundary}

The principal criteria for the Aquitanian-Burdigalian boundary are undecided and the correlation is based on the dinoflagellate zonation scheme of de Verteuil \& Norris (1996a), established 

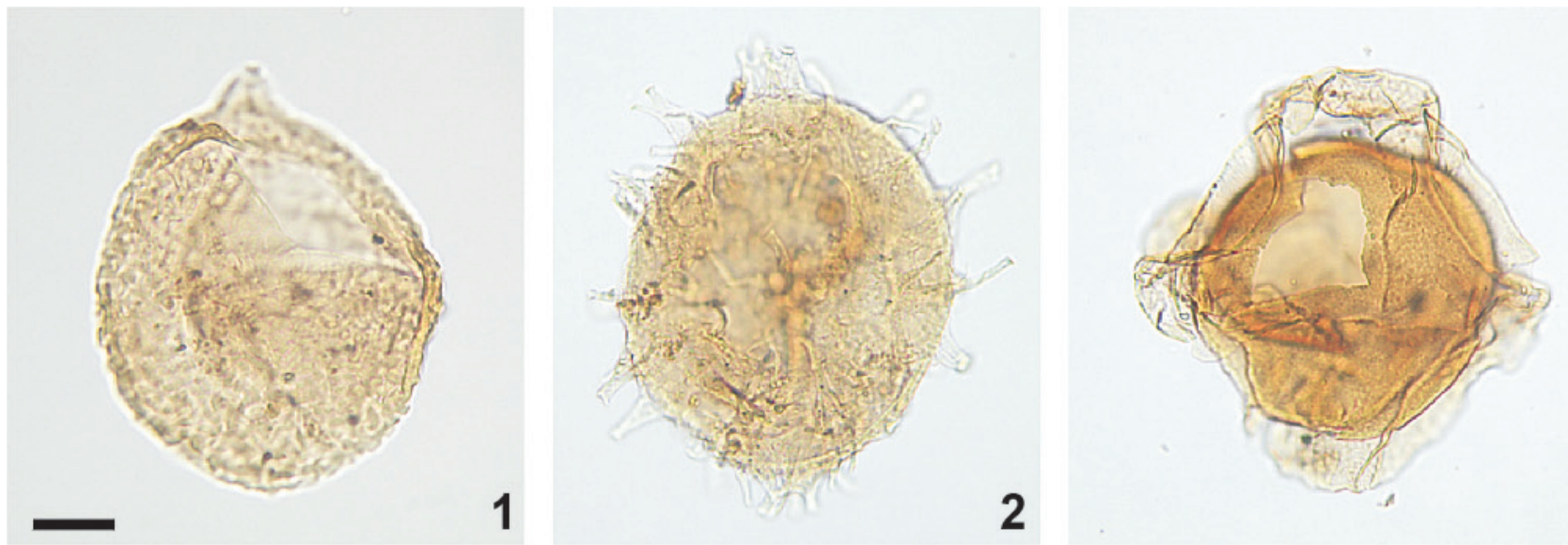

3
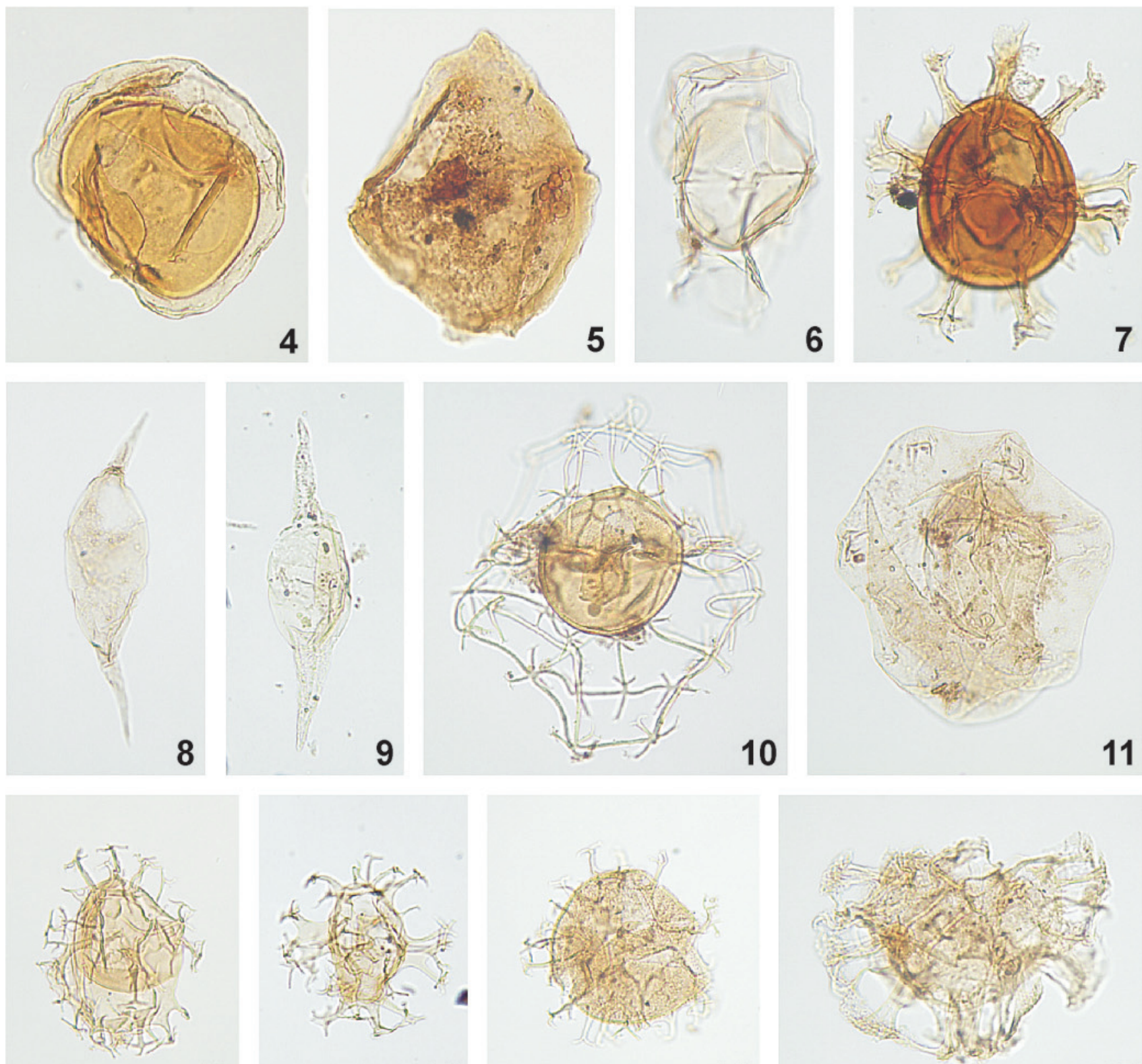

12

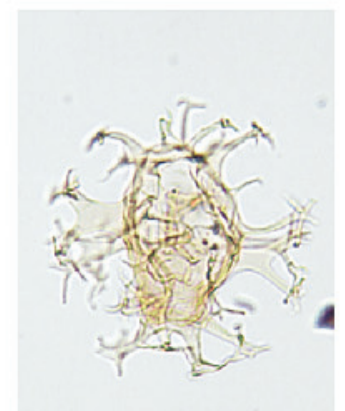

13

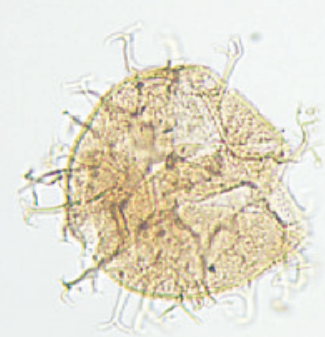

14

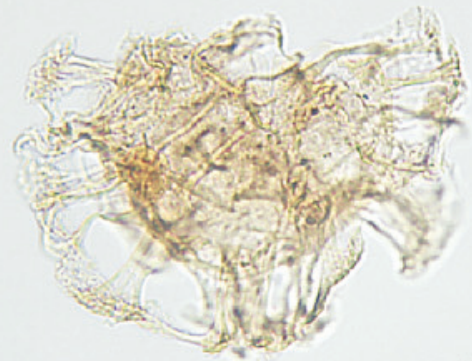

15

Plate 1. For full plate explanation see page 32. 

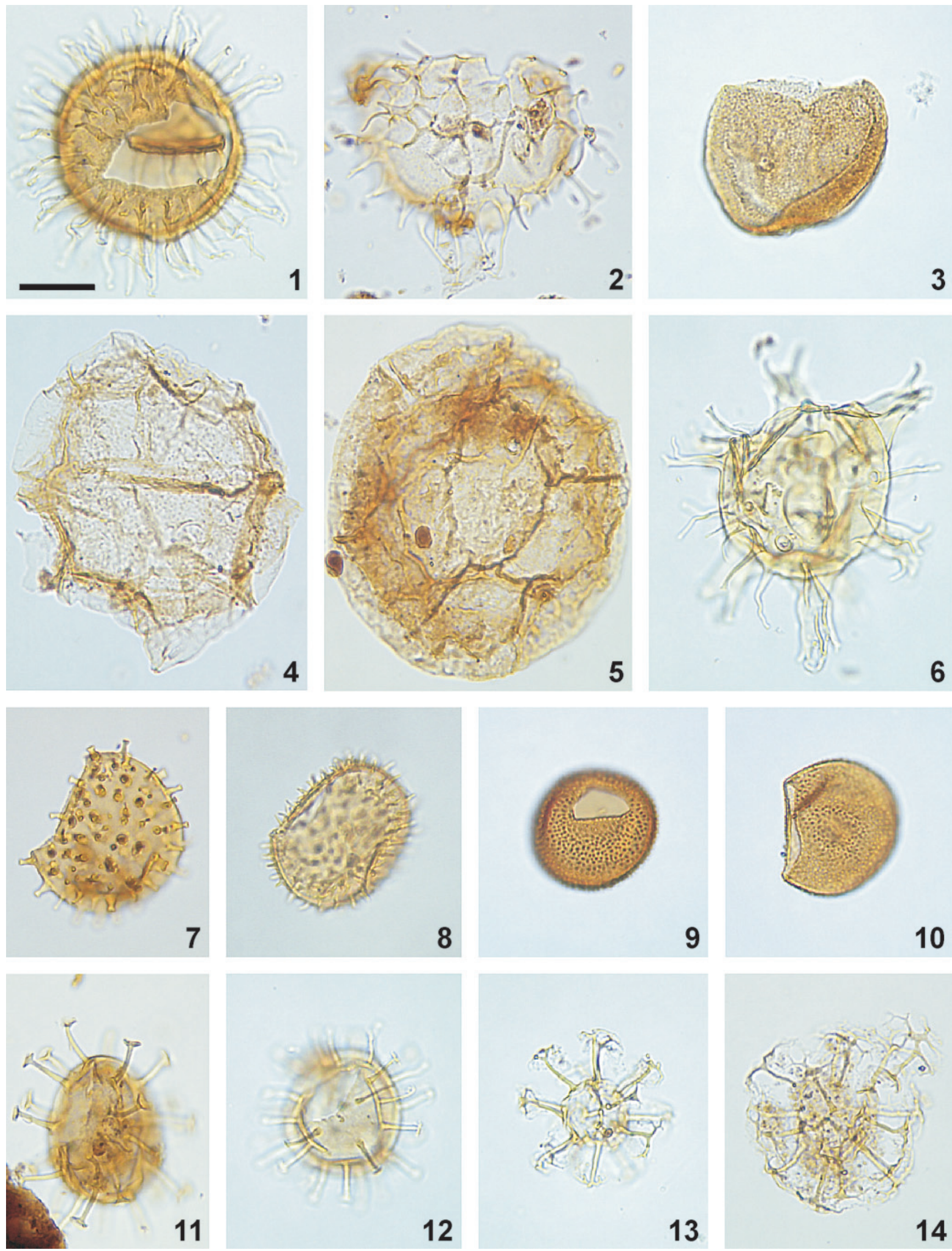

12
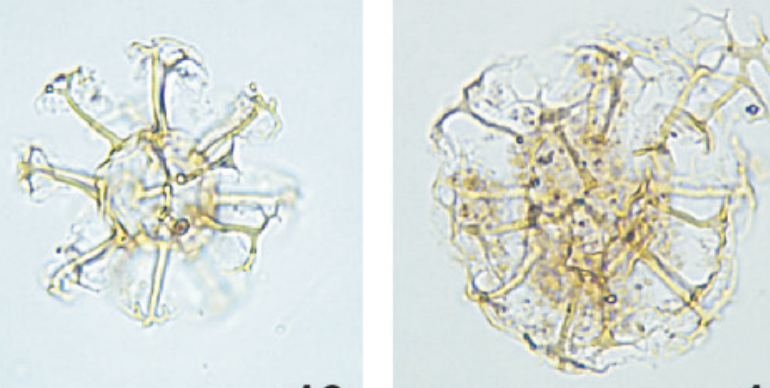

13

14

Plate 2. For full plate explanation see page 33. 


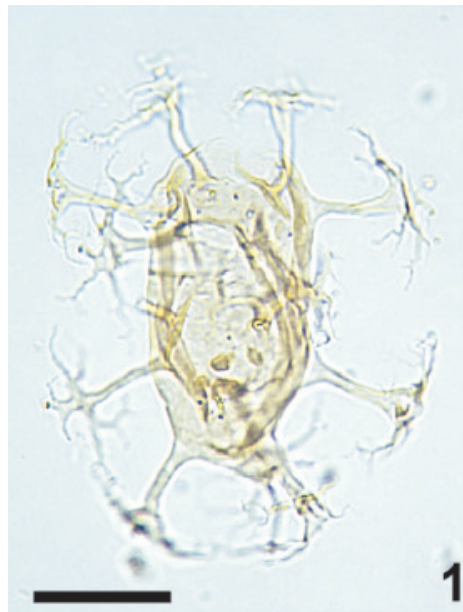

1
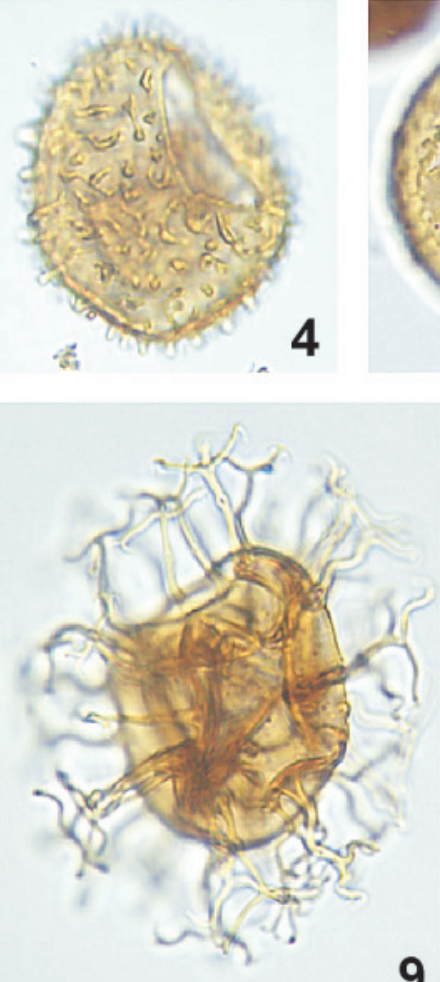

9

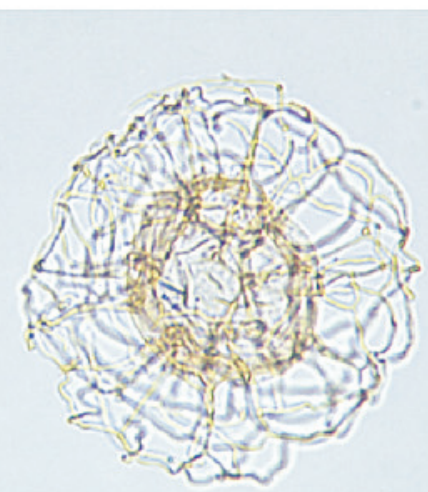

12
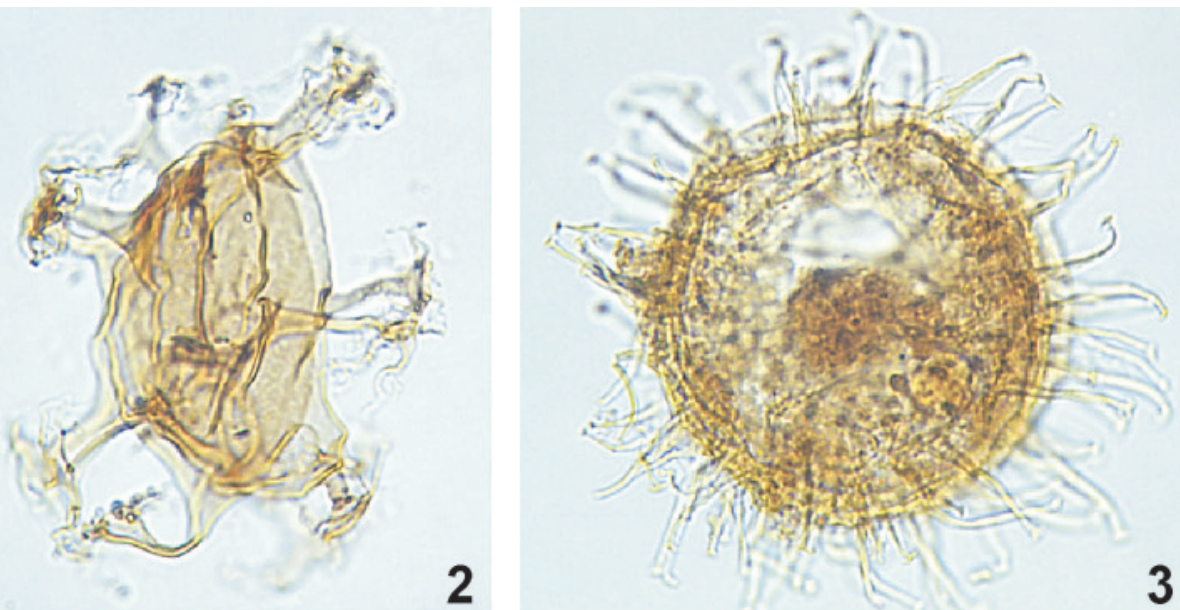

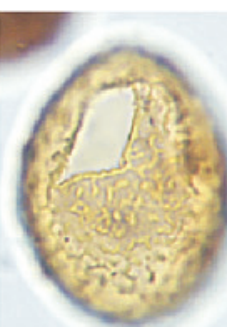

5

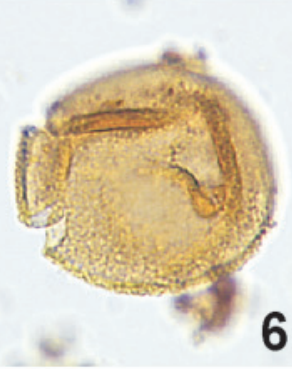

6
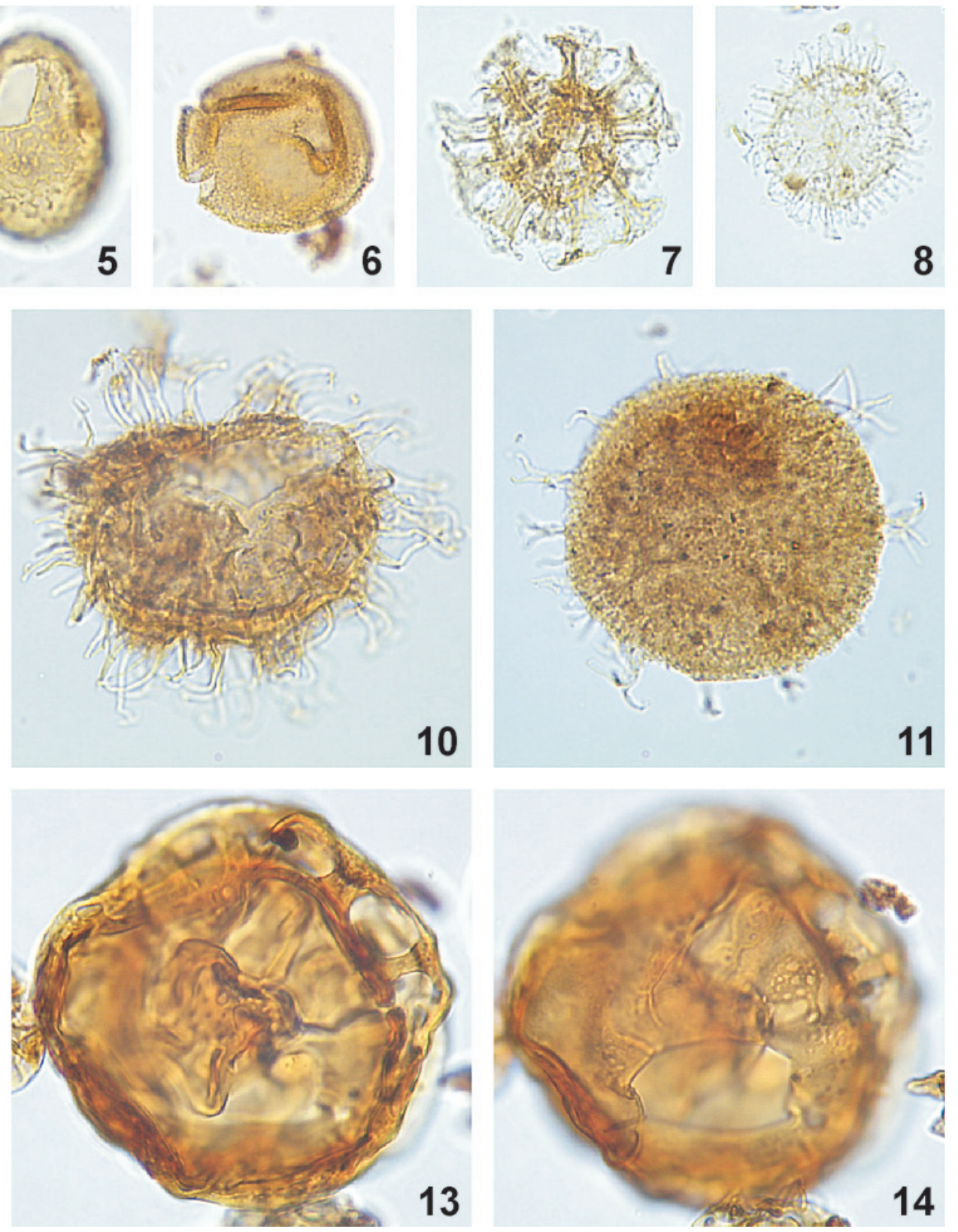

Plate 3. For full plate explanation see page 33. 

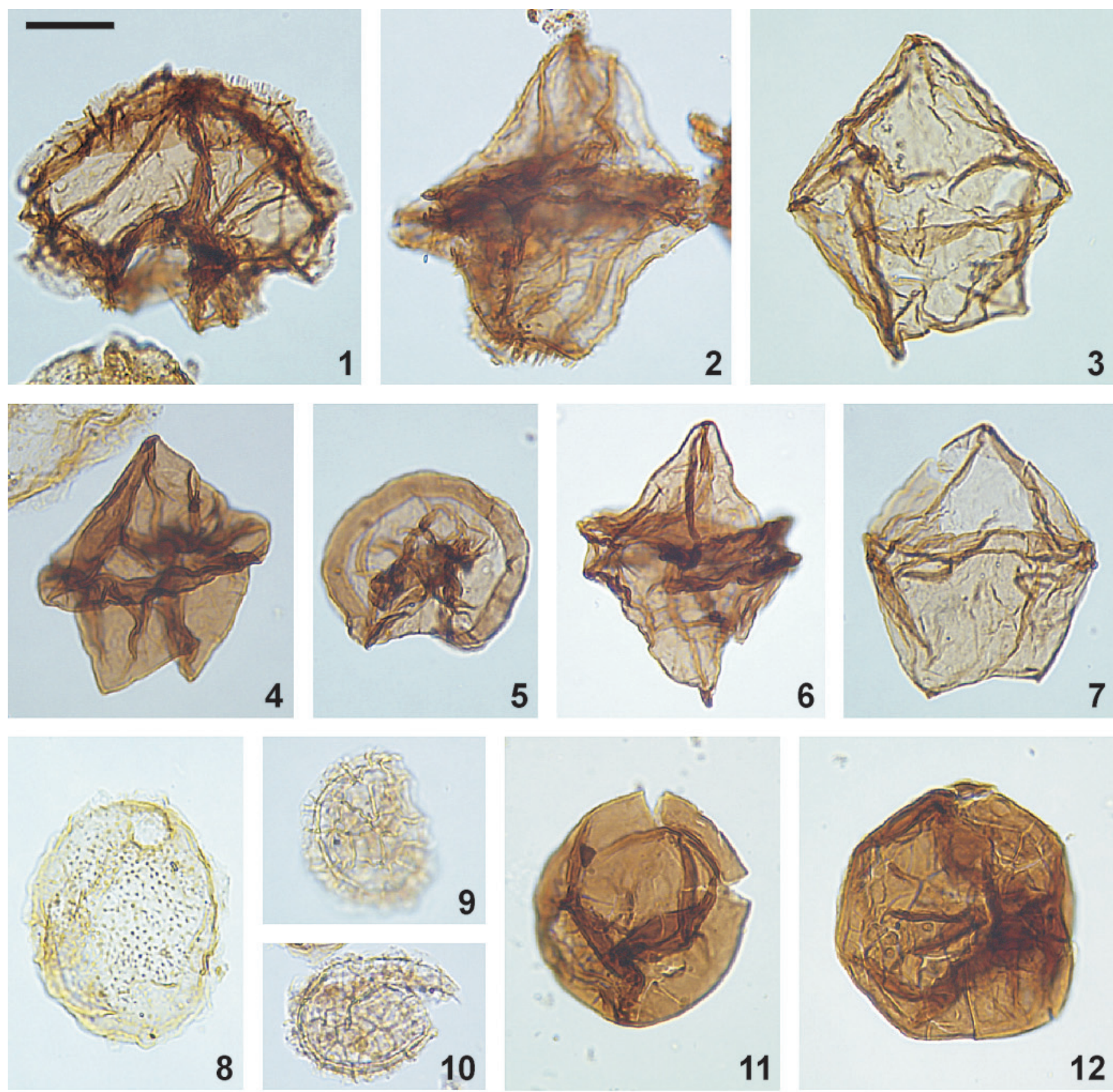

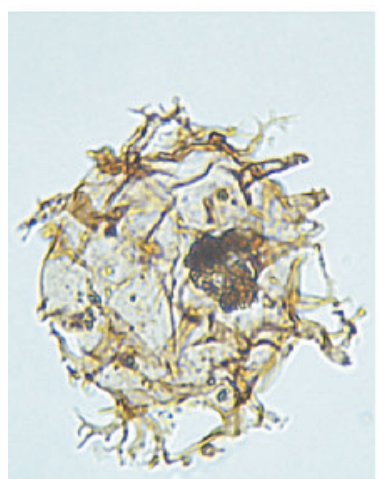

13

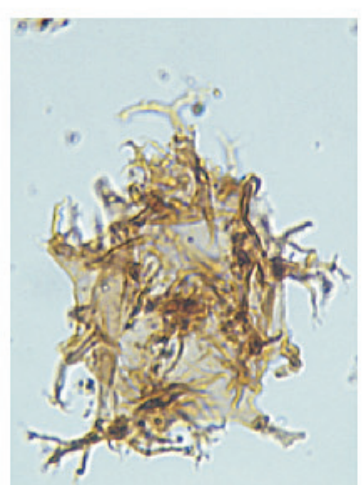

14

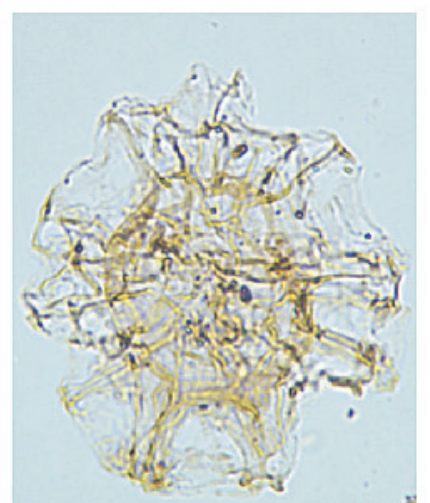

15

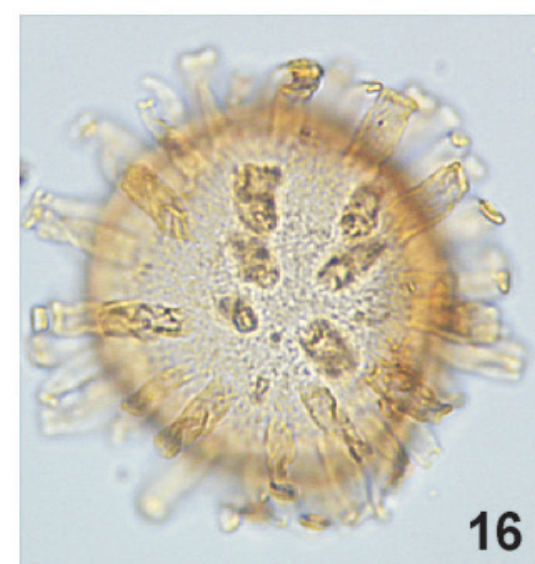

Plate 4. For full plate explanation see page 33. 

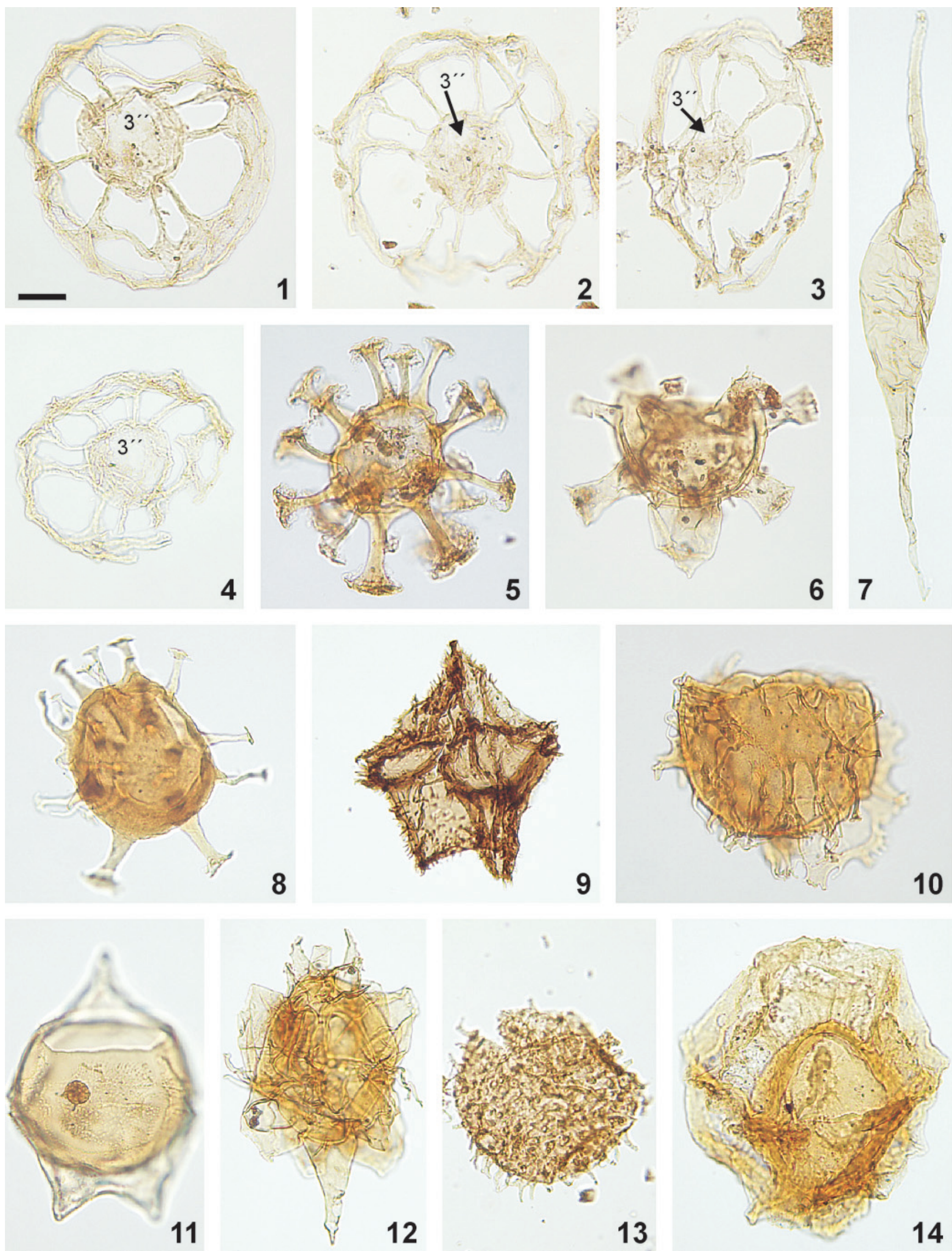

Plate 5. For full plate explanation see page 33. 

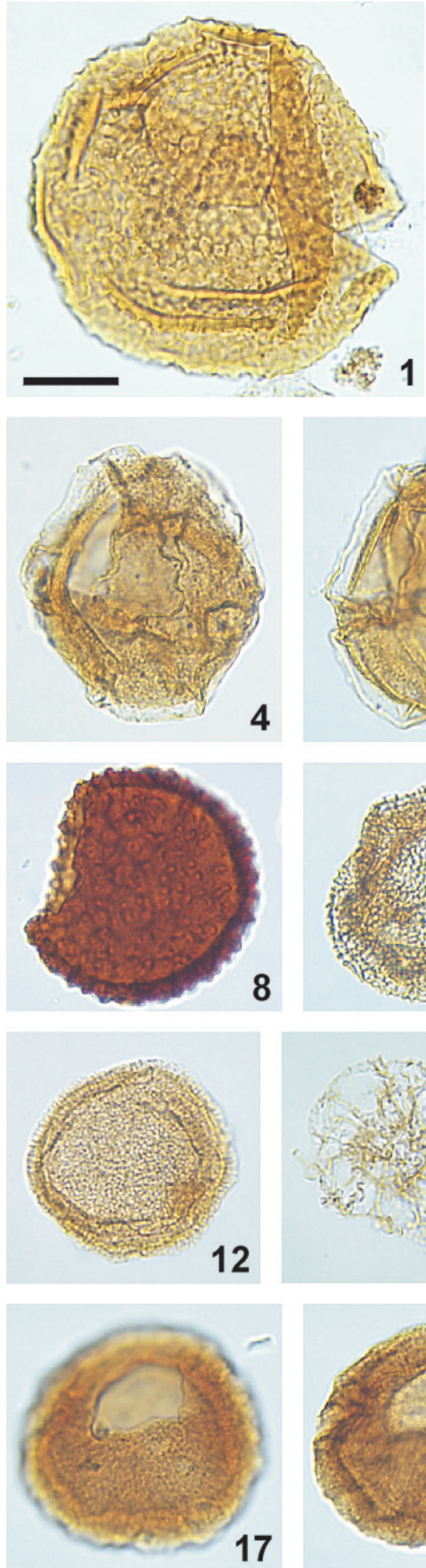
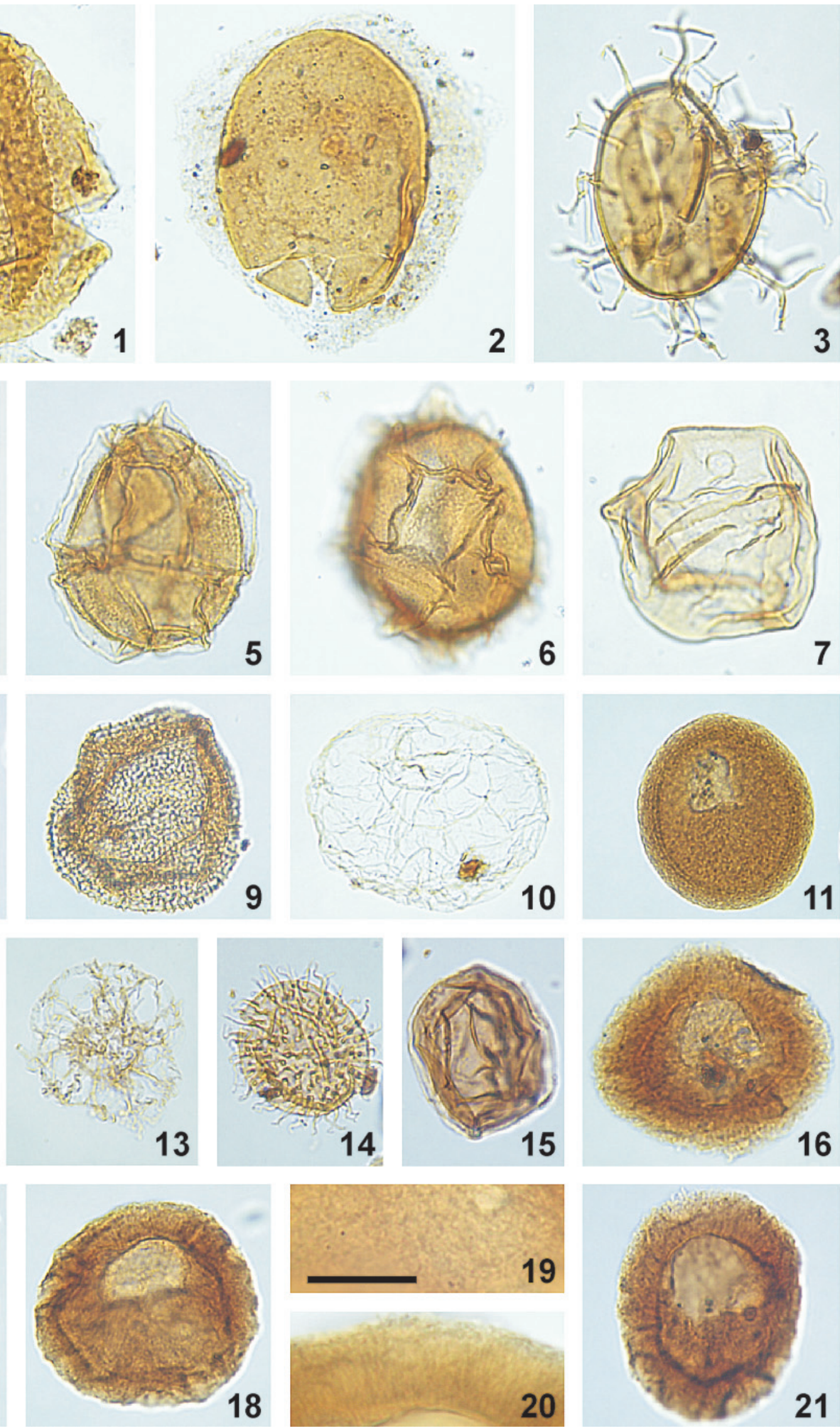

Plate 6. For full plate explanation see page 33. 

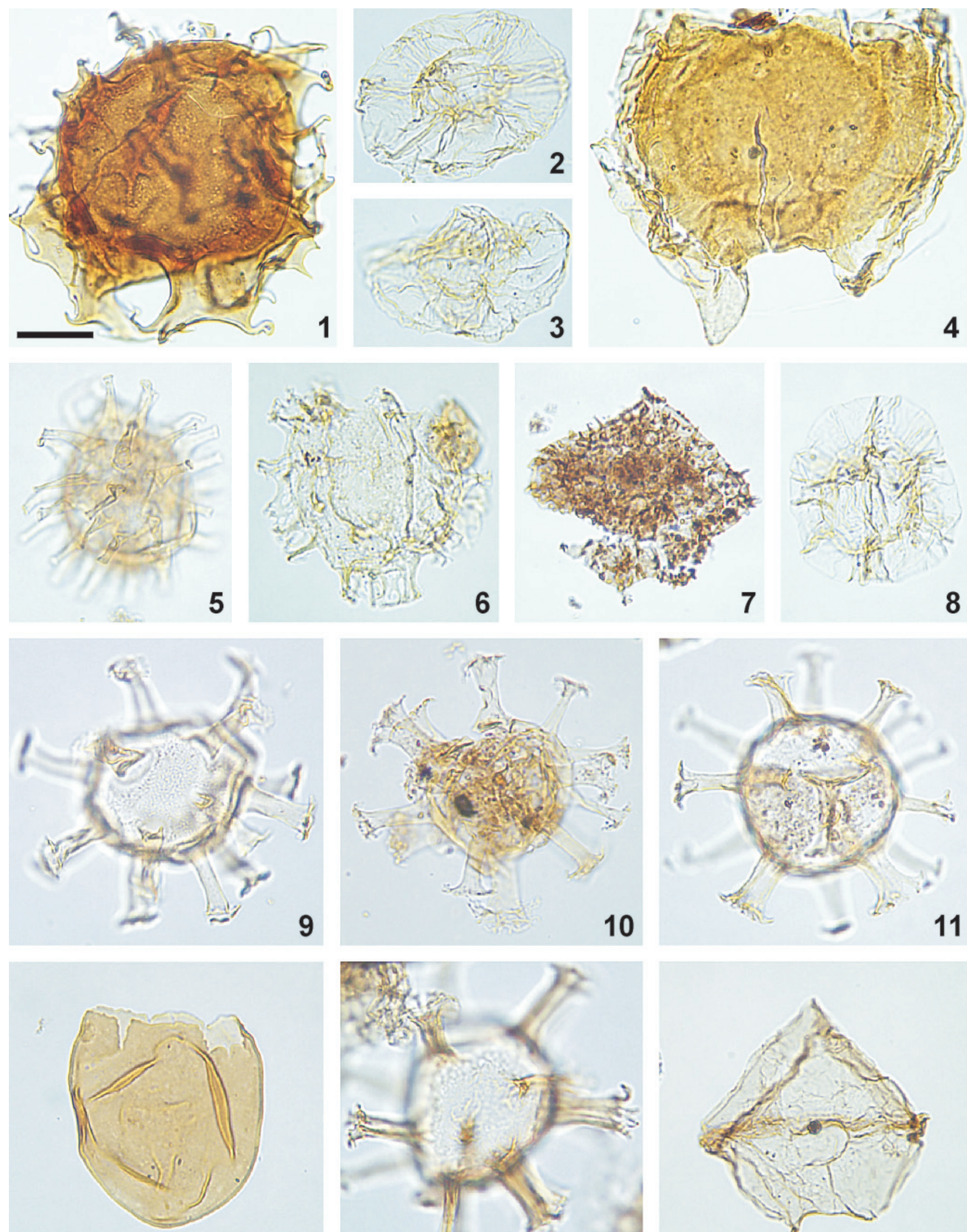

12
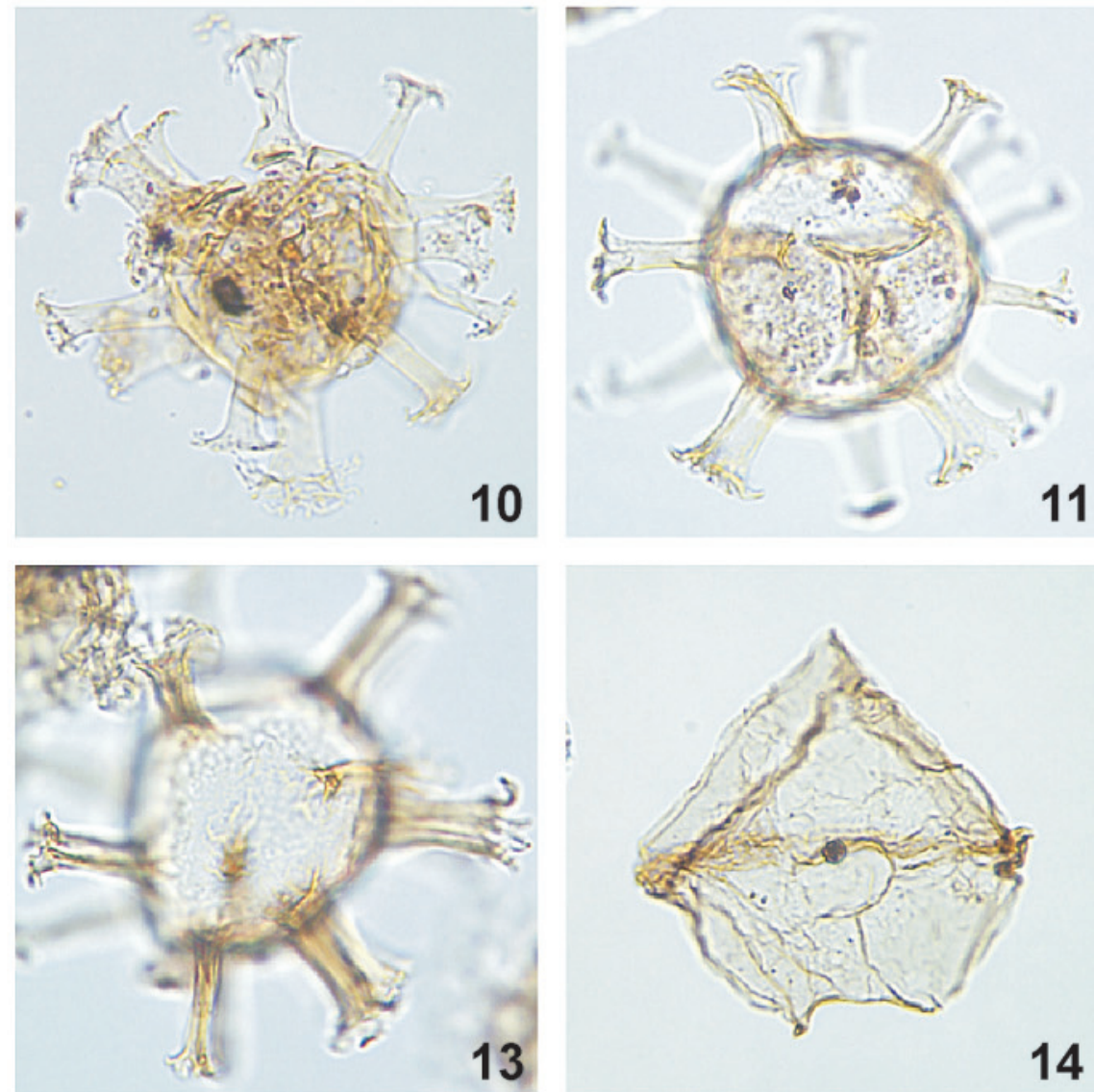

Plate 7. For full plate explanation see page 34.

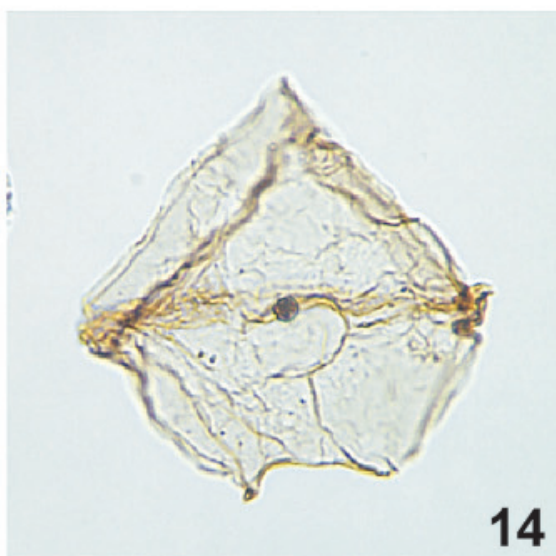

14 

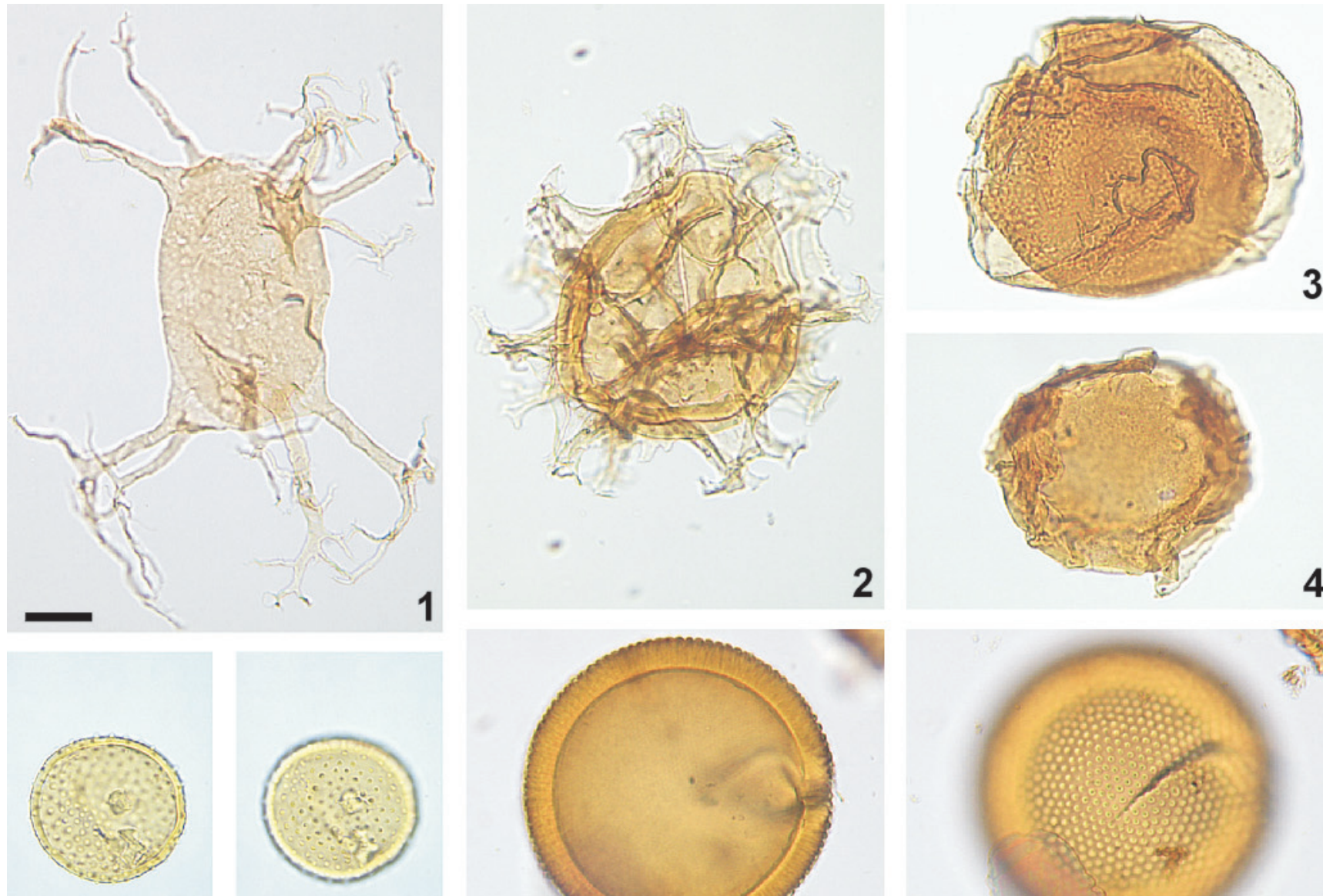

5

6
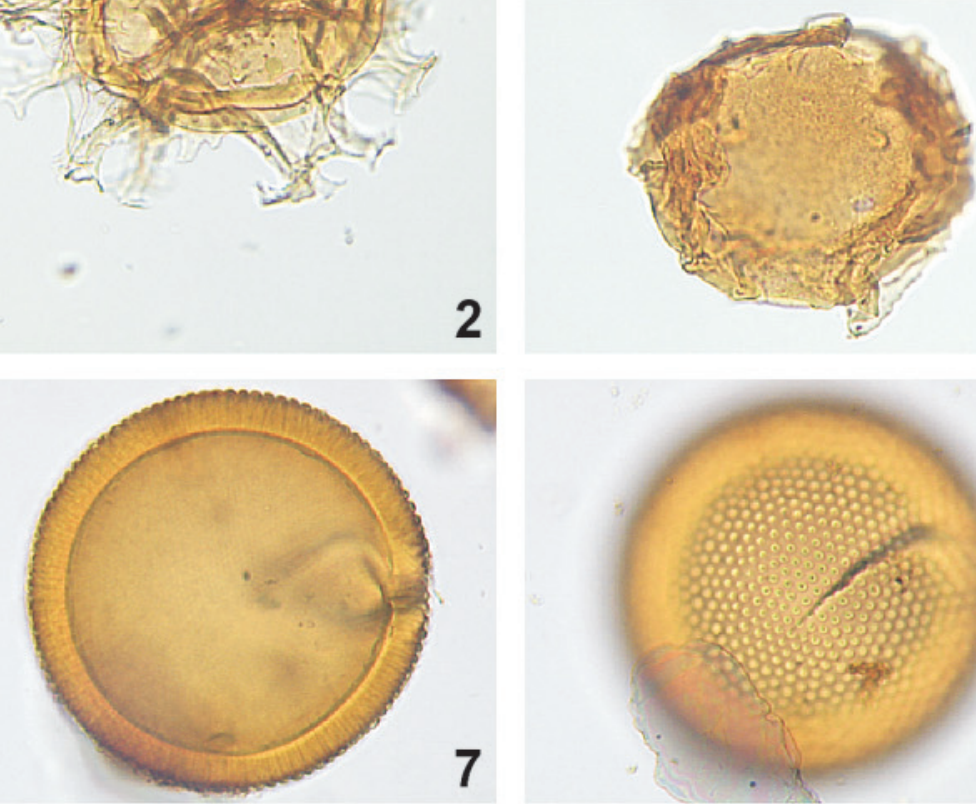

4

कर्ष

8
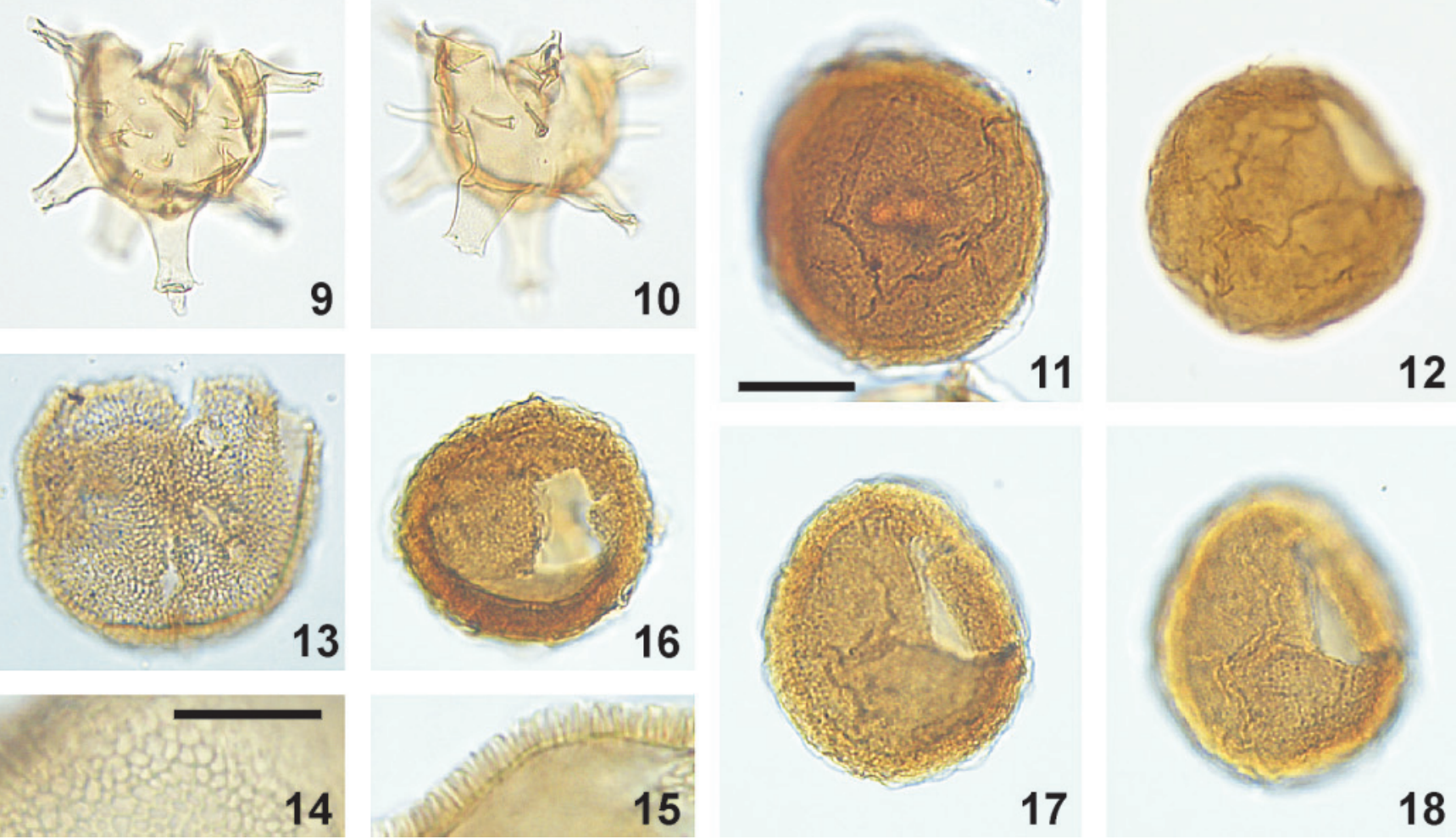

17

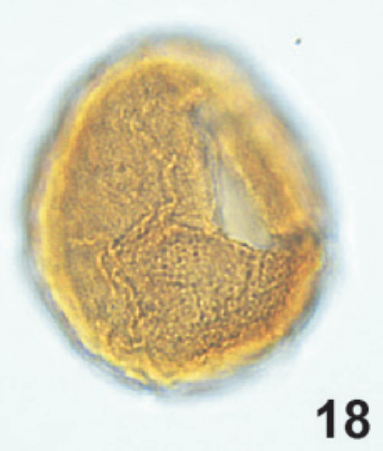

Plate 8. For full plate explanation see page 34. 

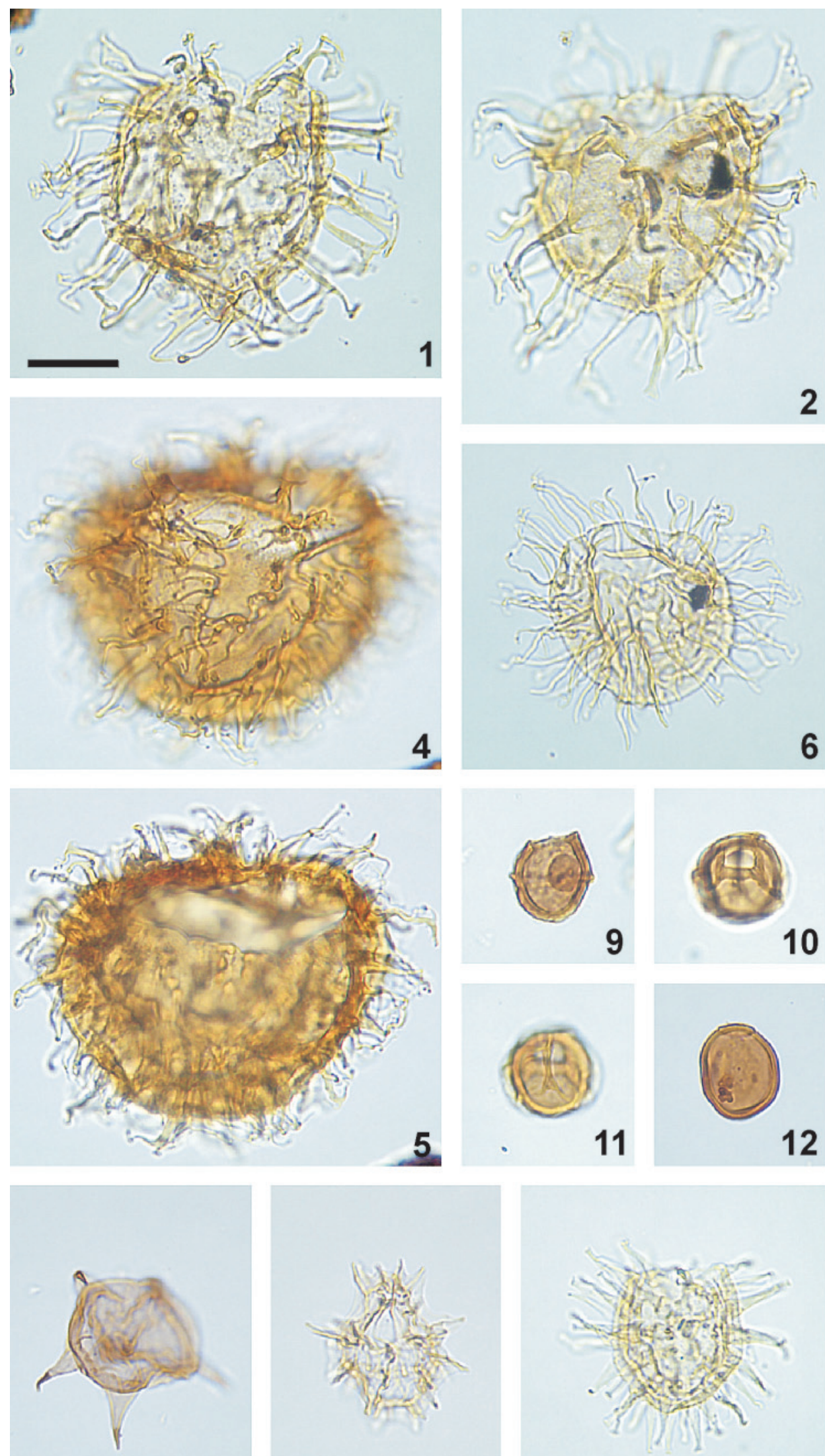

14

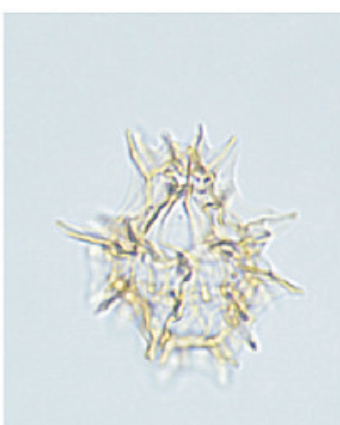

15

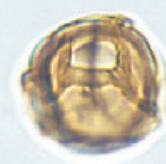

10

12
6

9
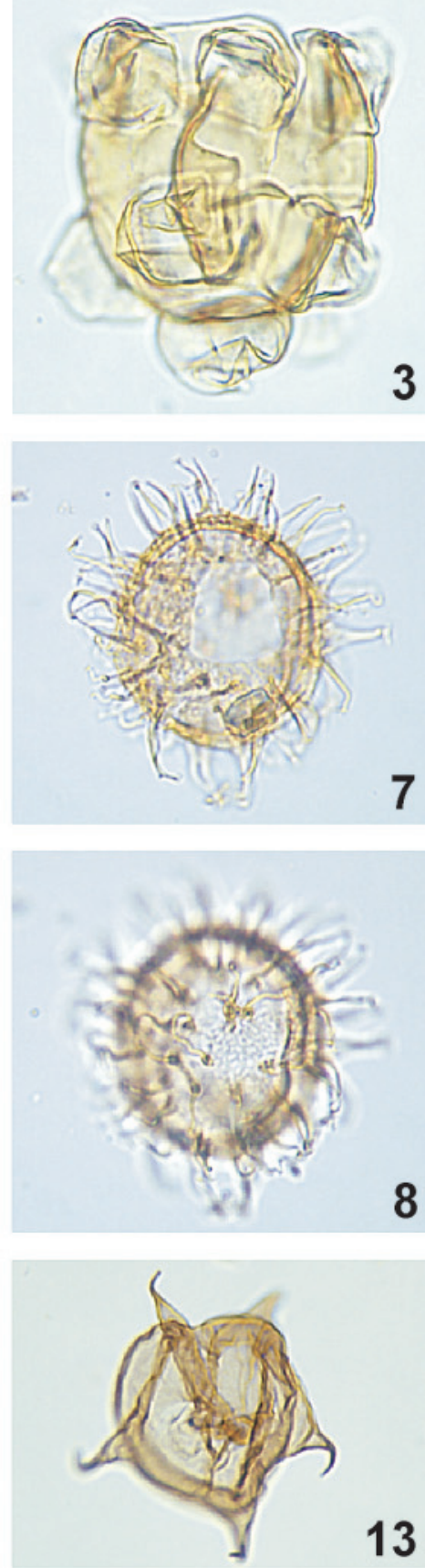

13

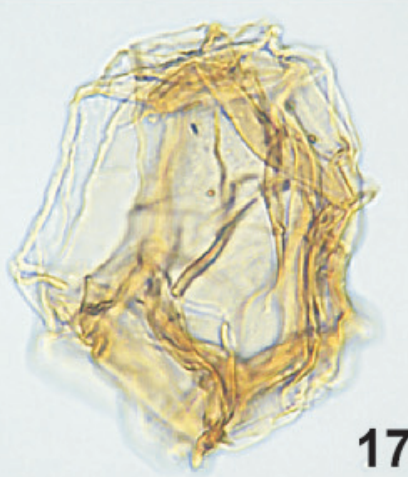

Plate 9. For full plate explanation see page 34. 


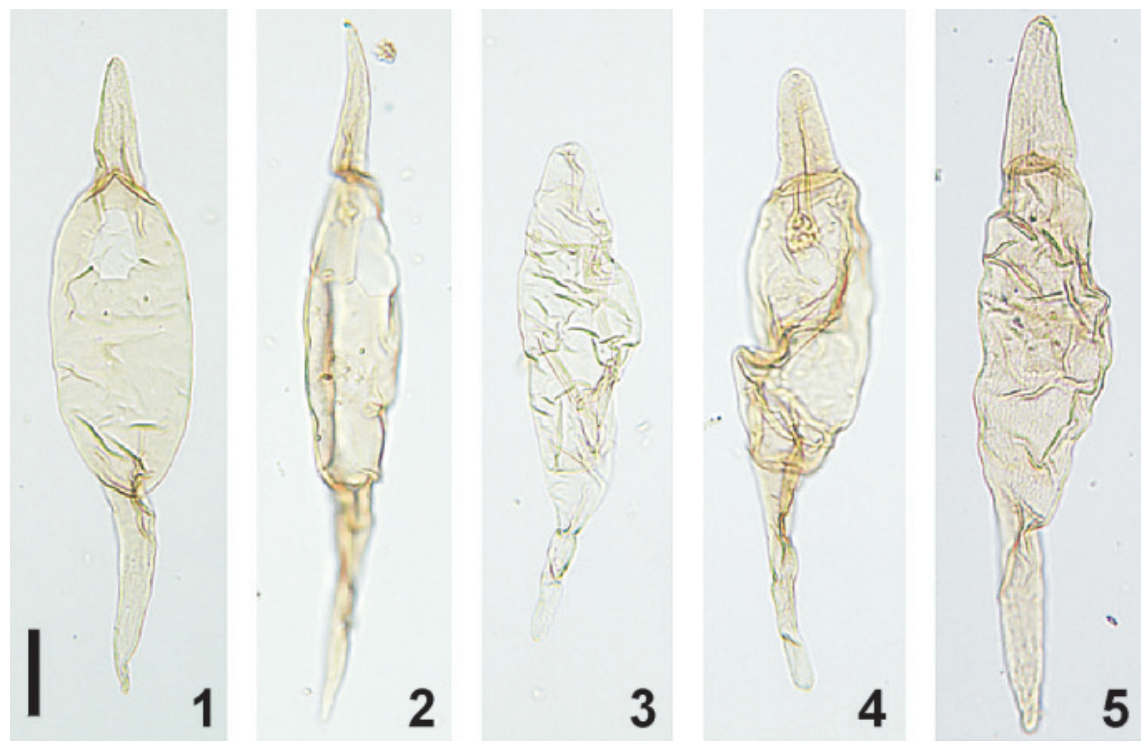

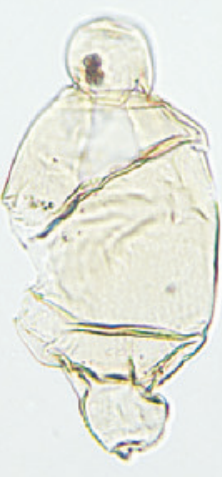

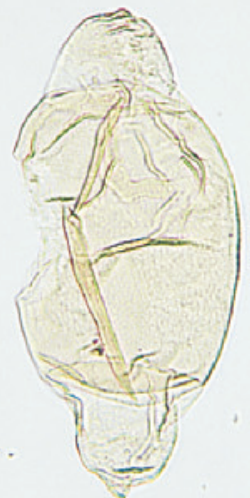

6

7
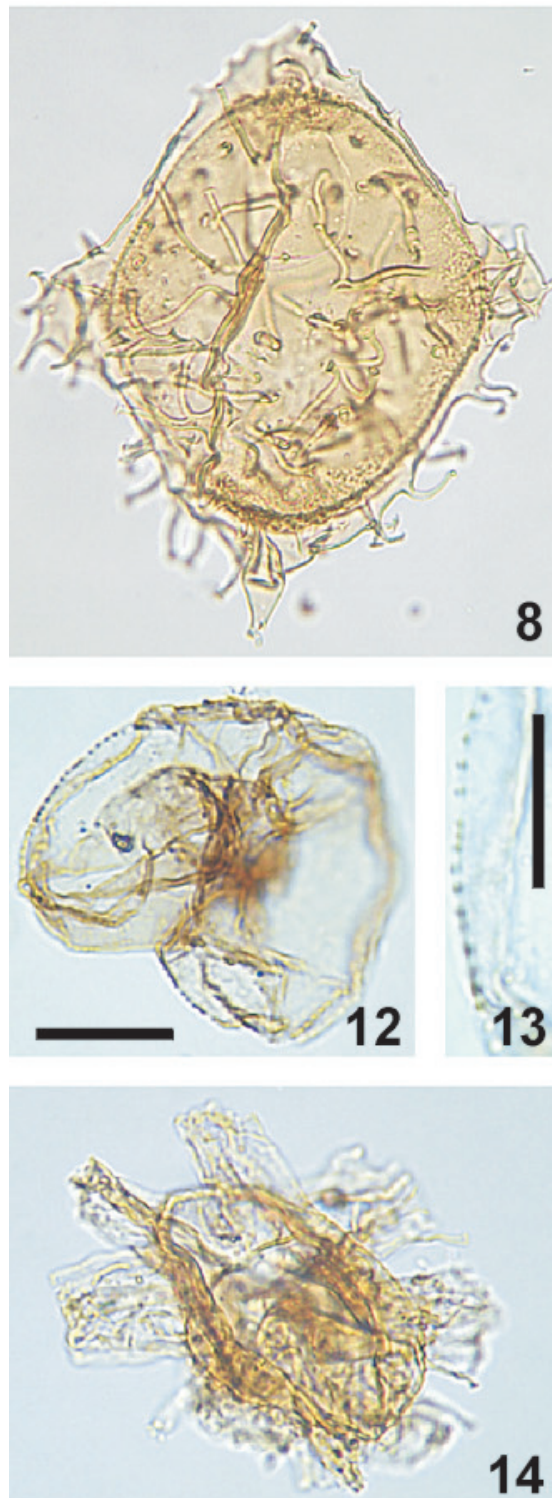
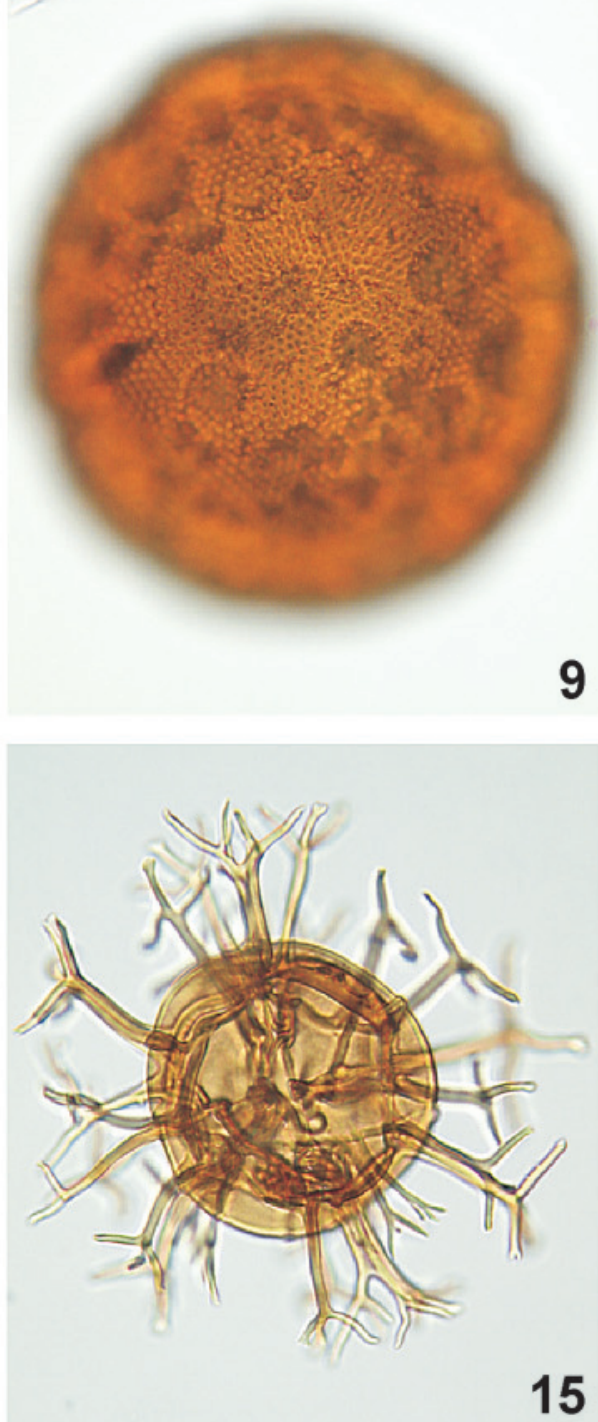

15

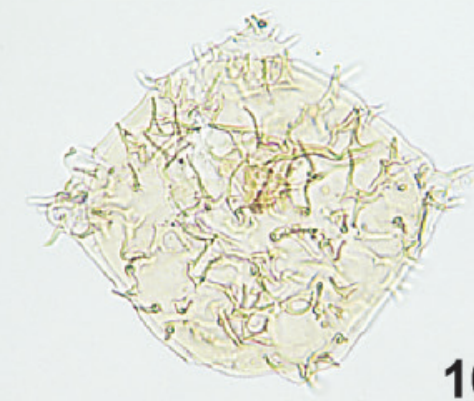

10

11

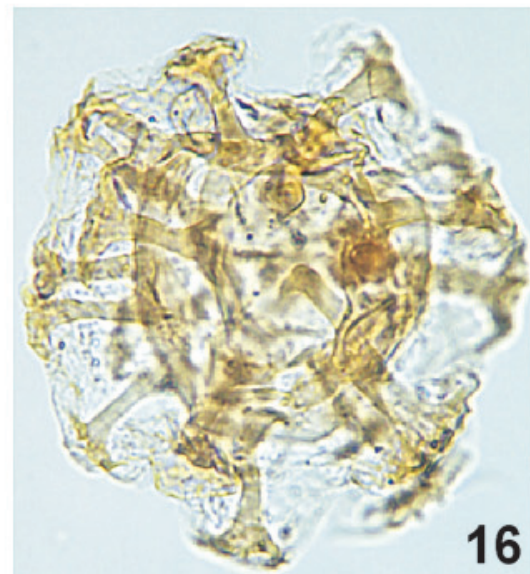

Plate 10. For full plate explanation see page 34. 

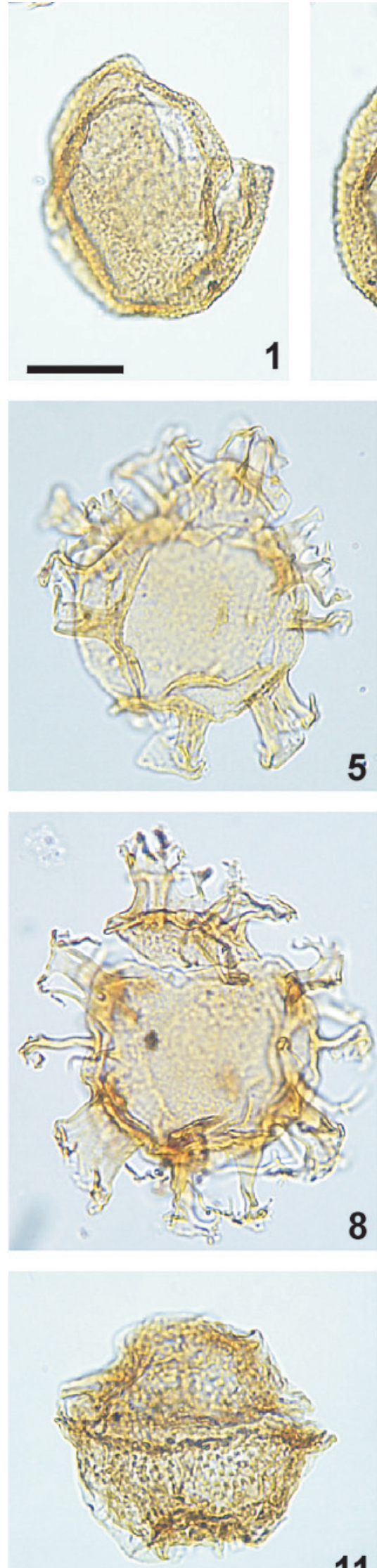

11
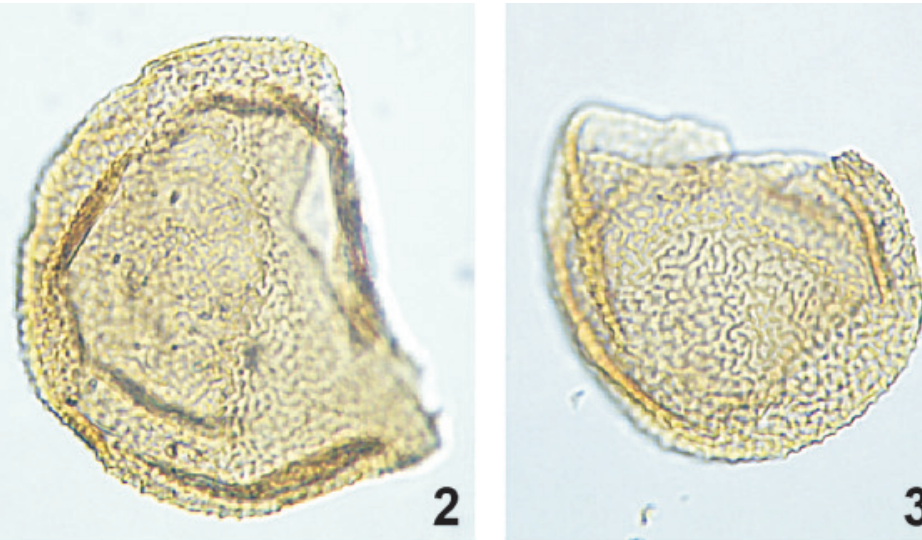

3
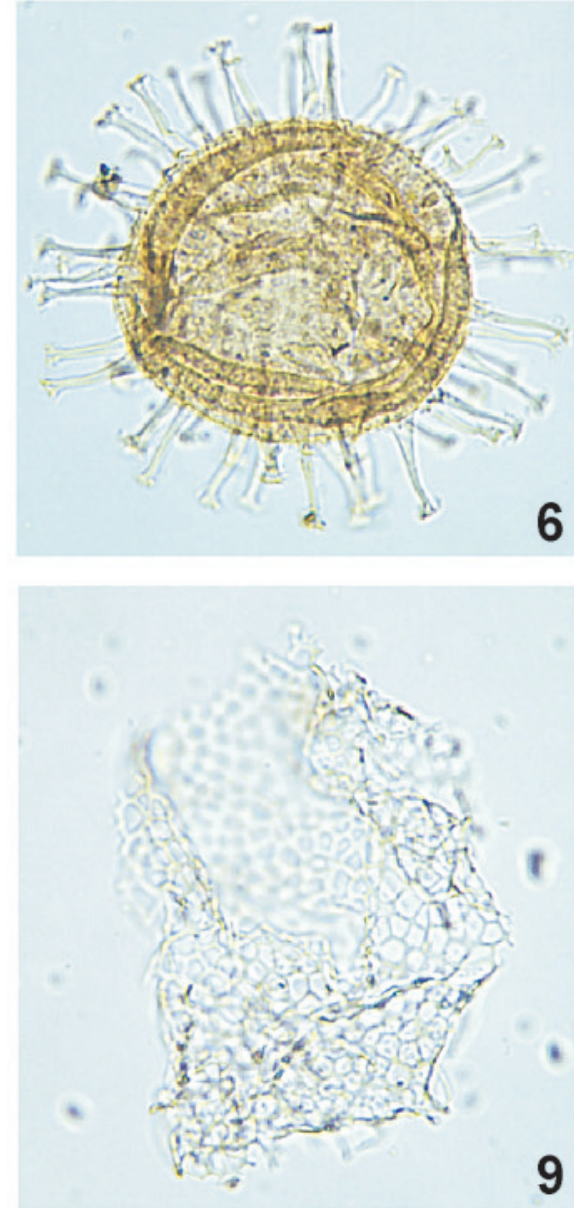

9

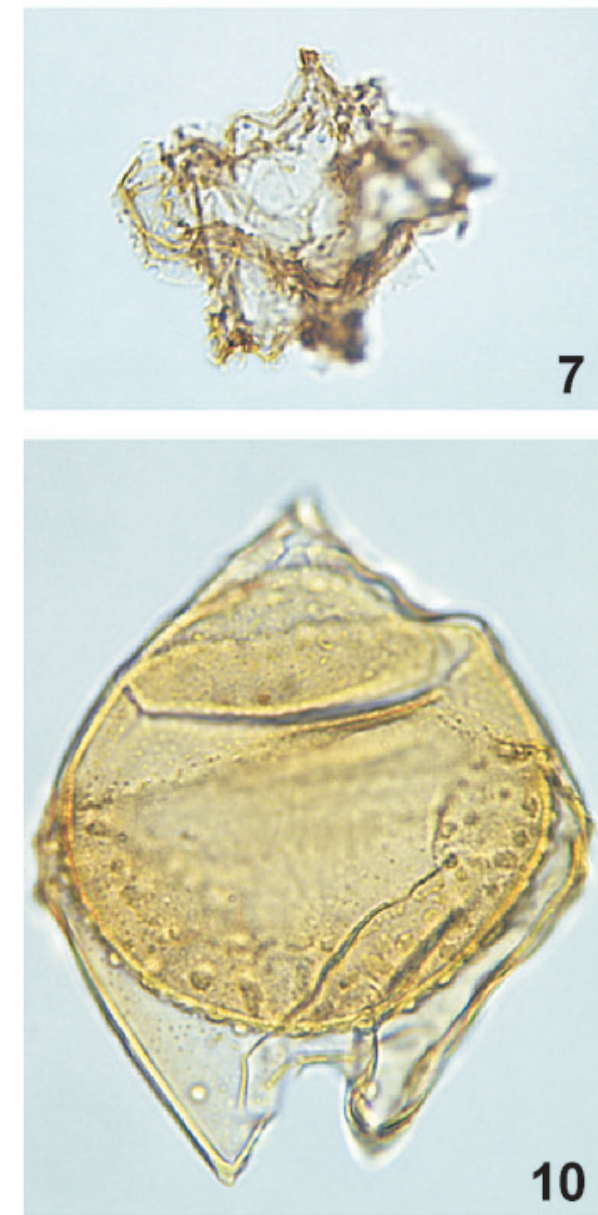

10
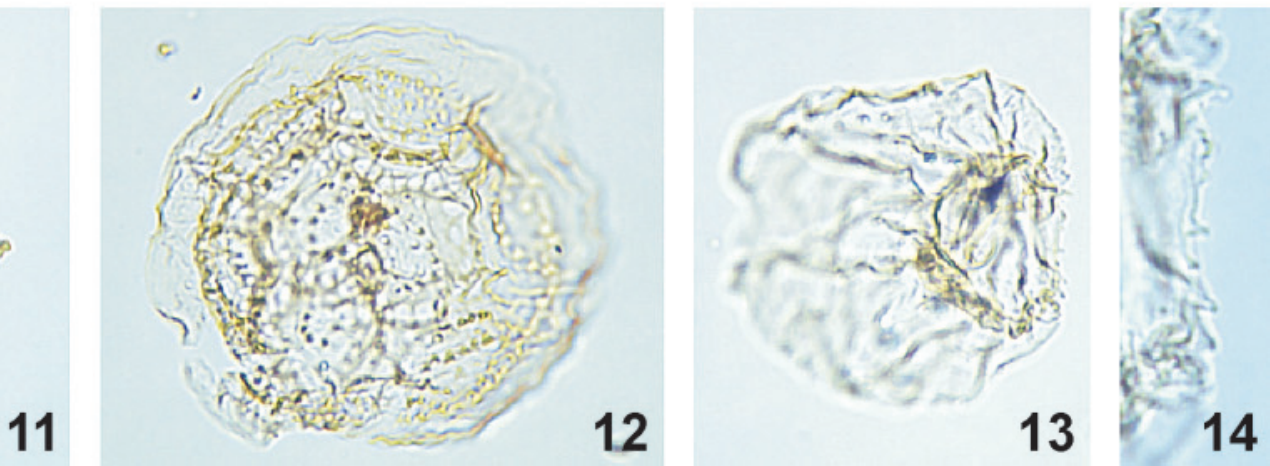

Plate 11. For full plate explanation see page 34. 

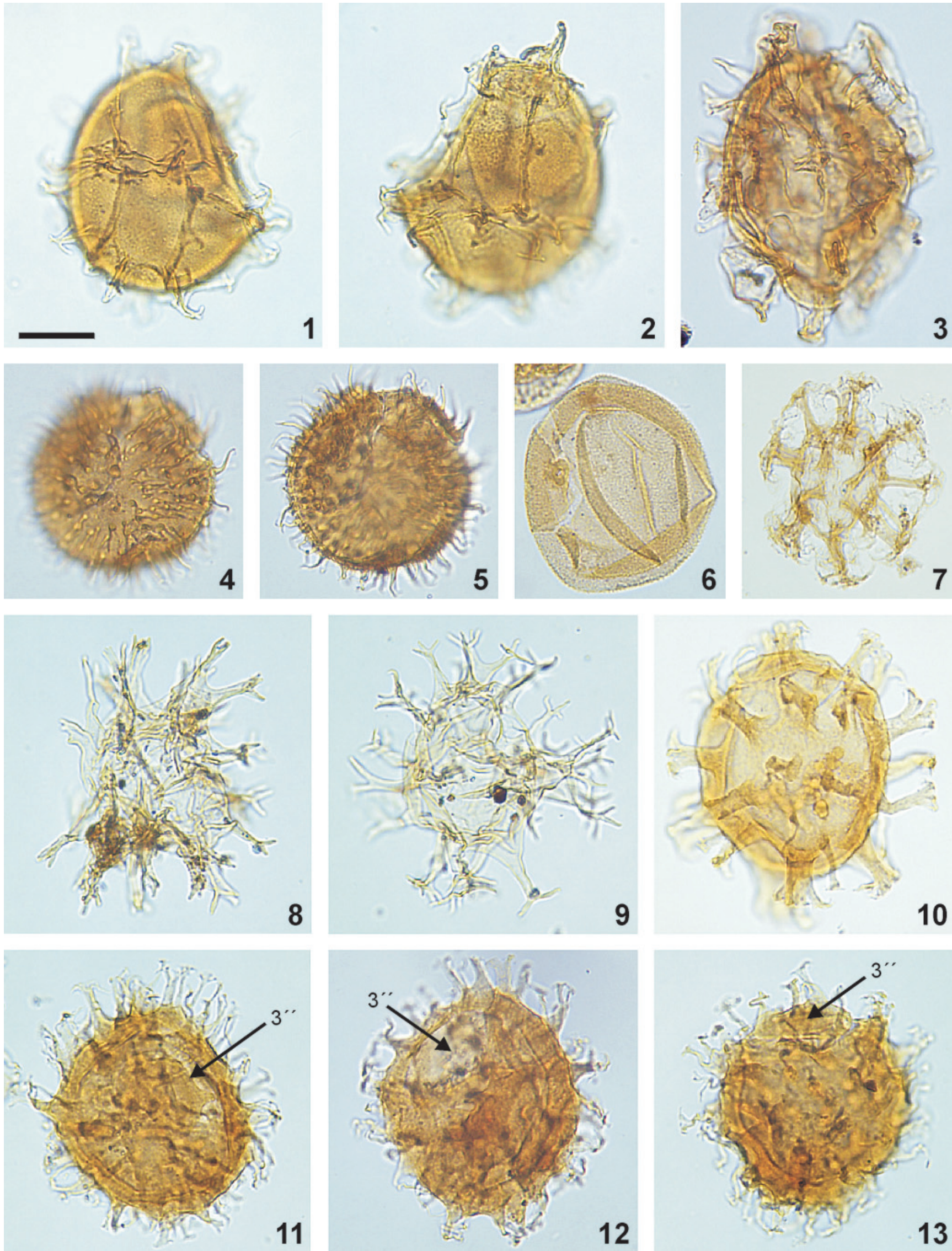

Plate 12. For full plate explanation see page 34. 

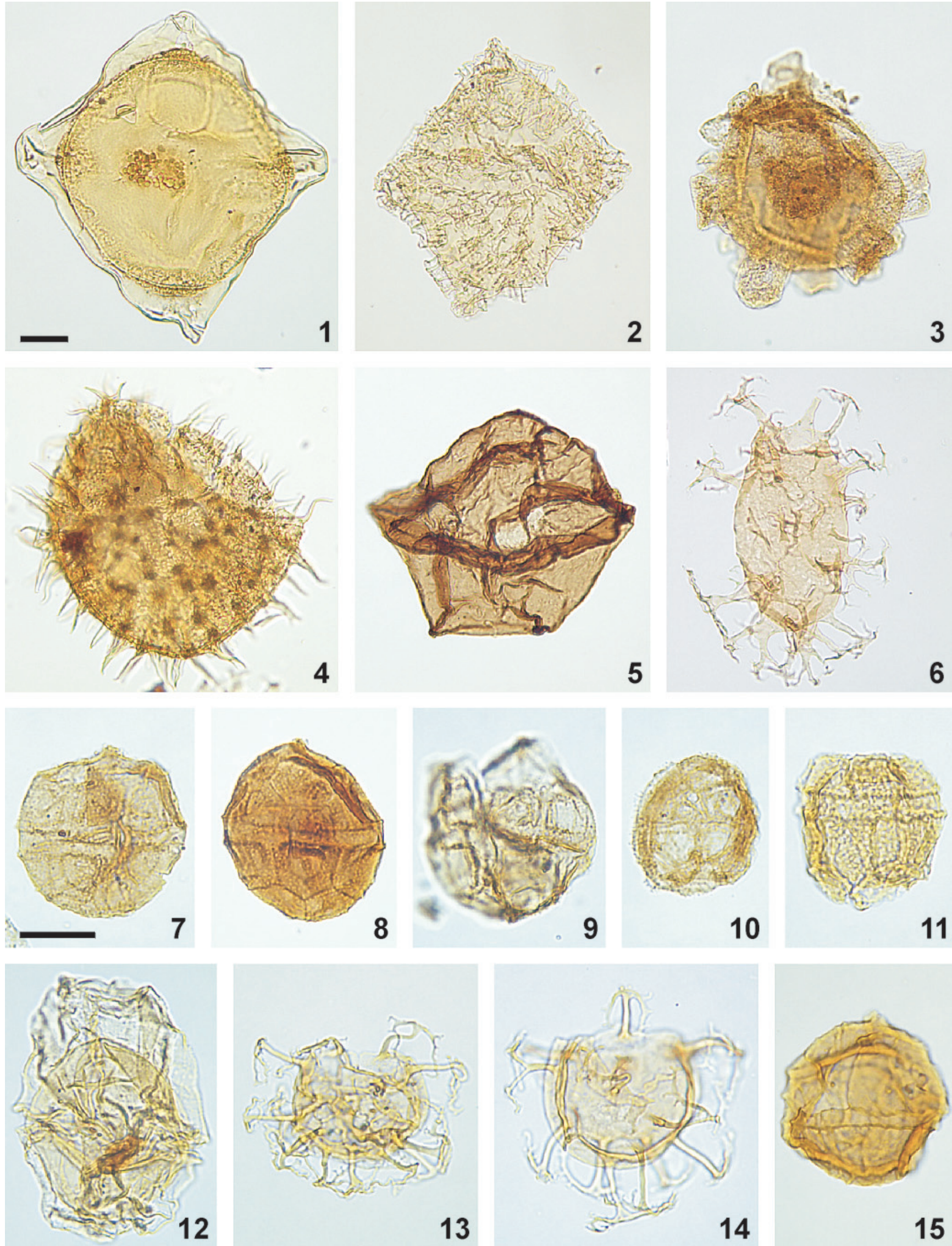

Plate 13. For full plate explanation see page 35. 

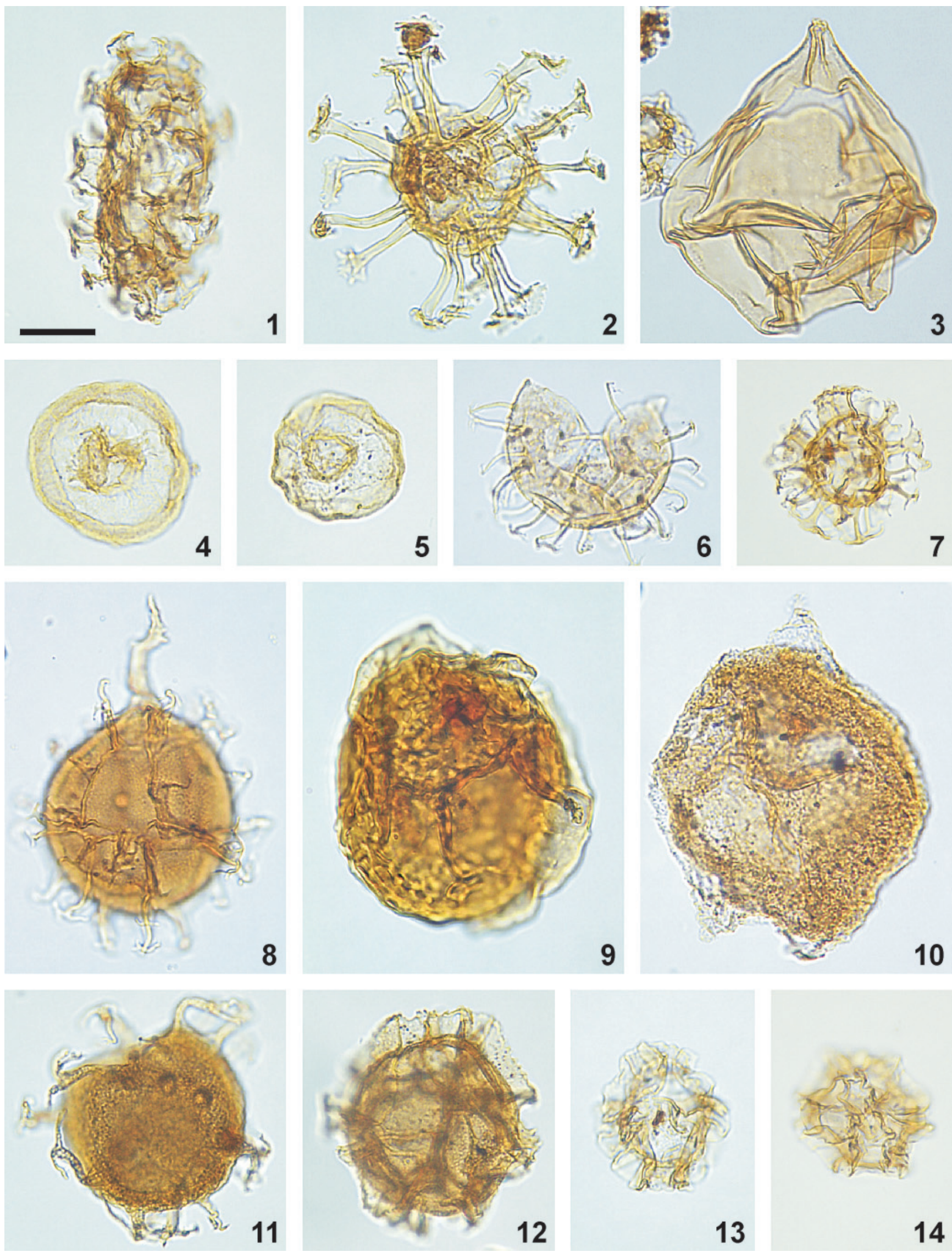

Plate 14. For full plate explanation see page 35. 

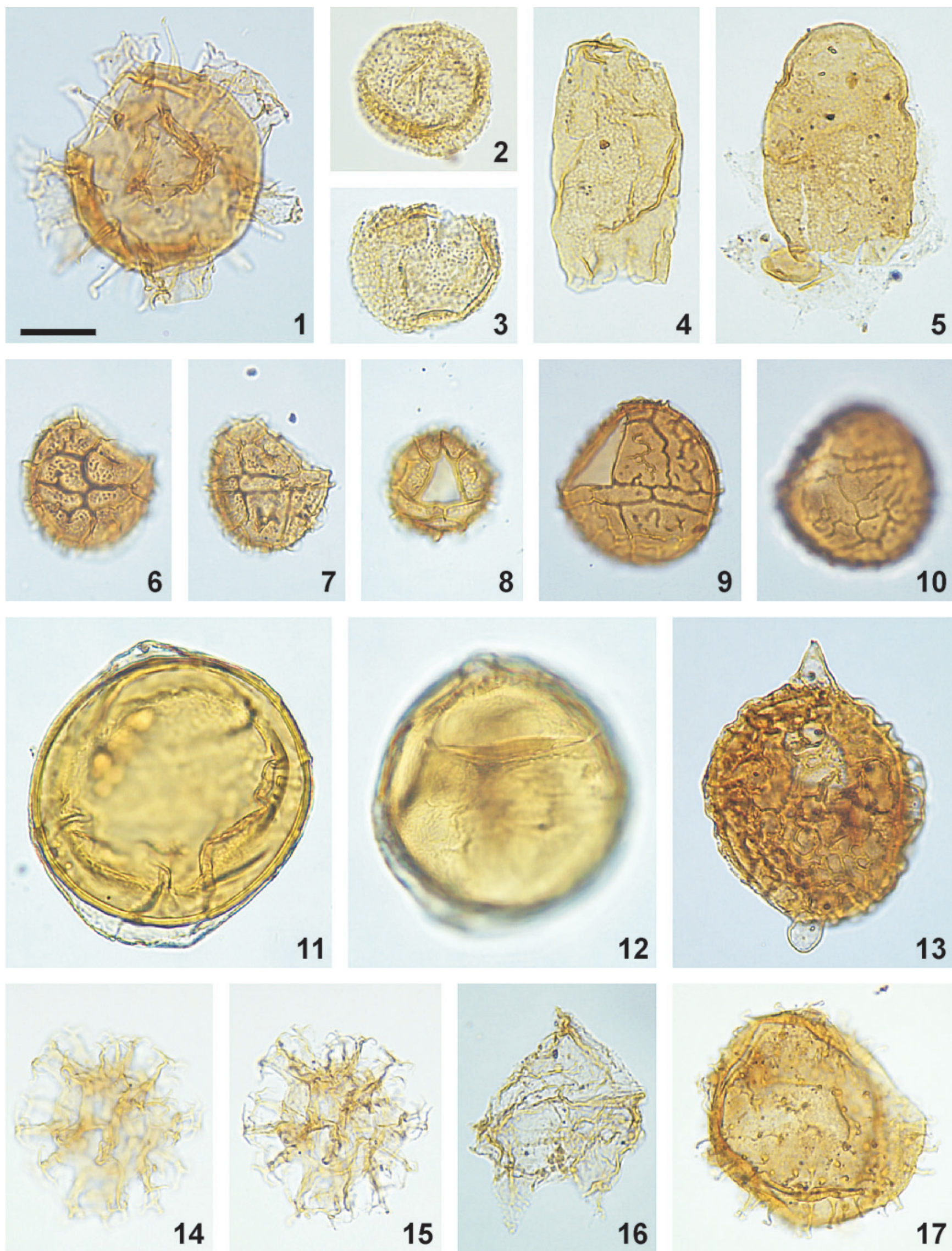

Plate 15. For full plate explanation see page 35. 

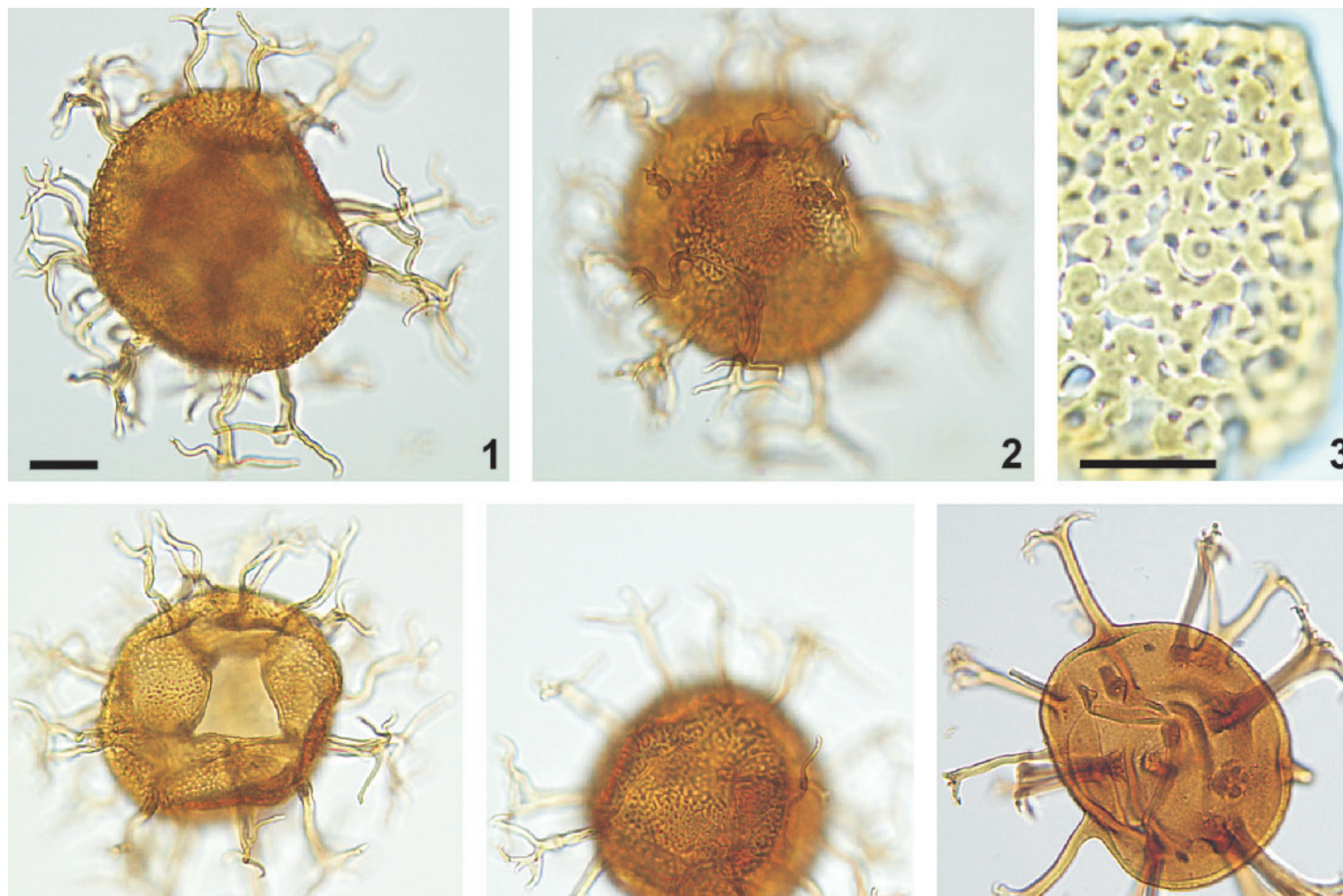

\section{4}
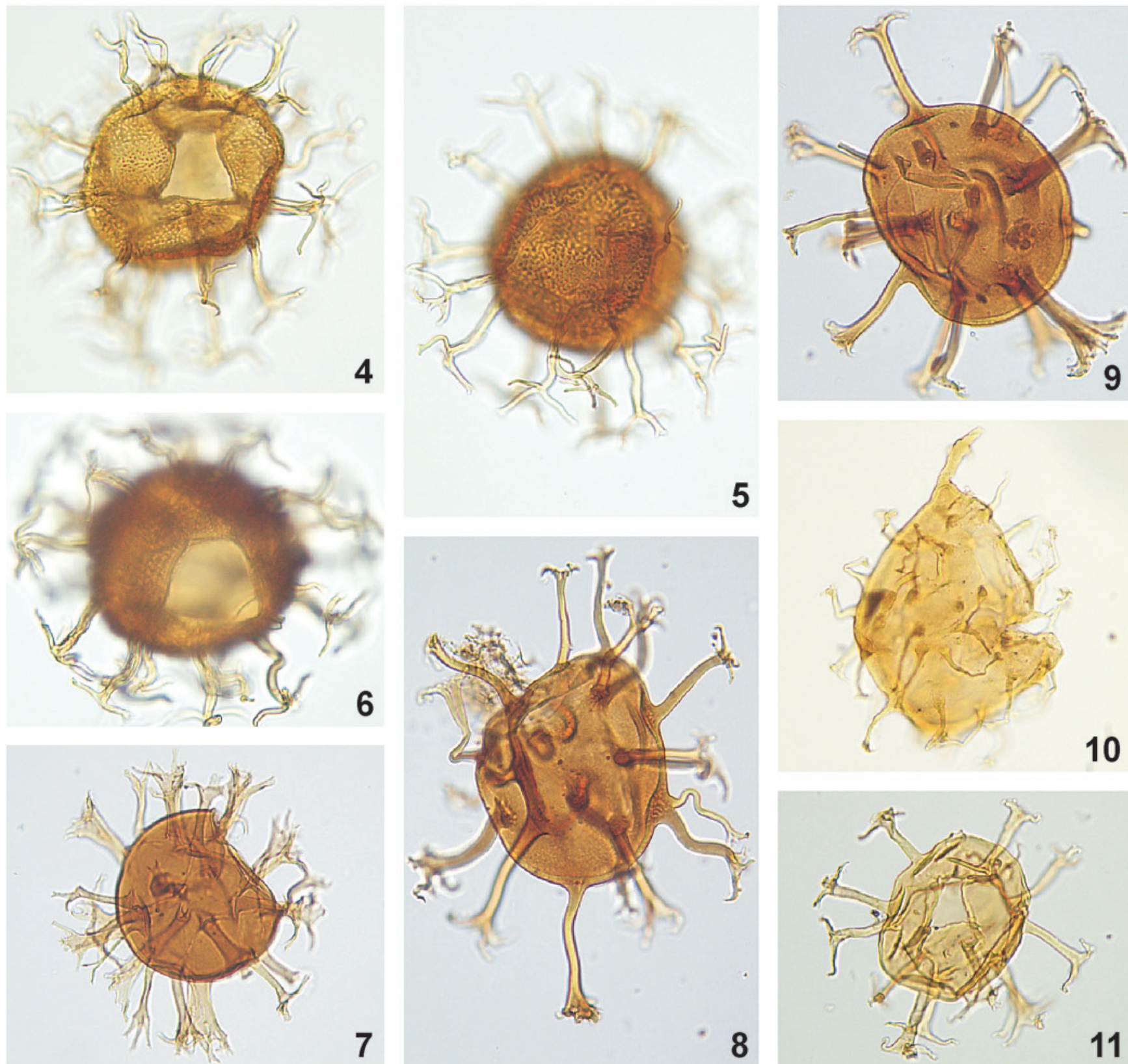

10

Plate 16. For full plate explanation see page 35.

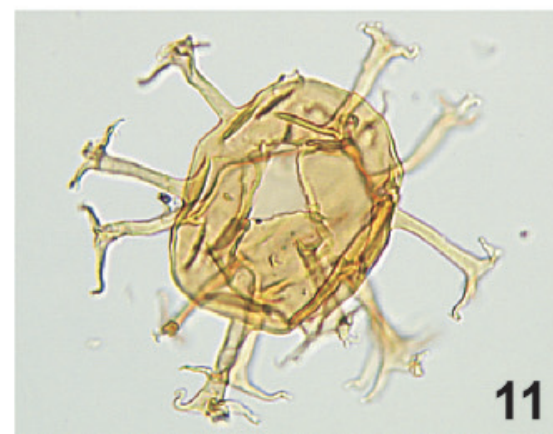



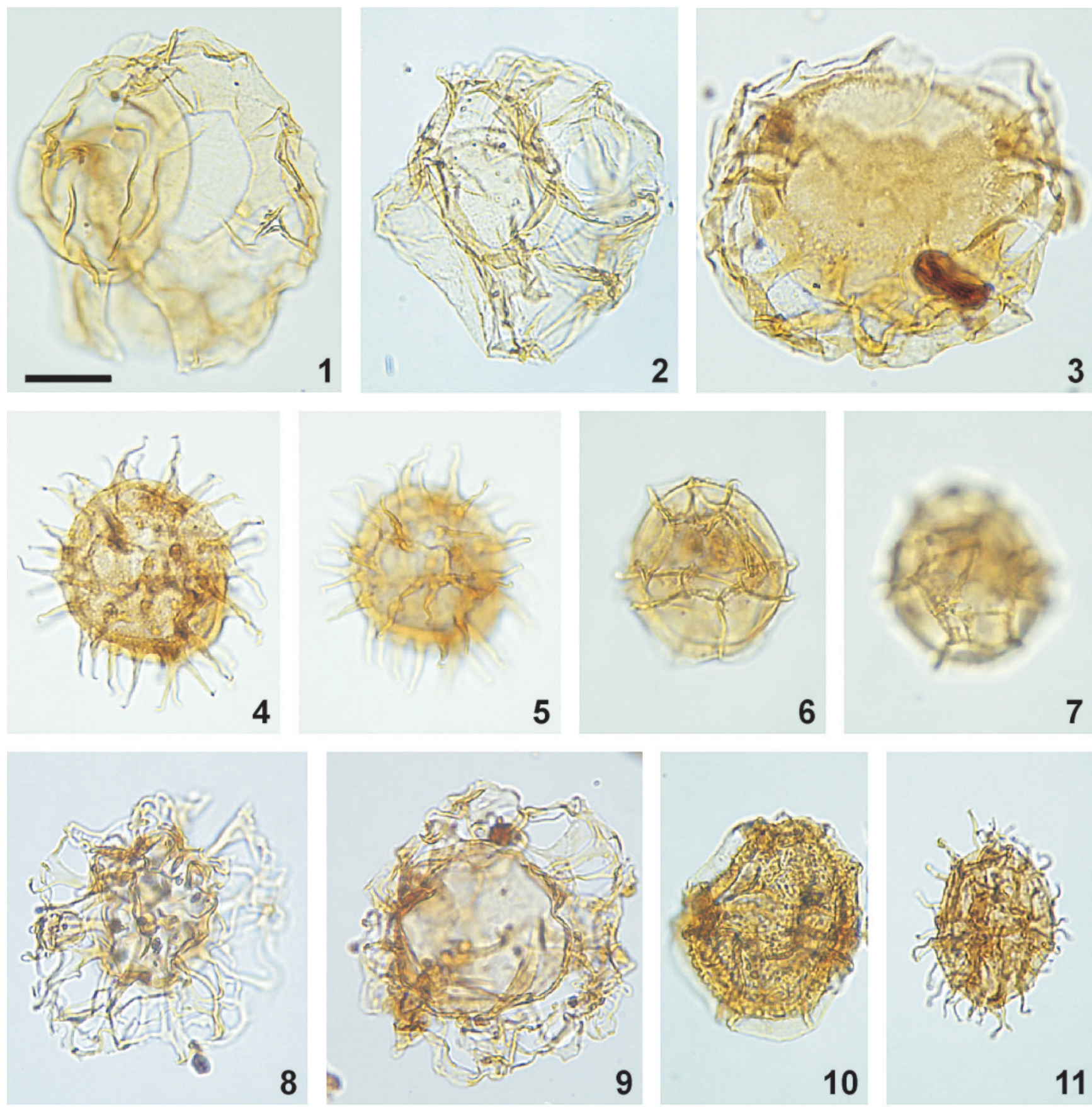

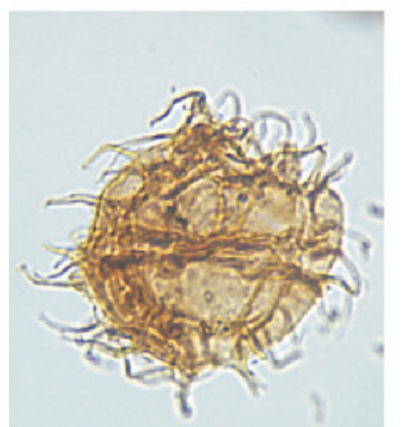

12

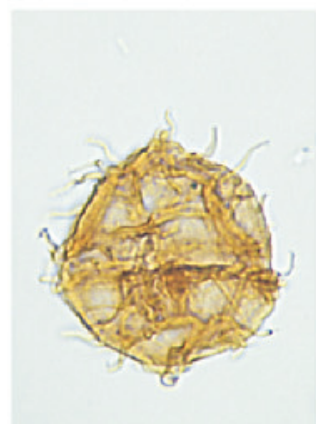

13

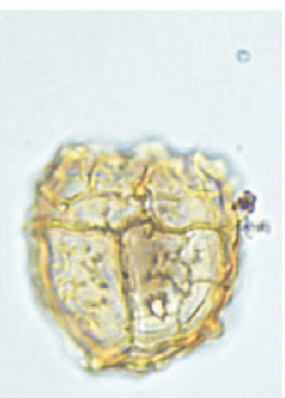

14
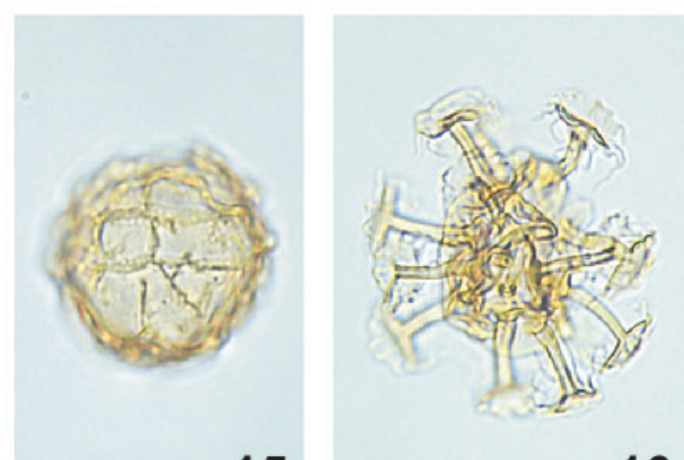

Plate 17. For full plate explanation see page 35.

15

16 

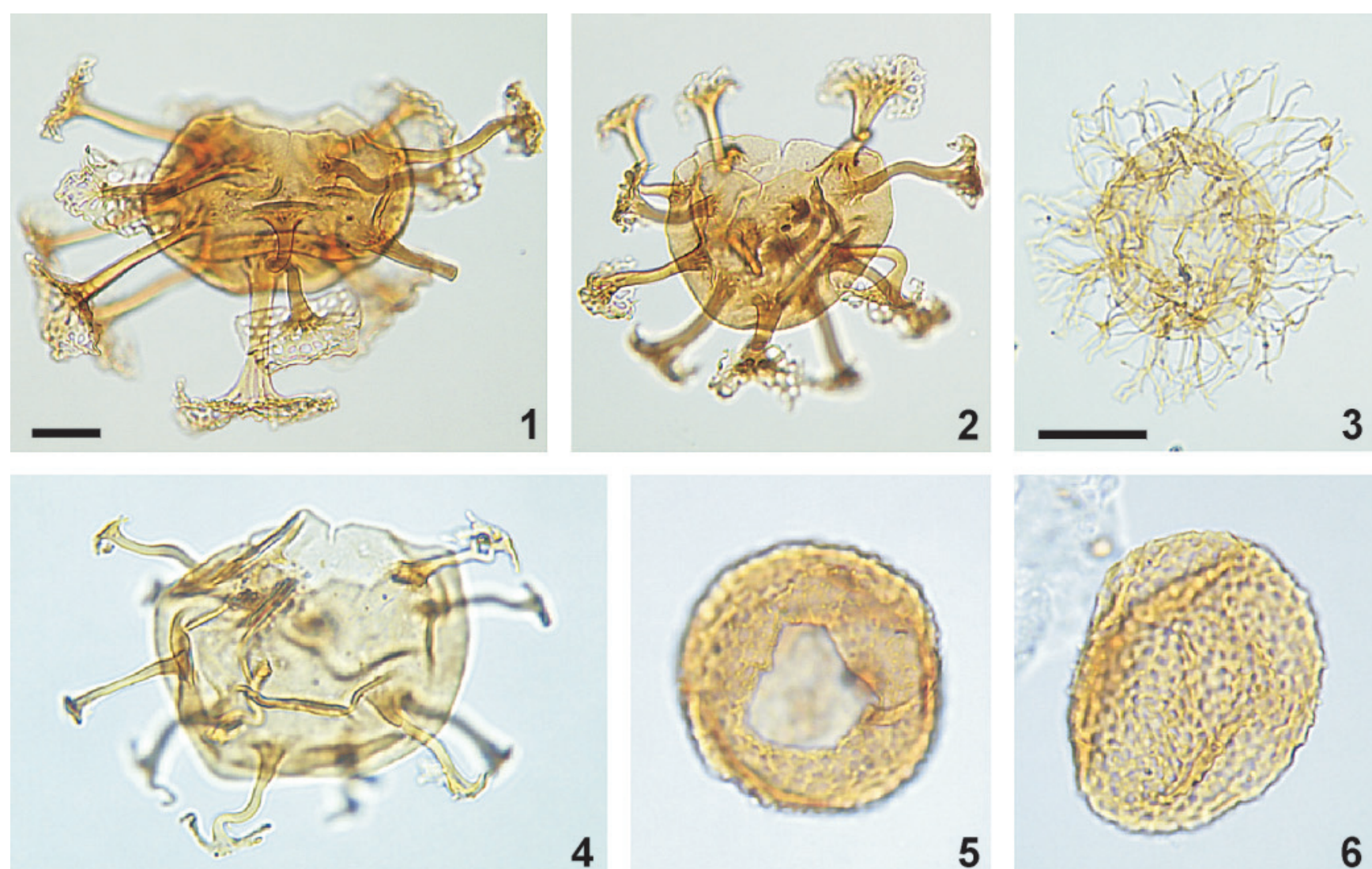

4
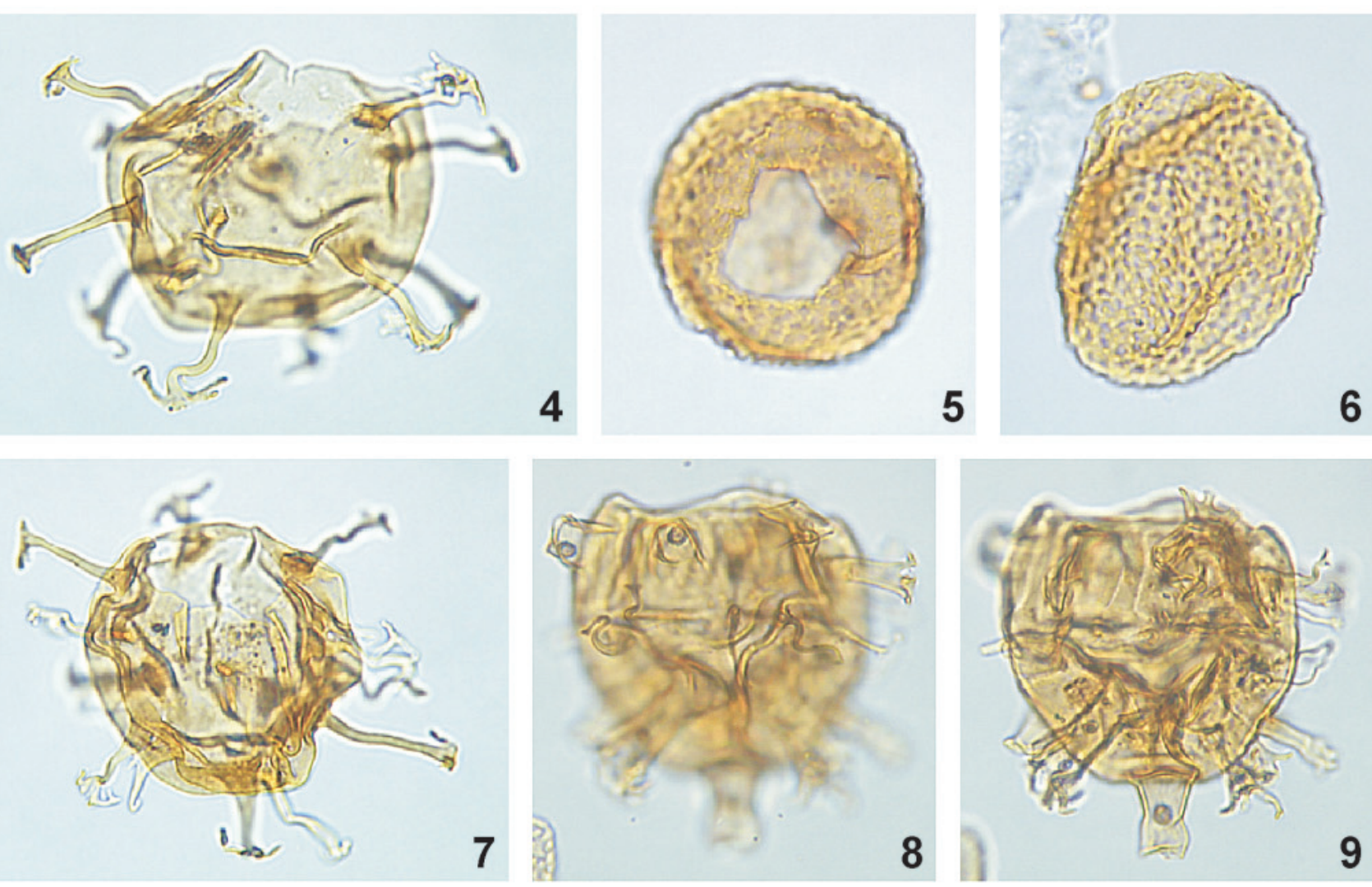

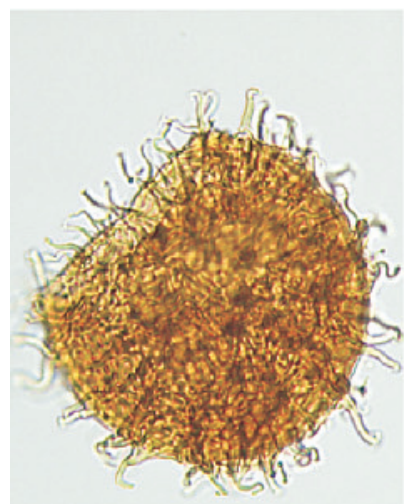

10

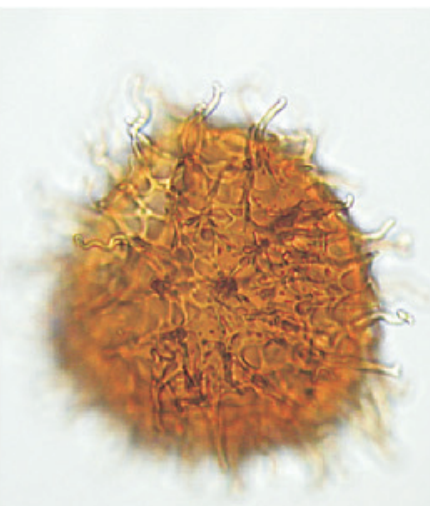

11

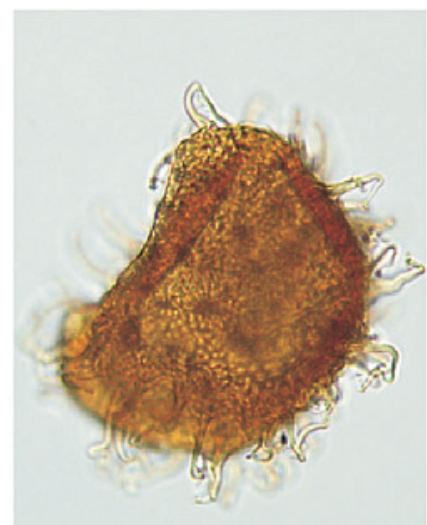

12

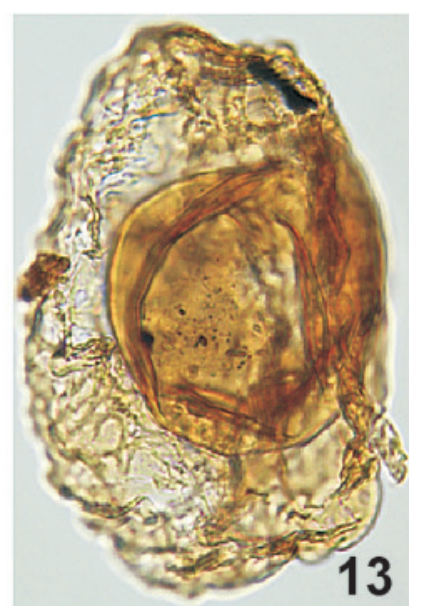

Plate 18. For full plate explanation see page 35. 

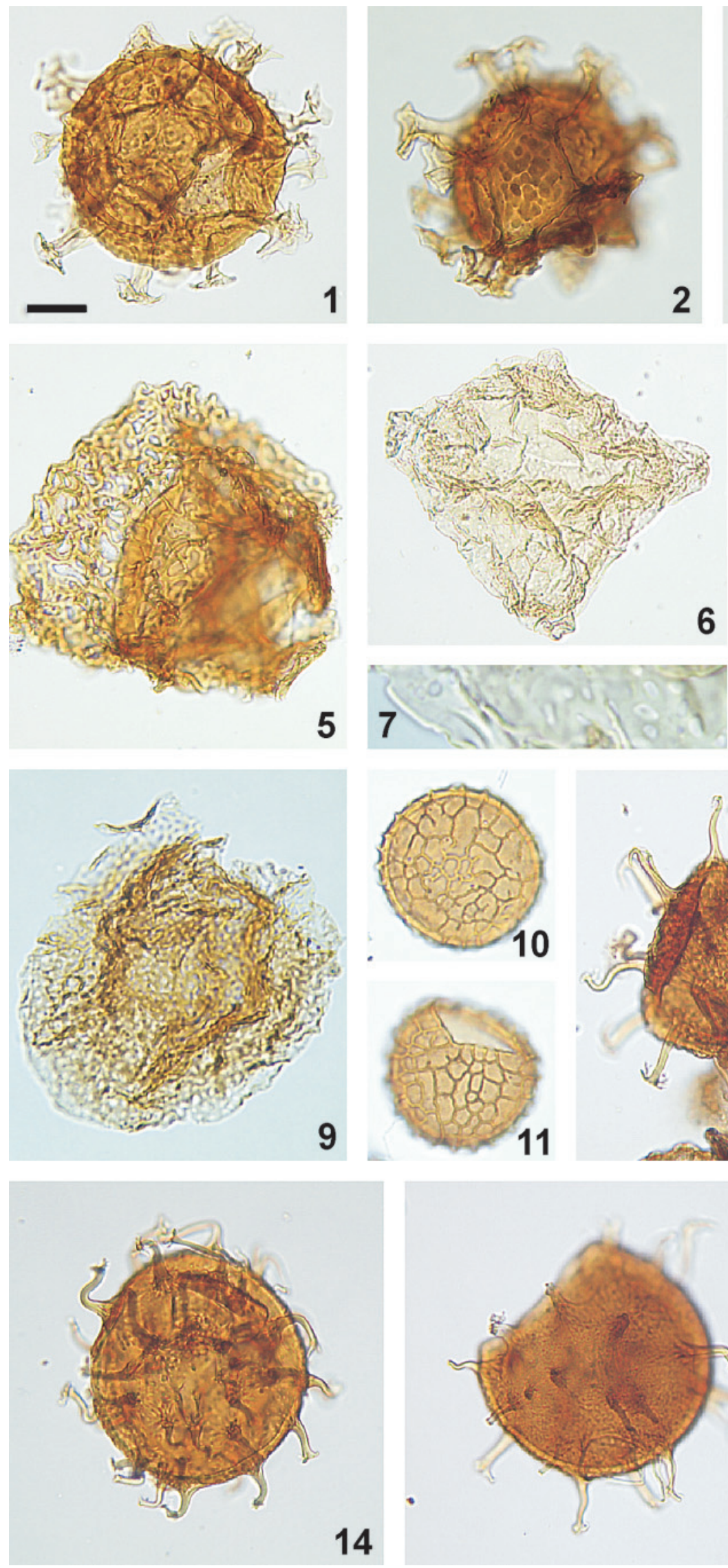

14
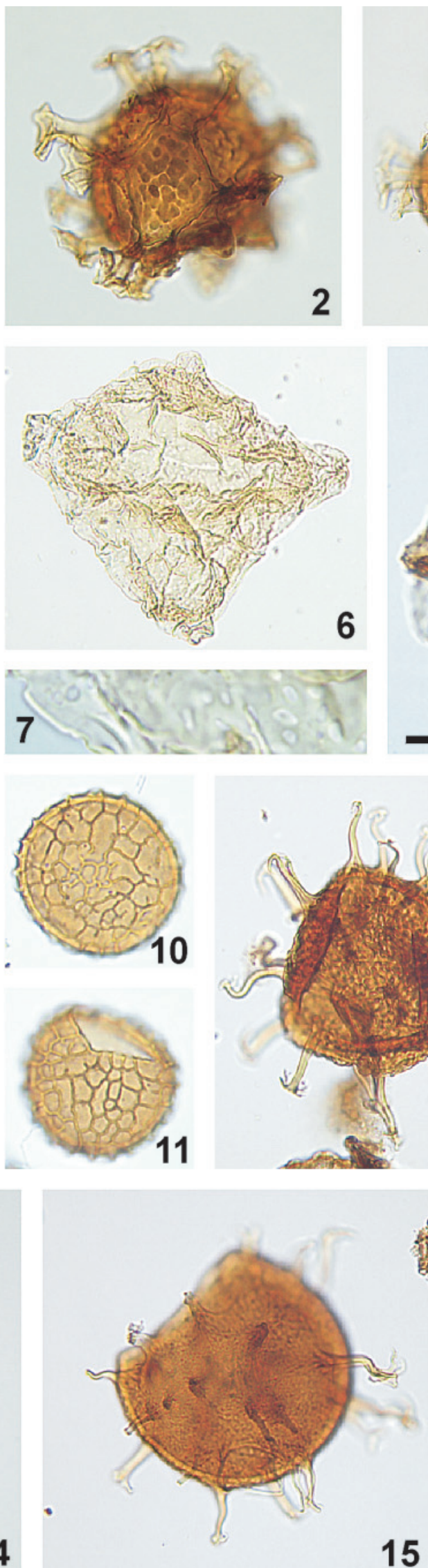
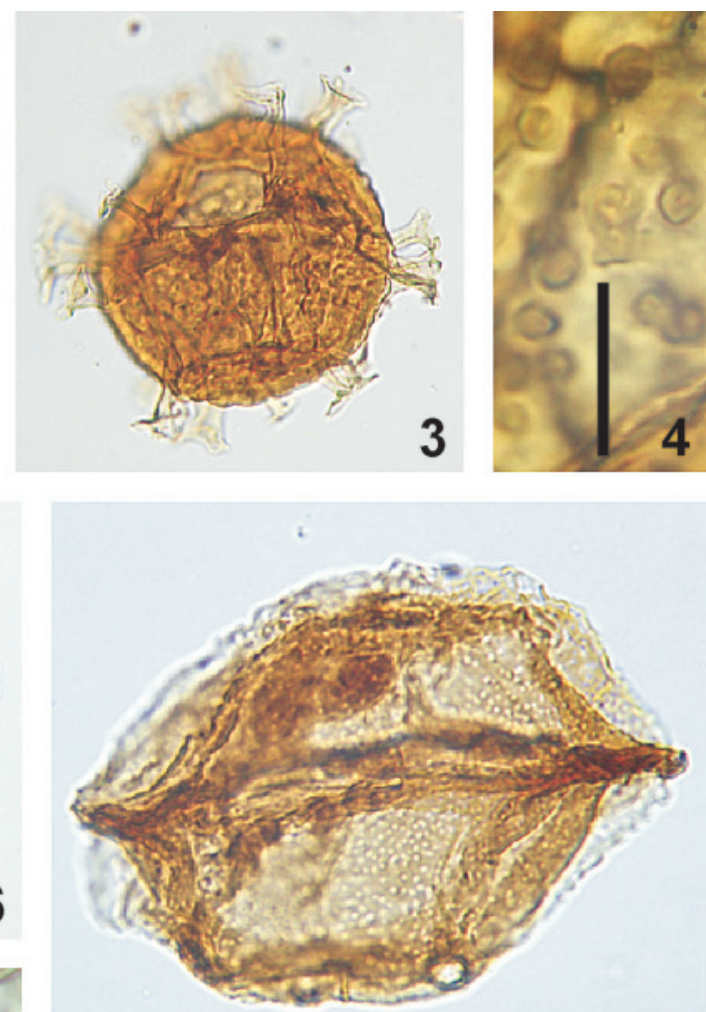

.8
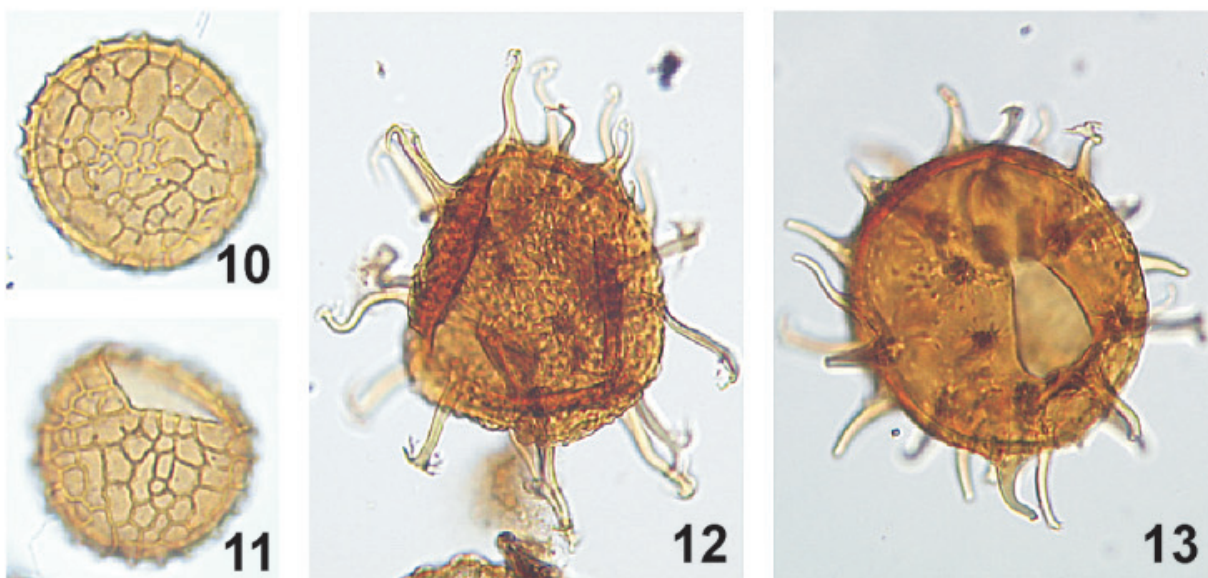

15

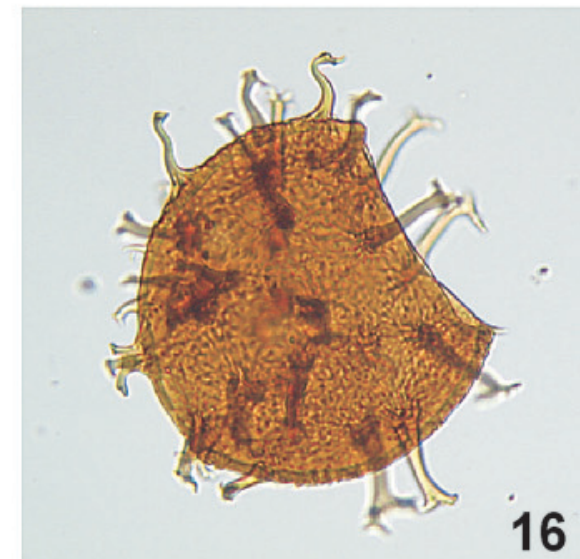

Plate 19. For full plate explanation see page 36. 


\begin{tabular}{ll}
\hline Series/Stage & First downhole occurrence (FDO) event \\
\hline Burdigalian (top not seen) & Saturnodinium sp. 1 \\
& Hystrichokolpoma cinctum \\
& Tityrosphaeridium cantharellus \\
& 'Hystrichokolpoma reductum' of Z. \& S. \\
& in Zevenboom, 1995 \\
& Leptodinium italicum \\
& Brigantedinium? spp. \\
& Thalassiphora rota sp. nov. \\
& Tectatodinium sp. 1 of Châteauneuf, \\
& 1980 \\
& Thalassiphora pelagica \\
& Caligodinium amiculum \\
& Chiropteridium galea \\
& Chiropteridium lobospinosum \\
& Distatodinium biffii \\
Aquitanian & Cleistosphaeridium diversispinosum \\
& Pentadinium laticinctum granulatum \\
Chattian & Areoligera semicirculata \\
& Svalbardella cooksoniae \\
& Rhombodinium draco \\
& Phthanoperidinium amoenum \\
Rupelian & Spiniferella cornuta cornuta \\
& Achomosphaera alcicornu \\
& Spiniferites manumii comb. nov. \\
Phthanoperidinium comatum & Operculodinium divergens \\
Areosphaeridium diktyoplokum \\
Heteraulacacysta porosa \\
\hline
\end{tabular}

Note: these taxa are shaded in Figure 2 and underlined in Figure 4.

Table 1. List of key taxa from the Alma-1X well for US East Coast sections. This dinoflagellate succession is calibrated directly with the international chronostratigraphy by calcareous nannofossils and foraminifera. De Verteuil \& Norris (1996a) used the Miocene time-scale of Berggren et al. (1995) and showed that the Aquitanian-Burdigalian boundary is close to the HO of the dinoflagellate Caligodinium amiculum. Therefore, the top of the Aquitanian is placed at the FDO of C. amiculum, following de Verteuil \& Norris (1996a).

\section{RESULTS}

Key species from Alma-1X can be used to correlate the well succession (Fig. 2) with the zonation schemes of Costa \& Manum (1988), Köthe (1990), Powell (1992), de Verteuil \& Norris (1996a) and Mudge \& Bujak (1996). None of the existing zonation schemes allows for a detailed subdivision of the study interval. However, the event succession in Alma-1X indicates that a number of conspicuous dinoflagellate and acritarch events may be of potential use in a detailed subdivision of the Oligocene-Lower Miocene. The event succession comprises primary key FDOs (Table 1, underlined in Fig. 4, shaded in Fig. 2) and secondary, supporting FDOs (shown without underlining in Fig. 4). The key events have been selected based on ease of identification and persistency in occurrence. The secondary events seem to occur less persistently than the key events in the well, but potentially may still be used as supportive correlatives.

At the Eocene-Oligocene boundary, in the basal part of the studied section, a hiatus is indicated by the dinoflagellate data. The two Priabonian marker events, FDO Heteraulacacysta

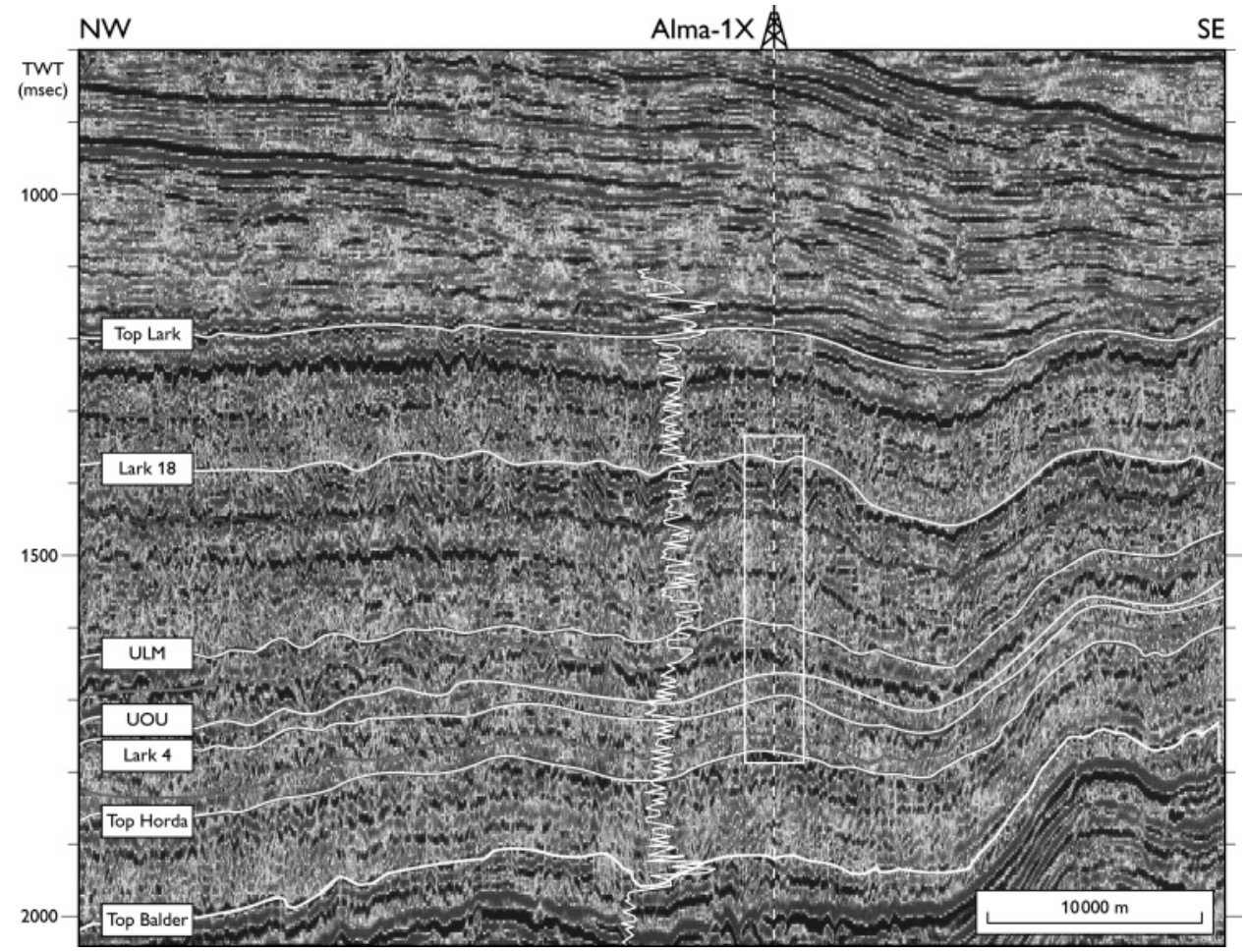

Fig. 3. Seismic section (from the seismic line RTD81-RE94-17B, see Fig. 1 for location) showing the position of Palaeogene marker horizons referred to in the text. The gamma log trace is superposed on the seismic section. A white frame indicates the study interval of the well. 
North Sea Oligocene-Lower Miocene dinoflagellates and acritarchs

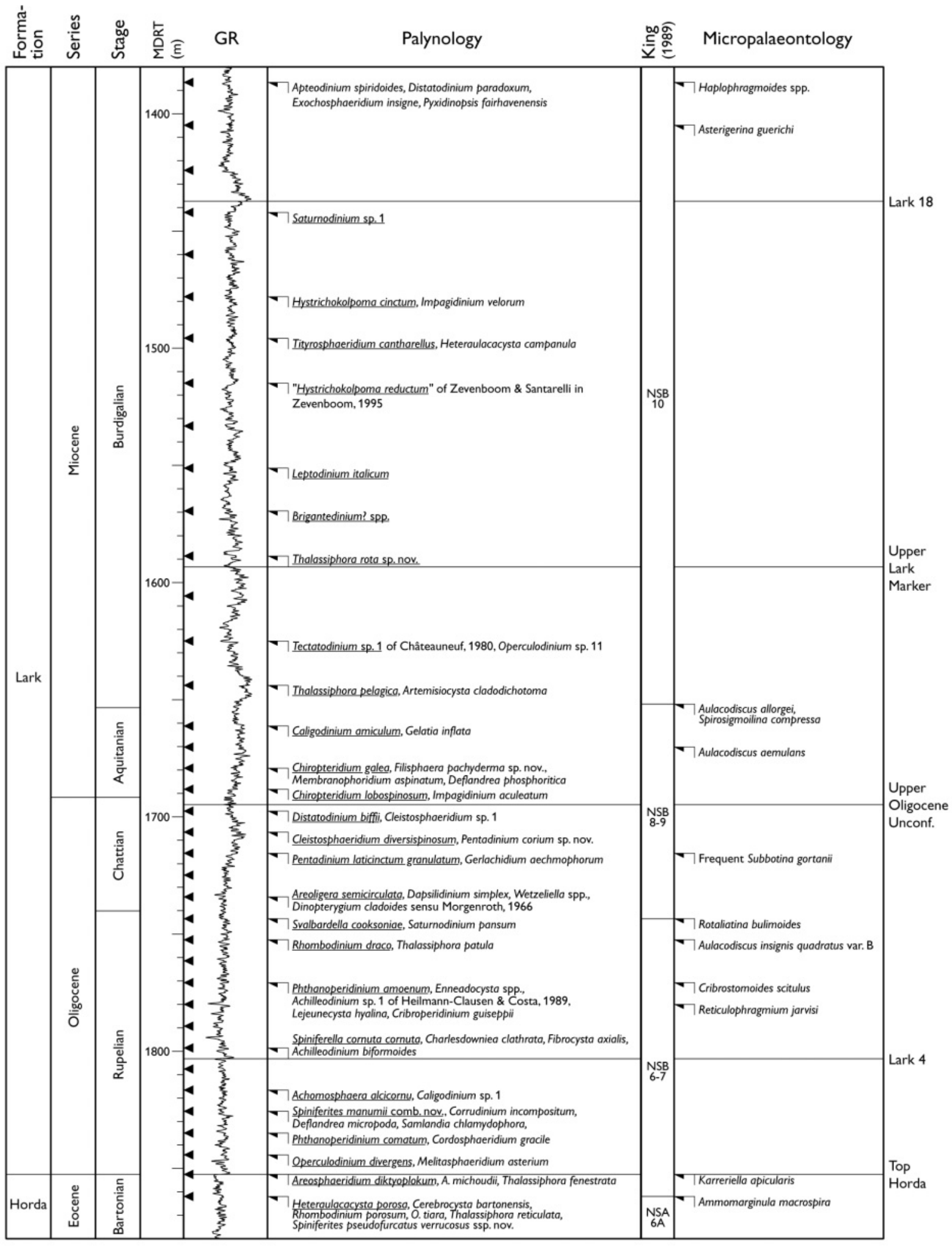

Fig. 4. Key biostratigraphic events (underlined) and secondary, supporting events (without underlining) from the Alma-1X well (see text for further explanation). The correlation with North Sea microfossil zones is based on unpublished well data from Robertson Group plc. and King (1989). 
porosa and FDO Rhombodinium porosum occur in the same cuttings sample as the FDO of Cerebrocysta bartonense, which marks the top of the Bartonian (upper Middle Eocene) according to Powell (1992) and Mudge \& Bujak (1996). Hence, that sample is considered of Bartonian age, and the Priabonian is either lacking or incomplete in the well. On the seismic section and on the gamma log the hiatus is represented by the Top Horda Marker.

Based on dinoflagellate biostratigraphy, the four seismic and log markers present above the Top Horda Marker can be dated as follows: Lark 4 Marker: intra-Rupelian; UOU Marker: uppermost Oligocene to lowermost Miocene; UL and Lark 18 markers: intra-Burdigalian (Fig. 4).

\section{DISCUSSION}

The present study demonstrates the potential for establishing a detailed subdivision of the Lower Miocene to Oligocene in the Central North Sea, based on FDOs of dinoflagellates and acritarchs. It is suggested that 26 key events may be of use in such a biostratigraphical subdivision (Table 1 and Figs 2, 4). The stratigraphical detail represented by the subdivision is comparable with that of the directly underlying PaleoceneEocene section (Mudge \& Bujak, 1996) and is much more detailed than established surrounding onshore zonation schemes. However, although the Lower Miocene-Oligocene of the Alma-1X well is considered fairly complete, hiati may be present in connection with the five seismic and log markers present in the interval. More studies of North Sea wells are needed to clarify this point and to establish a formal zonal subdivision of the interval.

\section{SYSTEMATIC DESCRIPTIONS}

All type specimens are deposited in the type collection of the Geological Museum of Copenhagen, Denmark and were from the Alma-1X well (UTM 31 E 639612 m N 6150851 m), Danish North Sea. Depths quoted are below rotary table (cuttings samples).

Division Dinoflagellata (Bütschli, 1885) Fensome et al., 1993

Subdivision Dinokaryota Fensome et al., 1993 Class Dinophyceae Pascher, 1914

Subclass Peridiniphycidae Fensome et al., 1993

Genus Amphorosphaeridium Davey, 1969

Amphorosphaeridium? almae sp. nov. (Pl. 12, figs 11-13; Fig. 5)

Type species. Amphorosphaeridium fenestratum Davey, 1969.

Derivation of name. From the Alma-1X well.

Diagnosis. Proximochorate, gonyaulacoid cyst with a thick, fibrous wall and numerous apparently non-tabulate, solid, fibrous, flexuous, distally pointed or bifid to licrate, sometimes branched, processes. Archaeopyle precingular, type $\mathrm{P}_{3}{ }^{\prime \prime}$.

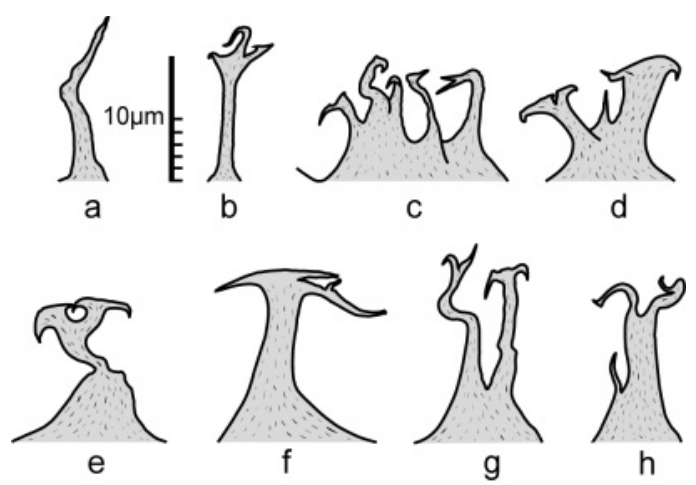

Fig. 5. Process variation in Amphorosphaeridium? almae sp. nov. See text for further explanation.

Paratypes. (1) MGUH 26746 (Pl. 12, fig. 12); (2) MGUH 26747 (P1. 12, fig. 13).

Horizon. Lark Formation, 5780-5810' (1761.7-1770.9 m). Upper Rupelian.

Description. Proximochorate, gonyaulacoid cyst of intermediate size (sensu Evitt, 1985), oval to sub-circular in outline. The number of wall layers could not be determined; the cyst probably has an autophragm. The cyst wall is fibrous and thick $(3-7 \mu \mathrm{m})$, its surface is densely pitted. Numerous $(>60)$, discrete, solid, fibrous, flexuous to anastomosing processes rise from the surface. The processes appear non-tabulate; however, they are often connected proximally by low ridges to form process rows or groups that may or may not reflect paratabulation. The processes may also be arranged in composite process groups (Figs 5c, d). Most processes have a broad base, but taper at half-length to become slender. Process shape varies on a specimen: ranging from simple and acuminate (Fig. 5a) over bifurcate to trifurcate (Fig. 5b) to licrate (Figs 5 d, e, f). Some processes branch at half-length or above to form two or more sets of tips (e.g. Pl. 12, fig. 12 at c. 2 o'clock, fig. 13 at 9 and 10 o'clock; Figs $5 \mathrm{e}, \mathrm{g}, \mathrm{h})$. The epicystal processes are usually slightly longer than those of the hypocystal area; the longest being those of the apex, the shortest being those in postcingular position. Process length variation may be from $5-15 \mu \mathrm{m}$ on a specimen. The overall process length is fairly constant in a population. The archaeopyle is precingular, presumably $\mathrm{P}_{3}$, , judged from its shape (Pl. 12, figs 11-13). The paratabulation is difficult to determine and may be indicated only by the archaeopyle and, on some specimens, possibly by rows or groups of processes.

Dimensions. Fifteen specimens were measured $(\mu \mathrm{m})$.

$\begin{array}{lll} & \text { Holotype } & \text { Range } \\ \text { Length } & 54 & 54(58) 62 \\ \text { Width } & 52 & 50(54) 58 \\ \text { Process length } & 8-13 & 5-15\end{array}$

Stratigraphical range. Middle to upper Rupelian in Alma-1X. 
Remarks. The new species resembles Amphorosphaeridium multispinosum (Davey \& Williams, 1966) Sarjeant, 1981 (especially specimens of that species figured by Jan du Chêne \& Adediran, 1985, pl. 14, figs 3, 4, 9), but differs by having more and shorter, flexuous processes. Amphorosphaeridium? almae differs from A. multibrevum Davey, 1969, which also has numerous processes (although not as many as the new species), in having solid, flexuous processes that terminate bifid to licrate, sometimes branching, instead of having hollow processes that are spinous distally. Amphorosphaeridium? almae resembles species of Cordosphaeridium and Fibrocysta in its wall structure and in having fibrous processes, but differs from species of Cordosphaeridium in having numerous, non-tabulate processes instead of the much fewer and tabulate processes characteristic of the latter genus. It differs from species of Fibrocysta in lacking polar protrusions, and from species of Exochosphaeridium in having complex process tips instead of the simple process tips typical of the latter genus. Specimens of Amphorosphaeridium typically have hollow processes and possess dictictive polar processes (Davey, 1969). As these characters are not typical for the new species, it is placed in Amphorosphaeridium with some hesitation.

Genus Dinopterygium Bujak, 1984 emend. Head, 1994

Dinopterygium cladoides sensu Morgenroth, 1966 (Pl. 11, figs 11-12)

Type species. Dinopterygium cladoides Deflandre, 1935

Remarks. The taxon resembles Heteraulacacysta fehmarnensis Lentin \& Williams, 1973, but differs in being smaller (size range of endocyst $47-53 \mu \mathrm{m}$ as opposed to $62-84 \mu \mathrm{m}$ for $H$. femharnensis), in having conspicuous paracingular septae and in having a coarser granulate to verrucate intratabular ornament.

Genus Filisphaera Bujak, 1984 emend. Head, 1994

Filisphaera pachyderma sp. nov.

(Pl. 6, figs 16-21)

Type species. Filisphaera filifera Bujak, 1984 emend. Head, 1994

Derivation of name. Greek: $\pi \alpha \chi v$, thick; $\delta \varepsilon ́ \rho \mu \alpha$, skin. With reference to its thick cyst wall.

Diagnosis. Gonyaulacoid autocyst with an extremely thick autophragm consisting of a thin pedium and a very thick luxuria composed of a dense mat of slightly anastomosing fibrils that radiate outwards from the pedium. The archaeopyle is precingular, type $\mathrm{P}_{3}$. . The cyst lacks any indication of paratabulation other than the archaeopyle.

Holotype. MGUH 26751, SM 320 (P1. 6, figs 17-20).

Paratypes: (1) MGUH 26752, SM 319 (Pl. 6, fig. 16); (2) MGUH 26753, SM 302 (Pl. 6, fig. 21).

Horizon. Lark Formation, 5480-5510' (1670.3-1679.4 m). Lower Aquitanian.
Description. Small to intermediate-sized autocyst, sub-circular to oval in outline. The cyst wall is extremely thick and composed of two wall layers; a thin, smooth pedium (less than $0.5 \mu \mathrm{m}$ thick) and a very thick luxuria (thickness: $8-12 \mu \mathrm{m}$ ). The luxuria is composed of closely spaced fibrils radiating out from the pedium to form a dense mat on the cyst. Each fibril seems to be slightly flexuous to anastomosing from its base to its tip (Pl. 6, fig. 20). The luxuria is finely granulate to pitted in surface view (Pl. 6, fig. 19). The archaeopyle is precingular, type $\mathrm{P}_{3^{\prime \prime}}$, judged from its shape. Apart from the archaeopyle, the cyst lacks indications of paratabulation. In a population, cyst size and wall thickness varies only very little, whereas the overall shape may vary from being circular to oval. When oval, the long axis may be either polar or equatorial, resulting in specimens being either higher than broad (Pl. 6, fig. 21), or broader than high (Pl. 6, fig. 16). The former shape is the most common by far.

Dimensions. Fifteen specimens were measured $(\mu \mathrm{m})$

$\begin{array}{lll} & \text { Holotype } & \text { Range } \\ \text { Length } & 47 & 45(52) 57 \\ \text { Width } & 52 & 38(46) 57 \\ \text { Wall thickness } & 8 & 8(10) 12\end{array}$

Stratigraphical range. Chattian to lower Aquitanian in the Alma-1X well.

Remarks. Filisphaera pachyderma differs from F. filifera Bujak, 1984 emend. Head, 1994 and from most other small to intermediate-sized dinoflagellate cysts with fibrous cyst wall ornament and a type $\mathrm{P}$ archaeopyle in its much thicker luxuria. Some specimens of Tectatodinium pellitum Wall, 1967 emend. Head, 1994 may possess a thick cyst wall, having a superficial resemblance with the new species, but they differ in having an interconnecting, irregular, 'spongy' and lanate luxuria instead of the radiating, fibrous luxuria of $F$. pachyderma (see Head, 1994, for discussion of luxuria morphology in the genera Tectatodinium and Filisphaera).

Genus Pentadinium Gerlach, 1961 emend. Benedek et al., 1982

Pentadinium corium sp. nov. (Pl. 8, figs 11-12, 16-18; Fig. 6)

Type species. Pentadinium laticinctum Gerlach, 1961 emend. Benedek et al., 1982.

Derivation of name. Latin: corium, -ii, thick skin. With reference to its thick endophragm.

Diagnosis. Suturocavate, gonyaulacoid cyst with a thick, spongy endophragm and a thin periphragm that forms very low, ondulating, parasutural ridges on the endophragm. Archaeopyle precingular, type $\mathrm{P}_{3}$."

Holotype: MGUH 26754, SM 510 (P1. 8, figs 17-18).

Paratypes. (1) MGUH 26755 (Pl. 8, fig. 11); (2) MGUH 26756, SM 458 (Pl. 8, fig. 12). 


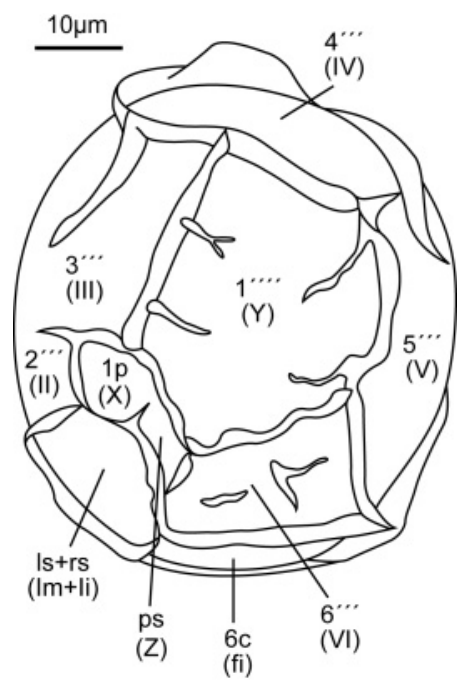

Fig. 6. Exterior view of hypocyst of Pentadinium coriumsp. nov. (LVR 21478, specimen also shown in Pl. 8, fig. 11). The line drawing shows the sexiform gonyaulacoid tabulation pattern. Interpreted plates in Kofoid notation, Taylor-Evitt notation in brackets.

Horizon. Lark Formation, 5630-5660' (1716.0-1725.2 m). Middle Chattian.

Description. Small to intermediate-sized suturocavate, gonyaulacoid cyst. The cyst is circular to sub-circular in outline and is composed of two wall layers. The endophragm is thick $(4-5 \mu \mathrm{m})$, 'spongy' and lanate in cross-section, finely pitted and granulate in surface view. The periphragm is thin and smooth (periphragm thickness: $<0.25 \mu \mathrm{m})$. The endophragm and periphragm are closely appressed except where the periphragm rises to form low, slightly ondulating, cavate ridges on the endophragm (ridge height: $1-3 \mu \mathrm{m})$. The ridges are generally parasutural, but small, accessory, cavate folds often extend from the parasutural ridges some distance onto the paraplates (Fig. 6). Small, discrete, cavate folds may also raise in intratabular position (Fig. 6). The archaeopyle is precingular, type $\mathrm{P}_{3^{\prime \prime}}$. The paratabulation is only incompletely indicated by parasutural folds on the periphragm. It is often masked by accessory folds in the periphragm and by the dark-coloured thick endophragm. When visible, the paratabulation is gonyaulacoid, S-type sexiform with the plate

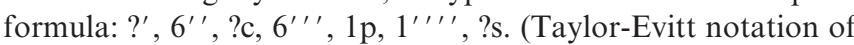
the hypocyst is shown in Fig. 6.)

Dimensions. Fifteen specimens were measured $(\mu \mathrm{m})$.

$\begin{array}{lll} & \text { Holotype } & \text { Range } \\ \text { Length } & 53 & 44(50) 56 \\ \text { Width } & 46 & 45(48) 52 \\ \text { Sutural ridge height } & 2 & 2-3\end{array}$

Stratigraphical range. Rupelian to Chattian in the Alma-1X well.

Remarks. Pentadinium corium is distinguished from most other species of the genus Pentadinium by its smaller size, its low parasutural ridges and the 'spongy' and lanate structure of the endocyst wall. Pentadinium favatum Edwards, 1982, $P$. goniferum Edwards, 1982 and P. membranaceum (Eisenack, 1965) Stover \& Evitt, 1978 all have a relatively thick, finely ornamented endocyst wall, but differ in being bigger and in having much higher parasutural ridges (crests). Pentadinium favatum differs further in having a meshlike, perforate periphragm. The new species resembles species of the genera Impagidinium and Leptodinium that possess a thick cyst wall (e.g. Impagidinium pentahedrias Damassa, 1979; Leptodinium clathratum (Cookson \& Eisenack, 1960) Sarjeant in Davey et al., 1969), but it differs in possessing a periphragm that forms cavate parasutural and intraplate ridges.

Genus Spiniferites Mantell, 1850, emend Sarjeant, 1970

Spiniferites manumii (Lund, 2002) comb. nov.

(Pl. 16, figs 1-6)

Type species. Spiniferites ramosus (Ehrenberg, 1838) Mantell, 1854.

Basionym. Pseudospiniferites manumii Lund, 2003, Northern European Cenozoic Stratigraphy; Proceedings $8^{\text {th }}$ Biannual meeting RCNNS/RCNPS, Flintbek, Germany: 83-89, pl. 1, figs 1-9; holotype sample R23, pl. 1, figs 1-2.

Emended diagnosis. Large skolochorate, spiniferate, gonyaulacoid cyst with smooth, slender and usually flexuous to sinuous processes and a conspicuous closely spaced vermiculate surface ornament.

Emended description. Large, skolochorate, spiniferate, gonyaulacoid cyst. The processes are gonal, simple and branch distally in a trifid manner, and are smooth, slender and usually flexuous to sinuous. The cyst body is ornamented heavily with closely spaced vermiculae (width of vermiculae: $1-3 \mu \mathrm{m}$ ). Low parasutural crests connect the processes proximally. The crests are embedded in the surface ornament and only discernible under high magnification appearing as low, straight structures connecting the process bases. The archaeopyle is precingular, type $\mathrm{P}_{3^{\prime \prime}}$. The paratabulation is sexiform gonyaulacoid: $3^{\prime}$, $5-6^{\prime \prime}, 6 \mathrm{c}, 5^{\prime \prime \prime}, 1 \mathrm{p}, 1^{\prime \prime \prime \prime}$, ?s, shown by parasutural ridges and gonal processes.

Stratigraphical range. Uppermost Bartonian to lower Rupelian in Alma-1X. In Alma-1X, the FDO of the taxon is recorded at the same stratigraphic level as that observed by Lund (2002), Manum et al. (1989) and Williams \& Manum (1999), i.e. in the lower Rupelian, below the FDO of Enneadocysta pectiniformis and above the FDO of Areosphaeridium diktyoplokum. Its occurrence pattern thus confirms the observation that the species constitutes an important intra-Rupelian stratigraphic marker (Lund, 2002).

Remarks. The prime reason for Lund (2002) establishing the new genus Pseudospiniferites was the 'tendency towards suture break-up around the primary single plate precingular archeopyle'. However, Lund also stated that these accessory 
archaeopyle sutures occur only sporadically in a cyst population (Lund, 2002, p. 87). Three of his illustrated specimens are, indeed, ruptured cysts (Lund, 2002, pl. 1, figs 1, 2, 4, 7), one is a fragment (Lund, 2002, pl. 1, fig. 3) and two (Lund, 2002, pl. 1, figs 5,6$)$ are intact. The taxon is well known from North Sea boreholes, occuring in various states of preservation. The population encountered in Alma-1X occurs at the same stratigraphical level as the specimens described by Lund and is dominated by well-preserved specimens that do not show signs of accessory archaeopyle sutures. The specimens figured by Manum et al. (1989) from ODP Site 643 and by Williams \& Manum (1999) from ODP Site 908 - both Norwegian Sea - are intact and also lack accessory archaeopyle sutures. Therefore, the character stressed as a criterion for establishing a new genus is believed to be a preservation artefact.

The generic diagnosis of the genus Pseudospiniferites also includes the presence of granulate to (micro) reticulate surface ornament (Lund, 2002, p. 87). However, the emended diagnosis of the genus Spiniferites allows for such surface ornament (Sarjeant, 1970, p. 75) and several recognized species have an ornamented surface.

The specimens observed from Alma-1X, those figured by Manum et al. (1989), Williams \& Manum (1999) and illustrated by Lund $(2002$; figs 5, 6) from the North Sea all have at least some flexuous processes. Although most processes on the holotype are straight, some are flexuous (Lund, 2002, pl. 1, figs 1, 2). As all the specimens mentioned above are undoubtedly conspecific, the description of the taxon is widened to allow for specimens with flexuous processes.

The species is transferred to Spiniferites Mantell, 1850 as a species of that genus characterized by its large size, conspicuous closely spaced vermiculate ornament and the presence of flexuous to sinuous processes.

Spiniferites pseudofurcatus (Klump, 1953) Sarjeant, 1970 emend. Sarjeant, 1981

Spiniferites pseudofurcatus verrucosus ssp. nov. (Pl. 19, figs 1-4)

Derivation of name. Latin: verrucosus, $-a$, -um, warty. With reference to the characteristic ornamentation on the endophragm.

Diagnosis. Skolochorate, spiniferate, gonyaulacoid cyst of intermediate to large size. The processes terminate bifurcate to tetrafurcate or ramify. Low septal crests connect the processes proximally. The periphragm is smooth, the endophragm is coarsely verrucate to vermiculate.

Holotype. MGUH 26757, SM 501 (Pl. 19, fig. 2).

Paratypes. (1) MGUH 26758 (Pl. 19, fig. 1); (2) MGUH 26759 (Pl. 19, fig. 3).

Horizon. Horda Formation, 6080-6110' (1853.2-1862.3 m). Upper Bartonian.

Stratigraphical range. Uppermost Lutetian to Bartonian in Alma-1X (zones E6c-E7b of Mudge \& Bujak, 1996).

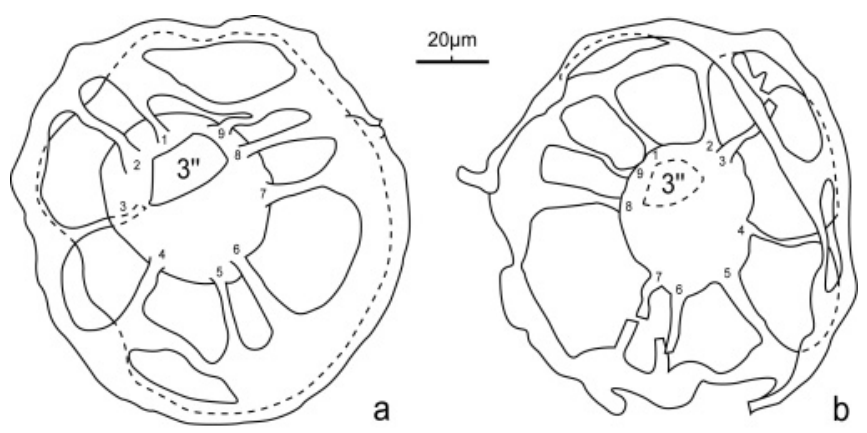

Fig. 7. Outline tracing of specimens of Thalassiphora rota sp. nov.: (a) LVR 24193, SM 452, holotype (also shown in Pl. 5, fig. 1), exterior view of dorsal surface; perimeter of large ventral opening in ectophragm dashed; (b) LVR 24222, paratype (also shown in Pl. 5, fig. 2); exterior view of ventral surface; archaeopyle and far rim of perforations in ectophragm dashed. For further explanation, see text.

Remarks. The new subspecies differs from the autotype Spiniferites pseudofurcatus pseudofurcatus and the two other subspecies S. pseudofurcatus obliquus (Wall, 1967) Lentin \& Williams, 1973 and S. pseudofurcatus granulatus Schiøler, 1994 in having a coarsely verrucate to vermiculate surface ornament instead of being smooth-walled or granulate.

Genus Thalassiphora Eisenack \& Gocht, 1960 emend. Benedek \& Gocht, 1981

Thalassiphora rota $\mathrm{sp}$. nov.

(Pl. 5, figs 1-4; Fig. 7)

1986b Thalassiphora? sp. A Powell: 121, pl. 5, fig. 4. 1986c Thalassiphora? sp. A Powell: 139, pl. 1, fig. 4.

1989 ?Invertocysta sp. 1 Manum et al.: 642, pl. 3, fig. 9.

1995 Dalella siciliense Zevenboom \& Santarelli (in Zevenboom): 169, pl. III, figs 1-6.

Type species. Thalassiphora pelagica (Eisenack, 1954) Eisenack \& Gocht, 1960 emend. Benedek \& Gocht, 1981.

Derivation of name. Latin: rota, $-a e$, wheel. With reference to the general shape of the species.

Diagnosis. Chorate gonyaulacoid cyst surrounded by a subcircular, ring-shaped membranous and perforated ectophragm connected to the cyst body by nine processes. Archaeopyle precingular (type $\mathrm{P}_{3}$ ').

Holotype. MGUH 26748, SM 452 (Pl. 5, fig. 1; Fig. 7a).

Paratypes. (1) MGUH 26749 (Pl. 5, fig. 2; Fig. 7b); (2) MGUH 26750, SM 509 (P1. 5, fig. 4).

Horizon. Lark Formation, 5270-5300' (1615.4-1606.3 m). Lowermost Burdigalian.

Description. Large gonyaulacoid autocyst, composed of a subcircular to oval central body and a ring-shaped membranous 
ectophragm. The central body is thin-walled and smooth, lacking indication of paratabulation apart from the angular precingular archaeopyle. The ectophragm is separated from the central body by nine, usually straight to slightly curved processes which are oval in cross-section at their proximal point of attachment, but elsewhere are flat with a thickened central ridge. The processes appear almost evenly distributed on the dorsal surface of the central body close to its ambitus, giving the cyst a wheel-like appearance. It is not possible to determine the exact location of the processes, as the paratabulation of the species cannot be determined, except for the archaeopyle. The processes are probably attached on precingular, cingular and postcingular paraplates, as well as apically and antapically. For ease of recognition, the nine processes have been numbered 1-9 in a counterclockwise manner on the cyst positioned with its dorsal side up, with 1 being the process located directly above the archaeopyle (Fig. 7). When numbered in this way, processes 5 and 6 can be found in antapical position, 4 and 7 occupying postcingular positions, 8 and 3 cingular positions and 2 and 9 in precingular positions (Fig. 7). Distally, the processes are connected by a thin-walled ectophragm that curls over to the ventral side of the cyst. Ventrally, the ectophragm has a very large sub-circular opening that extends almost to the perimeter. The ectophragm usually has two large perforations in apical and antapical position, located above processes 1, 2 and 9 and 4-7 (Pl. 5, figs 1-3; Fig. 7). These two perforations are located on the dorsal side of the cyst and create a ribbon-like connection between the adjacent processes (between processes 1, 9 and 4, 5 in Fig. 7a; between 1, 2, 9 and 5, 6, 7 in Fig. 7b). Additional perforations may occur between the two large perforations (Fig. 7b). The archaeopyle is precingular, type $\mathrm{P}_{3^{\prime \prime}}$, from its shape and position. The paracingulum is indicated on some specimens by low ridges on the periphragm (Fig. 7a above process 8; Pl. 5, fig. 1). Apart from the archaeopyle and rare indications of paracingulum, the paratabulation is not indicated on the cyst.

Dimensions. Fifteen specimens were measured $(\mu \mathrm{m})$.

$\begin{array}{lll} & \text { Holotype } & \text { Range } \\ \text { Length, cyst body } & 48 & 39(44) 50 \\ \text { Width, cyst body } & 45 & 30(37) 47 \\ \text { Overall diameter (mean) } & 112 & 80(100) 121\end{array}$

Stratigraphical range. Uppermost Aquitanian to lowermost Burdigalian in Alma-1X.

Remarks. Manum et al. (1989, pl. 3, fig. 9) figured a specimen of a dinoflagellate cyst similar to Thalassiphora rota from ODP Site 643 in the Norwegian Sea as ?Invertocysta sp. 1. This taxon has nine processes connecting the cyst body with the ectophragm. The two taxa are considered conspecific. The taxon recorded by
Manum and collaborators is restricted to the Early Miocene Evitosphaerula paratabulata Zone of Manum et al. (1989) and thus occurs in the same interval as $T$. rota. Zevenboom \& Santarelli in Zevenboom (1995) figured two specimens of the manuscript species 'Dalella siciliense' from strata of Serravallian-Tortonian (Mid-Late Miocene) age in Sicily, South Italy. The taxon is similar to $T$. rota and the two taxa are probably conspecific. However, the stratigraphical occurrence interval for the Sicilian specimens is clearly above that of the specimens reported from the North Sea and the Greenland Sea. Powell (1986b, pl. 5, fig. 4; 1986c, pl. 1, fig. 4) figured specimens similar to $T$. rota as Thalassiphora? sp. A from the Aquitanian and Tortonian stages of the Piedmont Basin, north Italy. The specimens are considered conspecific with $T$. rota. Head et al. (1989a, pl. 4, figs 1, 2, 4; pl. 6, figs 1-3, 6, 7) figured specimens similar to the new species (as Gen. et sp. indet. 1) from the Upper Miocene of ODP Leg 105, Labrador Sea. However, these differ in having fewer connecting processes than the new species and in being much smaller; only two-thirds of the size of $T$. rota. Specimens of Thalassiphora cf. delicata, an undescribed taxon from the Paleocene of the North Sea illustrated by Powell (1992, pl. 4.4, fig. 5), are similar to $T$. rota in being wheel-shaped and in having perforations in the periphragm. The new taxon differs from $T$. cf. delicata in having larger perforations and thinner processes.

\section{ACKNOWLEDGEMENTS}

Yvonne Desezar is thanked for preparing the samples, and Stefan Sølberg is thanked for help with preparing the textfigures. Jan Andsbjerg provided the seismic data in Figure 3. Data from unpublished company reports from Robertson Research International Limited and RPS Consultants Limited have been consulted during the course of this study in order to validate the FDO succession suggested herein. The micropalaeontologists and palynologists behind these reports are acknowledged for their thorough biostratigraphic work on the North Sea Basin. Martin Head (University of Cambridge, UK) and Dirk Munsterman (Netherlands Institute for Applied Geoscience NITG, Utrecht) are thanked for sharing their insight on Palaeogene-Neogene dinoflagellates. The author is grateful to Rex Harland (DinoData Services, Nottingham, UK) and Henk Brinkhuis (University of Utrecht, The Netherlands), for constructive criticism on the initial manuscript. Suggestions from the referee, James Powell, and the Editor, F. John Gregory, improved the manuscript considerably. The Direction of GEUS is thanked for funding colour reproduction of Plates 1-19. This paper is a contribution to project 1313/00-0004 Palaeogene Stratigraphy, supported by the Danish Energy Authority.

\section{Manuscript received 16 February 2004 Manuscript accepted 15 December 2004}

Explanation of Plate 1.

Dinoflagellates from the Miocene of Alma-1X. Figures are to the same scale; scale bar in figure 1 is $20 \mu \mathrm{m}$. DS, dorsal surface; VS, ventral surface; RS, right lateral surface; LS, left lateral surface; HF, high focus; LF, low focus; SF, sectional focus: 1, Apteodinium spiridoides, LVR 24174, SM 438, SF, DS up; 2, Exochosphaeridium insigne, LVR 24296, SM 463, SF; 3, Pentadinium laticinctum laticinctum, LVR 23147, DS in HF; 4, Pentadinium imaginatum, LVR 24234, SF; 5, Apteodinium australiense, LVR 24197, SM 453, 
North Sea Oligocene-Lower Miocene dinoflagellates and acritarchs

SF, RS up; 6, Hystrichosphaeropsis obscura, LVR 24171, SM 439, DS in HF; 7, Spiniferites pseudofurcatus pseudofurcatus, LVR 24105, DS in HF; 8, Palaeocystodinium powellense, LVR 24172, SM 437, DS in HF; 9, Palaeocystodinium miocaenicum, LVR 24190, SF; 10, Cannosphaeropsis passio, LVR 24168, SM 441, SF, DS up; 11, Coustaudinium aubryae, LVR 24170, SM 442, SF; 12, Hystrichostrogylon membraniphorum, LVR 24232, SF, LS up; 13, Achomosphaera ramulifera ramulifera, LVR 24424, SF, DS up; 14, Spiniferites crassivariabilis, LVR 24231, SM 443, SF; 15, Glaphyrocysta texta, LVR 24297, SM 471, SF.

Explanation of Plate 2.

Dinoflagellates from the Miocene of Alma-1X. Figures are to the same scale; scale bar in figure 1 is $20 \mu \mathrm{m}$. Abbreviations as in Plate 1: 1, Lingulodinium machaerophorum, LVR 24237, DS in HF; 2, Heterosphaeridium heteracanthum, LVR 20450, DS in HF; 3, Batiacasphaera micropapillata, LVR 24423, SF, VS up; 4, Heteraulacacysta campanula, LVR 21442, SF; 5, Heteraulacacysta campanula, LVR 24209, antapical view, HF; 6, Hystrichokolpoma rigaudiae, LVR 24267, SF; 7, Operculodinium piaseckii, LVR 20694, SF, RS up; 8, Operculodinium sp. 3 of de Verteuil \& Norris, 1996b, LVR 24065, SF, RS up; 9, Pyxidinopsis fairhavenensis, LVR 22005, DS in HF; 10, Pyxidinopsis fairhavenensis, LVR 22006, SF; 11, Melitasphaeridium choanophorum choanophorum, LVR 20504, RS in HF; 12, Melitasphaeridium choanophorum reductum, LVR 24251, SM 457, RS in HF; 13, Reticulatosphaera actinocoronata, LVR 24402, SF; 14, Reticulatosphaera actinocoronata, LVR 24206, SF, specimen with process tips connected by trabeculae.

Explanation of Plate 3.

Dinoflagellates from the Miocene of Alma-1X. Figures are to the same scale; scale bar in figure 1 is $20 \mu \mathrm{m}$. Abbreviations as in Plate 1: 1, Distatodinium paradoxum, LVR 24244, SF; 2, 'Distatodinium cavatum' of Zevenboom \& Santarelli in Zevenboom (1995, manuscript name), LVR 24243, SF; 3, Operculodinium centrocarpum, LVR 26033, SM 449, SF, VS up; 4, 'Operculodinium variabile' of Zevenboom \& Santarelli in Zevenboom, (1995, manuscript name), LVR 24285, LS in HF; 5, Pyxidinopsis eliptica, LVR 20464, DS in HF; 6, Habibacysta tectata, LVR 20384, SF; 7, Cordosphaeridium minimum, LVR 24702, SF; 8, Impletosphaeridium insolitum, LVR 24430, SF; 9, Spiniferites solidago, LVR 24305, SM 473, SF; 10, Cleistosphaeridium ancyrea, LVR 24175, SM 438, SF, VS up; 11, Spiniferites spongiophragmatus, LVR 21152, SF; 12, Nematosphaeropsis labyrinthus, LVR 22236, SF; 13, Tuberculodinium vancampoae, LVR 21423, SF, oblique antapical view; 14, Tuberculodinium vancampoae, same specimen as fig. 13, HF on antapical archaeopyle.

\section{Explanation of Plate 4.}

Dinoflagellates from the Miocene of Alma-1X. Figures are to the same scale; scale bar in figure 1 is $20 \mu \mathrm{m}$. Abbreviations as in Plate 1: 1, Lejeunecysta cinctoria, LVR 21308, SF, apical view; 2, Lejeunecysta cinctoria, LVR 21309, SF; 3, Selenopemphix sp., LVR 24920, SF; 4, Selenopemphix sp., LVR 23747, SF, DS up; 5, Selenopemphix sp., LVR 23754, SF, apical view; 6, Lejeunecysta sp., LVR 21369, SF; 7, Lejeunecysta sp., LVR 23793, SF, DS up; 8, Cyclopsiella granulata, LVR 24768, SF; 9, Cymatiosphaera sp. 1, LVR 21156, SF; 10, Cymatiosphaera sp. 1, LVR 21157, SF; 11, Brigantedinium? sp., LVR 24224, SF; 12, Brigantedinium? sp., LVR 24215, SF; 13, Artemisiocysta cladodichotoma, LVR 24403, SF; 14, Artemisiocysta cladodichotoma, LVR 23787, SF; 15, Ectosphaeropsis burdigalensis, LVR 21773, SF, DS up; 16, Polysphaeridium zoharyi, LVR 20535, antapical view, HF.

\section{Explanation of Plate 5.}

Dinoflagellates from the Oligocene and Miocene of Alma-1X. Figures are to the same scale; scale bar in figure 1 is $20 \mu \mathrm{m}$. Abbreviations as in Plate 1: 1, Thalassiphora rota sp. nov., holotype, LVR 24193, SM 452, SF, DS up; 2, Thalassiphora rota sp. nov., paratype, LVR 24222, SF, VS up; 3, Thalassiphora rota sp. nov., LVR 24223, SF, DS up; 4, Thalassiphora rota sp. nov., paratype, LVR 26079, SM 509, SF, VS up; 5, Tityrosphaeridium cantharellus, LVR 21461, VS in HF; 6, 'Hystrichokolpoma reducta' of Zevenboom \& Santarelli in Zevenboom (1995, manuscript name), LVR 24200, SM 450, SF; 7, Palaeocystodinium golzowense, LVR 24724-5 (composite image), SF; 8, Fibrocysta sp. 1, LVR 24311, SM 468, SF, LS up; 9, Lejeunecysta tenella, LVR 24678, SF, DS up; 10, Chiropteridium galea, LVR 23789, DS in HF; 11, Deflandrea phosphoritica, LVR 24247, DS in HF; 12, Hystrichokolpoma cinctum, LVR 24767, SF; 13, Sumatradinium cf. druggii, LVR 24376, SF; 14, Thalassiphora pelagica, LVR 24723, SF, DS up.

Explanation of Plate 6.

Dinoflagellates from the Oligocene and Miocene of Alma-1X. Figures are to the same scale except 19 and 20; scale bar in figure 1 is $20 \mu \mathrm{m}$; scale bar in figure 19 is $10 \mu \mathrm{m}$. Abbreviations as in Plate 1: 1, Bitectatodinium? sp. 1 of Manum et al. (1989), LVR 21191, DS in HF; 2, Caligodinium amiculum, LVR 24726, SF, hypocystal archaeopyle down; 3, Achomosphaera sp. 1, LVR 24214, SF, LS up; 4, Leptodinium cf. italicum, LVR 24217, SF, RS up; 5, Leptodinium italicum, LVR 24289, SF, RS up; 6, Leptodinium italicum, LVR 24286, VS in HF; 7, Cyclopsiella sp. 1, LVR 23764, SF; 8, Tectatodinium sp. 1 of Châteauneuf (1980), LVR 21821, SF, RS up; 9, Filisphaera microornata, LVR 24263, SF; 10, Gelatia inflata, LVR 23805, SF; 11, Tectatodinium pellitum, LVR 24565, SF, DS up; 12, Batiacasphaera hirsuta, LVR 23794, SF; 13, Nematosphaeropsis lemniscata, LVR 24066, SF; 14, Operculodinium sp. 11, LVR 22161, SF; 15, Leberidocysta? sp. 1, LVR 21158, SF; 16, Filisphaera pachyderma sp. nov., paratype, LVR 24255, SM 319, DS in HF; 17, Filisphaera pachyderma sp. nov., holotype, LVR 24253, SM 320, DS in HF; 18, Filisphaera pachyderma sp. nov., holotype, SF, DS up; 19, Filisphaera pachyderma sp. nov., holotype, close-up of DS (HF); 20, Filisphaera pachyderma sp. nov., holotype, close-up of luxuriae (SF); 21, Filisphaera pachyderma sp. nov., paratype, LVR 23290, SM 302, SF, VS up. 
Explanation of Plate 7.

Dinoflagellates from the Miocene and Oligocene of Alma-1X. Figures are to the same scale; scale bar in figure 1 is $20 \mu \mathrm{m}$. Abbreviations as in Plate 1: 1, Chiropteridium lobospinosum, LVR 24260, VS in HF; 2, Saturnodinium sp. 1, LVR 24676, oblique apical view, SF; 3, Saturnodinium sp. 1, LVR 24675, SF, LS up; 4, Membranophoridium aspinatum, LVR 21519, SF, DS up; 5, Polysphaeridium subtile, LVR 24284, HF; 6, Chiropteridium sp. 1, LVR 24241, SF; 7, Trinovantedinium cf. applanatum, LVR 22128, SF; 8, Impagidinium velorum, LVR 24730, SF; 9, Homotryblium pallidum, LVR 21270, LF, oblique axial view; 10, Homotryblium cf. oceanicum, LVR 20679, HF; 11, Homotryblium plectilum, LVR 21307, LF; 12, Batiacasphaera? sp. 1, LVR 22797, SF, RS up; 13, Homotryblium floripes, LVR 21310, LF on antapical surface; 14, Lejeunecysta fallax, LVR 24258, SF, DS up.

\section{Explanation of Plate 8.}

Dinoflagellates from the Oligocene and Miocene of Alma-1X. Figures 1-10 are to the same scale; figures 11-13 and 16-18 are to the same scale; figures 14-15 are to the same scale; scale bars in figures 1 and 11 are $20 \mu \mathrm{m}$; scale bar in figure 14 is $10 \mu \mathrm{m}$. Abbreviations as in Plate 1: 1, Distatodinium biffi, LVR 21471, SF; 2, Spiniferites ramosus ssp. 3, LVR 24293, SF, DS up; 3, Pentadinium laticinctum granulatum, LVR 24298, SM 461, SF, LS up; 4, Glaphyrocysta? vicina, LVR 25967, SM 469, VS in HF; 5, Crassosphaera sp. 1, LVR 24581, SM 480, SF; 6, Crassosphaera sp. 1, same specimen as fig. 5, HF; 7, Crassosphaera concinna, LVR 25984, SF; 8, Crassosphaera concinna, same specimen as fig. 7, HF; 9, Hystrichokolpoma salacia, LVR 24301, SM 472, SF; 10, Hystrichokolpoma salacia, same specimen as fig. 9, HF; 11, Pentadinium corium sp. nov., paratype, LVR 21478, antapex in HF; 12, Pentadinium corium sp. nov., paratype, LVR 24429, SM 458, DS in LF, oblique antapical view; 13, Filisphaera filifera, LVR 24275, SF; 14, Filisphaera filifera, same specimen as fig. 13, HF on surface ornament; 15, Filisphaera filifera, same specimen as fig. 13, SF on surface ornament; 16, Pentadinium corium sp. nov., LVR 26083, SM 511, DS in HF; 17, Pentadinium corium sp. nov., holotype, LVR 26082, SM 510, SF, LS up; 18, Pentadinium corium sp. nov., same specimen as fig. 17, HF.

\section{Explanation of Plate 9.}

Dinoflagellates from the Oligocene of Alma-1X. Figures are to the same scale; scale bar in figure 1 is $20 \mu \mathrm{m}$. Abbreviations as in Plate 1: 1, Cleistosphaeridium diversispinosum, LVR 24271, SF, DS up; 2, Cleistosphaeridium diversispinosum, LVR 24283, SF, VS up; 3, Hystrichokolpoma? sp. 1, LVR 24268, SF, DS up; 4, Cleistosphaeridium? sp. 1, LVR 21412, VS in HF; 5, Cleistosphaeridium? sp. 1, same specimen as fig. 4, SF; 6, Cleistosphaeridium placacantha, LVR 24282, SF; 7, Operculodinium sp. 7, LVR 21356, DS in HF; 8, Operculodinium sp. 7, same specimen as fig. 7, VS in LF; 9, Fromea sp. 1, LVR 24292, SF; 10, Fromea sp. 1, LVR 24290, oblique antapical view, LF on pylome margin; 11, Fromea sp. 1, same specimen as fig. 10, HF on antapex; 12, Fromea chytra, LVR 21465, SF; 13, dinocyst VI of Manum (1976), LVR 21365, SF; 14, dinocyst VI of Manum (1976), LVR 25355, SF; 15, Impagidinium aculeatum, LVR 22008, SF, DS up; 16, Dapsilidinium pseudocolligerum, LVR 24308, SF; 17, Pentadinium? sp. 1, LVR 24306, SM 465, SF, RS up.

\section{Explanation of Plate 10.}

Dinoflagellates from the Oligocene of Alma-1X. Figures 1-11, 15 are to the same scale; figures 12, 14, 16 are to the same scale; scale bars in figures 1 and 12 are $20 \mu \mathrm{m}$; scale bar in figure 13 is $10 \mu \mathrm{m}$. Abbreviations as in Plate 1: 1, Palaeocystodinium sp. 1 of Manum et al. (1989), LVR 24674, SF, DS up; 2, Palaeocystodinium sp. 1 of Manum et al. (1989), LVR 24378, SF; 3, Svalbardella cf. cooksoniae, LVR 24401, SF; 4, Svalbardella cooksoniae, LVR 24397, SF; 5, Svalbardella cooksoniae, LVR 21522, SF; 6, Palaeocystodinium sp. 2 of Damassa et al. (1990), LVR 24399, SF; 7, Palaeocystodinium sp. 2 of Damassa et al. (1990), LVR 24398, SF; 8, Wetzeliella symmetrica, LVR 23801, SF, DS up; 9, Pleurozonaria globula, LVR 25070, SM 489, HF; 10, Wetzeliella gochtii, LVR 24672, SF, VS up; 11, Hystrichokolpoma pusillum, LVR 26019, HF, oblique apical view; 12, Selenopemphix? sp. 2 of Head et al. (1989b), LVR 24405, SF; 13, Selenopemphix? sp. 2 of Head et al. (1989b), same specimen as figure 12, close-up of gemmate cingulum, LVR 26047; 14, Hystrichokolpoma sp. 3, LVR 21526, HF; 15, Spiniferites sp. 2 of Manum et al. (1989), LVR 25719, SM 499, SF; 16, Thalassiphora cf. patula, LVR 24315, SF.

\section{Explanation of Plate 11.}

Dinoflagellates from the Oligocene of Alma-1X. Figures 1-3, 5-13 are to the same scale; figures 4, 14 are to the same scale; scale bar in figure 1 is $20 \mu \mathrm{m}$; scale bar in figure 4 is $10 \mu \mathrm{m}$. Abbreviations as in Plate 1: 1, Cerebrocysta? namocensis, LVR 24410, SF, LS up; 2, Cerebrocysta? namocensis, LVR 24412, SF, LS up; 3, Cerebrocysta? namocensis, LVR 24408, SF, LS up; 4, Cerebrocysta? namocensis, same specimen as fig. 3, surface ornament in HF; 5, Areoligera semicirculata, LVR 21480, SF, VS up; 6, Dapsilidinium simplex, LVR 24561, SF; 7, Gerlachidium aechmophorum, LVR 24579, SF, DS up; 8, Areoligera semicirculata, LVR 21534, DS in HF; 9, Hystrichostrogylon sp. 1 of Manum et al. (1989), LVR 24380, SF; 10, Deflandrea heterophlycta, LVR 24145, SF, DS up; 11, Dinopterygium cladoides sensu Morgenroth (1966), LVR 24707, SF; 12, Dinopterygium cladoides sensu Morgenroth (1966), LVR 24421, HF, apical view; 13, Saturnodinium pansum, LVR 24415, SF, apical view; 14, Saturnodinium pansum, same specimen as fig. 13 , close-up of lateral spines.

Explanation of Plate 12.

Dinoflagellates from the Oligocene of Alma-1X. Figures are to the same scale; scale bar in figure 1 is $20 \mu \mathrm{m}$. Abbreviations as in Plate 1: 1, Spiniferella cf. cornuta, LVR 24582, SM 477, LS in HF; 2, Spiniferella cf. cornuta, LVR 24669, RS in HF; 3, 
North Sea Oligocene-Lower Miocene dinoflagellates and acritarchs

Achilleodinium sp. 1 of Heilmann-Clausen \& Costa (1989), LVR 21532, SF; 4, Operculodinium floridium, LVR 21458, HF; 5, Operculodinium floridium, same specimen as fig. 4, SF; 6, Cerebrocysta sp. 1, LVR 23790, SF; 7, Araneosphaera stephanophora, LVR 25348, SF; 8, Achomosphaera sp. 4, LVR 24566, SF; 9, Achomosphaera sp. 4, LVR 24677, SF; 10, Cordosphaeridium fibrospinosum, LVR 24788, HF, apical view; 11, Amphorosphaeridium? almae sp. nov., holotype, LVR 24682, SF, VS up; 12, Amphorosphaeridium? almae sp. nov., paratype, LVR 21512, SF, LS up; 13, Amphorosphaeridium? almae sp. nov., paratype, LVR 24683, SF, antapical view.

\section{Explanation of Plate 13.}

Dinoflagellates from the Oligocene of Alma-1X. Figures 1-6 are to the same scale; figures 7-15 are to the same scale; scale bars in figures 1 and 7 are $20 \mu \mathrm{m}$. Abbreviations as in Plate 1: 1, Rhombodinium draco, LVR 24691, SF, VS up; 2, Charlesdowniea chlatrata, LVR 24785, SF, DS up; 3, Thalassiphora patula, LVR 24571, SM 476, SF, RS up; 4, Operculodinium xanthium, LVR 26049, SF, LS up; 5, Lejeunecysta hyalina, LVR 25797, SM 502, SF, DS up; 6, Distatodinium elipticum, LVR 21490, SF; 7, Phthanoperidinium amoenum, LVR 24686, SF, DS up; 8, Phthanoperidinium amoenum, LVR 26048, SF, DS up; 9, Phthanoperidinium geminatum, LVR 24766, LS in HF; 10, Phthanoperidinium multispinum, LVR 24772, SF; 11, Microdinium cf. reticulatum, LVR 24900, SF; 12, Hystrichosphaeropsis rectangularis, LVR 24763, SF, LS up; 13, Enneadocysta pectiniformis, LVR 26010, SF, DS up; 14, Enneadocysta pectiniformis, LVR 21760, VS in HF; 15, Cribroperidinium guiseppei, LVR 25349, DS in HF.

\section{Explanation of Plate 14.}

Dinoflagellates from the Oligocene of Alma-1X. Figures are to the same scale; scale bar in figure 1 is $20 \mu \mathrm{m}$. Abbreviations as in Plate 1: 1, Distatodinium tenerum, LVR 24839, SF; 2, Homotryblium tenuispinosum, LVR 24923, SF; 3, Deflandrea sp. 1, LVR 22034, SF; 4, acritarch sp. 2 of Head et al. (1989b), LVR 24843, SF; 5, acritarch sp. 2 of Head et al. (1989b), LVR 24842, SF; 6, Melitasphaeridium pseudorecurvatum, LVR 21046, SF; 7, Impletosphaeridium kroemmelbeinii, LVR 24881, SF; 8, Spiniferella cornuta cornuta, LVR 21554, DS in HF, operculum in place; 9, Pentadinium lophophorum, LVR 25798, SM 503, SF, oblique antapical view; 10, Deflandrea granulata, LVR 21547, SF, VS up; 11, Achomosphaera sagena, LVR 24789, HF; 12, Pentadinium? circumsutum, LVR 24790, SF; 13, Impagidinium cf. japonicum, LVR 24905, SF; 14, Impagidinium cf. japonicum LVR 24879, VS in HF.

\section{Explanation of Plate 15.}

Dinoflagellates from the Oligocene of Alma-1X. Figures are to the same scale; scale bar in figure 1 is $20 \mu \mathrm{m}$. Abbreviations as in Plate 1: 1, Achilleodinium biformoides, LVR 21966, SF, RS up; 2, Elytrocysta brevis, LVR 24876, HF; 3, Elytrocysta brevis, LVR 24901, HF; 4, Caligodinium cf. pychnum, LVR 24841, HF, hypocystal archaeopyle down; 5, Caligodinium cf. pychnum, LVR 24840, SF, hypocystal archaeopyle down; 6, Corrudinium incompositum, LVR 24106, LS in HF; 7, Corrudinium incompositum, LVR 24109, SF, LS up; 8, Corrudinium incompositum, LVR 26013, DS in HF; 9, Corrudinium cristatum, LVR 21995, RS in HF; 10, Corrudinium cristatum, same specimen as fig. 9, LS in LF; 11, Deflandrea leptodermata, LVR 24884, VS in HF; 12, Deflandrea leptodermata, LVR 24882, DS in LF; 13, Samlandia chlamydophora, LVR 22066, SF, VS up; 14, Spiniferites ramosus ssp. 4, LVR 24831, SF; 15, Spiniferites ramosus ssp. 4, same specimen as fig. 14, HF; 16, Lentinia serrata, LVR 24927, SF, DS up; 17, Operculodinium cf. floridium of Torricelli \& Biffi (2001), LVR 24874, LS in HF.

\section{Explanation of Plate 16.}

Dinoflagellates from the Oligocene of Alma-1X. All figures are to the same scale except figure 3; scale bar in figure 1 is $20 \mu \mathrm{m}$; scale bar in figure 3 is $10 \mu \mathrm{m}$. Abbreviations as in Plate 1: 1, Spiniferites manumii comb. nov., LVR 25065, SM 486, SF, LS up; 2, Spiniferites manumii comb. nov., same specimen as fig. 1, HF; 3, Spiniferites manumii comb. nov., LVR 24886, close-up of surface ornament; 4, Spiniferites manumii comb. nov., LVR 24999, SM 481, DS in HF; 5, Spiniferites manumii comb. nov., LVR 25003, SM 485, VS in HF; 6, Spiniferites manumii comb. nov., LVR 25005, SM 484, DS in LF; 7, Achomosphaera alcicornu, LVR 22988, SF, LS up; 8, Cordosphaeridium gracile, LVR 21814, SF, RS up; 9, Cordosphaeridium gracile, LVR 21815, SF, VS up, apex pointing to 10 o'clock; 10, Fibrocysta axialis, LVR 24875, SF, LS up; 11, Achomosphaera alcicornu, LVR 24907, SF, DS up.

\section{Explanation of Plate 17.}

Dinoflagellates from the Eocene and Oligocene of Alma-1X. Figures are to the same scale; scale bar in figure 1 is $20 \mu \mathrm{m}$. Abbreviations as in Plate 1: 1, Thalassiphora succincta, LVR 25362, LS in HF; 2, Thalassiphora succincta, LVR 26023, SF, DS up; 3, Glaphyrocysta semitecta, LVR 25647, DS in LF; 4, Impletosphaeridium sp. 1., LVR 25345, SF; 5, Impletosphaeridium sp. 1, same specimen as fig. 4, HF; 6, Impagidinium dispertitum, LVR 25350, DS in HF; 7, Impagidinium dispertitum, same specimen as fig. 6, VS in LF; 8, Adnatosphaeridium robustum, LVR 22099, SF; 9, Adnatosphaeridium robustum, LVR 23135, SF; 10, Impagidinium maculatum, LVR 24915, SF, RS up; 11, Phthanoperidinium comatum, LVR 24909, SF; 12, Phthanoperidinium comatum, LVR 24091, SF; 13, Phthanoperidinium comatum, LVR 25342, SF; 14, Microdinium sp. 1 of Châteauneuf (1980), LVR 24899, RS in HF; 15, Microdinium sp. 1 of Châteauneuf (1980), LVR 24129, VS in HF; 16, Melitasphaeridium asterium, LVR 24908, SF.

\section{Explanation of Plate 18.}

Dinoflagellates from the Eocene and Oligocene of Alma-1X. Figures 1, 2, 10-13 are to the same scale; figures 3-9 are to the same scale; scale bars in figures 1 and 3 is $20 \mu \mathrm{m}$. Abbreviations as in Plate 1: 1, Areosphaeridium diktyoplokum, LVR 25335, SM 495, SF, 
VS up; 2, Areosphaeridium diktyoplokum, LVR 25334, SM 494, SF, DS up; 3, Spiniferites ramosus ssp. 5, LVR 25363, SF; 4, Areosphaeridium michoudii, LVR 25920, SM 506, SF, VS up; 5, Batiacasphaera compta, LVR 21749, apical view, archaeopyle margin in HF; 6, Batiacasphaera compta, LVR 21710, HF; 7, Areosphaeridium michoudii, LVR 25923, SM 508, SF, DS up; 8, Hystrichokolpoma sp. 5, LVR 24080, HF; 9, Hystrichokolpoma sp. 5, same specimen as fig. 8, SF; 10, Operculodinium divergens, LVR 25918, SM 505, SF, RS up; 11, Operculodinium divergens, LVR 25921, SM 507, RS in HF; 12, Operculodinium divergens, LVR 24922, RS in HF; 13, Thalassiphora fenestrata, LVR 25340, SM 500, LS in HF.

\section{Explanation of Plate 19.}

Dinoflagellates from the Eocene of Alma-1X. Figures 1-3, 5-6, 12-16 are to the same scale; figures 8-11 are to the same scale; figures 4 and 7 are to the same scale; scale bars in figures 1 and 8 are $20 \mu \mathrm{m}$; scale bar in figure 4 is $10 \mu \mathrm{m}$. Abbreviations as in Plate 1 : 1, Spiniferites pseudofurcatus verrucosus ssp. nov. paratype, LVR 26016, DS in HF, apex pointing to 2 o'clock; 2, Spiniferites pseudofurcatus verrucosus ssp. nov., holotype, LVR 25341, SM 501, HF, antapical view; 3, Spiniferites pseudofurcatus verrucosus ssp. nov., paratype, LVR 24111, DS in HF; 4, Spiniferites pseudofurcatus verrucosus ssp. nov., LVR 26050, close-up on surface ornament of antapical paraplate; 5, Thalassiphora reticulata, LVR 26027, SF; 6, Rhombodinium porosum, LVR 26021, SF, VS up; 7, Rhombodinium porosum, same specimen as fig. 6, close-up of perforated periphragm; 8, Heteraulacacysta porosa, LVR 21819, SF; 9, Heteraulacacysta porosa, LVR 26014, SF, axial view; 10, Cerebrocysta bartonensis, LVR 21719, HF; 11, Cerebrocysta bartonensis, LVR 21717, DS in HF; 12, Operculodinium tiara, LVR 21744, VS in HF; 13, Operculodinium tiara, LVR 21817, DS in HF; 14, Operculodinium tiara, LVR 21818, SF; 15, Operculodinium tiara, LVR 22075, RS in HF; 16, Operculodinium tiara, LVR 21816, SF, LS up.

\section{REFERENCES}

Batten, D.J. 1999. Small palynomorphs. In: Jones, T.P. \& Rowe, N.P. (Eds), Fossil plants and spores: modern techniques. Geological Society, London, 15-19.

Benedek, P.N. 1972. Phytoplanktonten aus dem Mittel- und Oberoligozän von Tönisberg (Niederrheingebiet). Palaeontographica, Abt. B, 137: 1-71.

Berggren, W.A., Kent, D.V. \& Flynn, J.J. 1985a. Jurassic to Paleogene: Part 2 Paleogene geochronology and chronostratigraphy. In: Snelling, N.J. (Ed.), The Chronology of the Geological Record. Geological Society, London, Memoir, 10: 141-195.

Berggren, W.A., Kent, D.V. \& van Couvering, J.A. 1985b. The Neogene: Part 2 Neogene geochronology and chronostratigraphy. In: Snelling, N.J. (Ed.), The Chronology of the Geological Record. Geological Society, London, Memoir, 10: 211-260.

Berggren, W.A., Kent, D.V., Swisher, C.C. \& Aubry, M.-P. 1995. A revised Cenozoic geochronology and chronostratigraphy. In: Berggren, W.A., Kent, D.V., Aubry, M.-P. \& Hardenbol, J. (Eds), Geochronology, Time Scale and and Global Stratigraphic Correlation. SEPM Special Publication, 54: 129-212.

Brinkhuis, H. 1994. Late Eocene to Early Oligocene dinoflagellate cysts from the Priabonian type-area (Northeast Italy): biostratigraphy and paleoenvironmental interpretation. Palaeogeography, Palaeoclimatology, Palaeoecology, 107: 121-163.

Brinkhuis, H. \& Biffi, U. 1993. Dinoflagellate cyst stratigraphy of the Eocene/Oligocene transition in central Italy. Marine Micropaleontology, 22: 131-183.

Brinkhuis, H. \& Visscher, H. 1995. The upper boundary of the Eocene Series: a reappraisal based on dinoflagellate cyst biostratigraphy and sequence stratigraphy. In: Berggren, W.A., Kent, D.V., Aubry, M.-P. \& Hardenbol, J. (Eds), Geochronology, Time Scale and Global Stratigraphic Correlation. SEPM Special Publication, 54: 295-304.

Brinkhuis, H., Powell, A.J. \& Zevenboom, D. 1992. High-resolution dinoflagellate cyst stratigraphy of the Oligocene/Miocene transition interval in northwest and central Italy. In: Head, M.J. \& Wrenn, J.H (Eds), Neogene and Quaternary Dinoflagellate Cysts and Acritarchs. American Association of Stratigraphic Palynologists Foundation, Dallas, 219-258.

Châteauneuf, J.-J. 1980. Palynostratigraphie et paléoclimatologie de l'Eocène supérieur et de l'Oligocène du Bassin de Paris. Mémoires du bureau de recherches géologiques et minières (BRGM), 116: 1-360.

Costa, L.I. \& Manum, S.B. 1988. The description of the interregional zonation of the Paleogene (D1-D15) and the Miocene (D16-D20). Geologisches Jahrbuch, Reihe A, 100: 321-330.
Damassa, S.P., Goodman, D.K., Kidson, E.J. \& Williams, G.L. 1990. Correlation of Paleogene dinoflagellate assemblages to standard nannofossil zonation in North Atlantic DSDP sites. Review of Palaeobotany and Palynology, 65: 331-339.

Davey, R.J. 1969. The evolution of certain Upper Cretaceous hystrichospheres from South Africa. Palaeontologia Africana, 12: 25-51.

De Coninck, J. 1986. Organic-walled phytoplankton from the Bartonian and Eo-Oligocene transitional deposits of the Woensdrecht borehole, southern Netherlands. Mededelingen Rijks Geologische Dienst, 40-2: $1-49$.

De Coninck, J. 1999. Organic-walled phytoplankton biostratigraphy of the Eocene-Oligocene transition in the Kallo borehole and the Rupelian stratotype area (northwestern Belgium). Bulletin de Société belge de Géologie, 105: 171-209.

De Coninck, J. 2001. Organic-walled microfossils in the Oligocene Grimmertingen and Neerrepen Sand Members from the Grimmertingen type locality. Geological Survey of Belgium, Professional Paper, 2001/2, 294: 1-57.

de Verteuil, L. \& Norris, G. 1996a. Part I, Dinoflagellate cyst zonation and allostratigraphy of the Chesapeake Group. Micropaleontology, 42(suppl.): 1-82.

de Verteuil, L. \& Norris, G. 1996b. Part II, Homology and structure in dinoflagellate cyst terminology. Micropaleontology, 42(suppl.): 83-172.

Dybkjær, H. \& Rasmussen, E.S. 2000. Palynological dating of the Oligocene-Miocene succession in the Lille Bælt area, Denmark. Bulletin of the Geological Society of Denmark, 47: 87-103.

Evitt, W.R. 1985. Sporopollenin dinoflagellate cysts, their morphology and interpretation. American Association of Stratigraphic Palynologists Foundation, Dallas.

Fensome, R.A., Williams, G.L., Barss, M.S., Freeman, J.M. \& Hill, J.M. 1990. Acritarchs and fossil prasinophytes: an index to genera, species and infraspecific taxa. American Association of Stratigraphic Palynologists Foundation, Contribution Series, 25: 1-771.

Fensome, R.A., Taylor, F.J.R., Norris, G., Sarjeant, W.A.S., Wharton, D.I. \& Williams, G.L. 1993. A classification of living and fossil dinoflagellates. Micropaleontology, Special Publication, 7: 1-351.

Gerlach, E. 1961. Mikrofossilien aus dem Oligozän und Miozän Nordwestdeutschlands, unter besonderer Berücksichtigung der Hystrichosphaeren und Dinoflagellaten. Neues Jahrbuch für Geologie und Paläontologie, Abhandlungen, 112: 143-228.

Gradstein, F.M. \& Bäckström, S. 1996. Cainozoic biostratigraphy and palaeobathymetry, northern North Sea and Haltenbanken. Norsk Geologisk Tidsskrift, 76: 3-32. 
Gradstein, F.M., Kristiansen, I.L., Loemo, L. \& Kaminski, M.A. 1992. Cenozoic foraminiferal and dinoflagellate cyst biostratigraphy of the central North Sea. Micropaleontology, 38: 101-137.

Gradstein, F.M., Kaminski, M.A., Berggren, W.A., Kristiansen, I.L. \& D'Ioro, M.A. 1994. Cenozoic biostratigraphy of the North Sea and Labrador shelf. Micropaleontology, 40(suppl.): 1-152.

Hardenbol, J., Thierry, J., Farley, M.B., Jacquin, T., de Graciansky, P.-C. \& Vail, P.R. 1998. Mesozoic and Cenozoic sequence chronostratigraphic chart. In: de Graciansky, P.-C., Hardenbol, J., Jacquin, T., Vail, P.R. \& Farley, M.B. (Eds), Mesozoic and Cenozoic sequence stratigraphy of European Basins. SEPM Special Publication, 60: 3-13.

Head, M.J. 1994. Morphology and paleoenvironmental significance of the Cenozoic dinoflagellate genera Tectatodinium and Habibacysta. Micropaleontology, 40: 289-321.

Head, M.J., Norris, G. \& Mudie, P.J. 1989a. Palynology and dinocyst stratigraphy of the Upper Miocene and lowermost Pliocene, ODP Leg 105, site 646, Labrador Sea. In: Srivastava, S.P., Arthur, M. \& Clement, B. (Eds), Proceedings of the Ocean Drilling Program, Scientific Results, 105: 423-451.

Head, M.J., Norris, G. \& Mudie, P.J. 1989b. Palynology and dinocyst stratigraphy of the Miocene in ODP Leg 105, Hole 645E, Baffin Bay. In: Srivastava, S.P., Arthur, M. \& Clement, B. (Eds), Proceedings of the Ocean Drilling Program, Scientific Results, 105: 467-514.

Heilmann-Clausen, C. \& Costa, L.I. 1989. Dinoflagellate zonation of the uppermost Paleocene? to Lower Miocene in the Wursterheide research well, NW Germany. Geologisches Jahrbuch, Reihe A, 111 431-521.

Jan du Chêne, R.E. \& Adediran, S.A. 1985. Late Paleocene to Early Eocene dinoflagellates from Nigeria. Cahiers de Micropaléontologie, Centre Nationale de la Recherche Scientifique, 1984-3: 1-38.

King, C. 1983. Cainozoic micropalaeontological biostratigraphy of the North Sea. Institute of Geological Sciences Report, 82/7: 1-40.

King, C. 1989. Cenozoic of the North Sea. In: Jenkins, D.G. \& Murray, J.W. (Eds), Stratigraphical atlas of fossil foraminifera. Ellis Horwood Ltd, Chichester, 418-489.

Knox, R.W.O'B. \& Holloway, S. 1992. I. Paleogene of the Central and Northern North Sea. In: Knox, R.W.O'B. \& Cordey, W.G. (Eds), Lithostratigraphic nomenclature of the UK North Sea. British Geological Survey, Nottingham, 1-133.

Köthe, A. 1990. Paleogene dinoflagellates from Northwest Germanybiostratigraphy and paleoenvironment. Geologisches Jahrbuch, Reihe A, 118: 1-111

Liengjarern, M., Costa, L. \& Downie, C. 1980. Dinoflagellate cysts from the Upper Eocene-Lower Oligocene of the Isle of Wight. Palaeontology, 23: 475-499.

Lund, J.J. 2002. A lower Oligocene Norwegian Sea dinoflagellate cyst found in the North Sea and in the Rupelian type area in Belgium. Northern European Cenozoic Stratigraphy; Proceedings 8th Biannual meeting RCNNS/RCNPS. Landesamt für Natur und Umvelt des Landes Schleswig-Holstein, Flintbek, 83-89.

Manum, S.B. 1976. Dinocysts in Tertiary Norwegian-Greenland Sea sediments (Deep Sea Drilling Project Leg 38), with observations on palynomorphs and palynodebris in relation to environment. In Talwani, M. \& Udintsev, G. (Eds), Initial Reports DSDP, 38. US Government Printing Office, Washington, 897-919.

Manum, S.B., Boulter, M.C., Gunnarsdottir, H., Rangnes, K. \& Scholze, A. 1989. Eocene to Miocene palynology of the Norwegian Sea (ODP Leg 104). In: Eldholm, O., Thiede, J. \& Taylor, E. (Eds), Proceedings of the Ocean Drilling Program, Scientific Results, 104: 611-662.

Michelsen, O., Thomsen, E., Danielsen, M., Heilmann-Clausen, C., Jordt, H. \& Laursen, G.V. 1998. Cenozoic sequence stratigraphy in the eastern North Sea. In: de Graciansky, P.-C. \& Vail, P.R. (Eds), Mesozoic and Cenozoic Sequence Stratigraphy of European Basins. SEPM Special Publication, 60: 91-118.

Morgenroth, P. 1966. Mikrofossilien und Konkretionen des nordwesteuropäischen Untereozäns. Palaeontographica, Abteilung B, 119: 1-53.

Mudge, D.C. \& Bujak, J.P. 1996. An integrated stratigraphy for the Paleocene and Eocene of the North Sea. In: Knox, R.W.O'B., Corfield, R.M. \& Dunay, R.E. (Eds), Correlation of the Early Paleogene in Northwest Europe. Geological Society, London, Special Publications, 101: 91-113.
Piasecki, S. 1980. Dinoflagellate cyst stratigraphy of the Miocene Hodde and Gram Formations, Denmark. Bulletin of the Geological Society, Denmark, 29: 53-76.

Powell, A.J. 1986a. Latest Palaeogene and earliest Neogene dinoflagellate cysts from the Lemme Section, Northwest Italy. In: Wrenn, J.H., Duffield, S.L. \& Stein, J.A. (Eds), Papers from the first symposium on Neogene Dinoflagellate Cyst Biostratigraphy. American Association of Stratigraphic Palynologists Foundation, Contribution Series, 17: 83-104.

Powell, A.J. 1986b. A dinoflagellate cyst biozonation for the Late Oligocene to Middle Miocene succession of the Langhe Region, Northwest Italy. In: Wrenn, J.H., Duffield, S.L. \& Stein, J.A. (Eds), Papers from the first symposium on Neogene Dinoflagellate Cyst Biostratigraphy. American Association of Stratigraphic Palynologists Foundation, Contribution Series, 17: 105-127.

Powell, A.J. 1986c. The stratigraphic distribution of late Miocene dinoflagellate cysts from the Castellanian Superstage stratotype, Northwest Italy. In: Wrenn, J.H., Duffield, S.L. \& Stein, J.A. (Eds), Papers from the first symposium on Neogene Dinoflagellate Cyst Biostratigraphy. American Association of Stratigraphic Palynologists Foundation, Contribution Series, 17: 129-149.

Powell, A.J. 1992. Dinoflagellate cysts of the Tertiary System. In: Powell, A.J. (Ed.), Stratigraphic Index of Dinoflagellate Cysts. Chapman \& Hall, London, 155-251.

Pross, J. 1997. Aquatische palynomorphe im Rupel des Mainzer Beckens (Oligozän, Südwestdeutschland): paläoökologie, biostratigraphie und taxonomie. Tübinger mikropaläontologische Mitteilung-, 15: $1-182$.

Sarjeant, W.A.S. 1970. The genus Spiniferites Mantell, 1850 (Dinophyceae). Grana, 10: 74-78.

Steininger, F.F., Aubry, M.P., Berggren, W.A. et al. 1997. The global stratotype section and point (GSSP) for the base of the Neogene. Episodes, 20: 23-28.

Strauss, C. \& Lund, J.J. 1992. A Middle Miocene dinoflagellate cyst microflora from Papendorf near Hamburg, Germany. Mitteilungen des Geologisch-Paläontologischen Instituts der Universität Hamburg, 73: $159-189$.

Strauss, C., Lund, J.J. \& Lund-Christensen, J. 2001. Miocene dinoflagellate cyst biostratigraphy of the Nieder Ochtenhausen research borehole (NW Germany). Geologisches Jahrbuch, Reihe A, 152: 395-447.

Torricelli, S. \& Biffi, U. 2001. Palynostratigraphy of the Numidian Flysch of northern Tunisia (Oligocene-Early Miocene). Palynology, 25: 29-55.

Vandenberghe, N., Brinkhuis, H. \& Steurbaut, E. 2003. The Eocene/ Oligocene boundary in the North Sea area: a sequence stratigraphic approach. In: Prothero, D.R., Ivany, L.C. \& Nesbitt, E.A. (Eds), From greenhouse to icehouse, the marine Eocene-Oligocene transition. Part III: The North Sea and Tethys. Columbia University Press, New York, 419-437.

Williams, G.L. \& Manum, S.B. 1999. Oligocene-Early Miocene dinocyst stratigraphy of Hole 985A (Norwegian Sea). In: Raymo, M.E., Jansen, E., Blum, P. \& Herbert, T.D. (Eds), Proceedings of the Ocean Drilling Program, Scientific Results, 162: 99-109.

Williams, G.L., Lentin, J.K. \& Fensome, R.A. 1998. The Lentin and Williams index of fossil dinoflagellates 1998 edition. American Association of Stratigraphic Palynologists, Contribution Series, 34: $1-817$.

Wilpshaar, M., Santarelli, A., Brinkhuis, H. \& Visscher, H. 1996. Dinoflagellate cysts and mid-Oligocene chronostratigraphy in the central Mediterranean region. Journal of the Geological Society, London, 153: 553-561.

Zachos, J.C., Pagani, M., Sloan, L.C., Thomas, E. \& Billups, K. 2001. Trends, rhythms and aberrations in global climate 65 Ma to present. Science, 292: 686-693.

Zevenboom, D. 1995. Dinoflagellate cysts from the Mediterranean Late Oligocene and Miocene. $\mathrm{PhD}$ thesis. University of Utrecht, The Netherlands.

Zevenboom, D. 1996. Late Oligocene-early Miocene dinoflagellate cysts from the Lemme-Carrosio section (NW Italy); biostratigraphy and palaeoenvironmental interpretation. Giornale di Geologia, Ser. 3a, 58: 81-93. 